\title{
WestVirginiaUniversity
}

THE RESEARCH REPOSITORY @ WVU

Graduate Theses, Dissertations, and Problem Reports

2008

\section{Agricultural awareness and perceptions of freshmen at West Virginia University}

Laura L. Pfeifer

West Virginia University

Follow this and additional works at: https://researchrepository.wvu.edu/etd

\section{Recommended Citation}

Pfeifer, Laura L., "Agricultural awareness and perceptions of freshmen at West Virginia University" (2008). Graduate Theses, Dissertations, and Problem Reports. 2639.

https://researchrepository.wvu.edu/etd/2639

This Thesis is protected by copyright and/or related rights. It has been brought to you by the The Research Repository @ WVU with permission from the rights-holder(s). You are free to use this Thesis in any way that is permitted by the copyright and related rights legislation that applies to your use. For other uses you must obtain permission from the rights-holder(s) directly, unless additional rights are indicated by a Creative Commons license in the record and/ or on the work itself. This Thesis has been accepted for inclusion in WVU Graduate Theses, Dissertations, and Problem Reports collection by an authorized administrator of The Research Repository @ WVU. For more information, please contact researchrepository@mail.wvu.edu. 
Agricultural Awareness and Perceptions of Freshmen at West Virginia University

\author{
Laura L. Pfeifer
}

Thesis submitted to the Davis College of Agriculture, Forestry, and Consumer Sciences at West Virginia University in partial fulfillment of the requirements

for the degree of

\author{
Master of Science \\ in \\ Agricultural and Extension Education
}

Harry N. Boone, Jr., Ph.D., Chair

Stacy A. Gartin, Ph.D.

Deborah A. Boone, Ph.D.

Robert A. Dailey, Ph.D.

Division of Resource Management

\author{
Morgantown, West Virginia \\ 2008
}

Keywords: agriculture, agricultural education, agricultural literacy, education 


\begin{abstract}
Agricultural Awareness and Perceptions of Freshmen at West Virginia University
\end{abstract}

Laura L. Pfeifer

Increased dependence on technology and further removal from agricultural practices has given rise to a decrease in agricultural literacy among members of society, which has established a need for advancement in educating individuals about the basic concepts of agriculture. This study was designed to determine the knowledge of agriculture possessed by incoming freshmen at West Virginia University (WVU). The data collected for this study were obtained from 403 freshmen participants who reported their responses to 35 Agricultural Knowledge, 35 Agricultural Perceptions, and 24 demographic statements and questions on an instrument administered during multiple First Year Orientation courses at WVU. It was revealed that all students lacked a good understanding of agriculture, but students with an agricultural background and who were enrolled in a major in the Davis College of Agriculture, Forestry, and Consumer Sciences were more knowledgeable about and possessed more positive perceptions of agriculture than their counterparts. 


\section{ACKNOWLEDGEMENTS}

"I lift up my eyes to the hills - where does my help come from? My help comes from the Lord, the Maker of heaven and earth" (Psalm 121:1-2). It is unreasonable to believe that I should have completed this project without the help of God. He blessed me with the gift of several wonderful people who unselfishly assisted in making my thesis a reality.

My graduate advisor and mentor, Dr. Harry N. Boone, Jr.: Your expertise and guidance most certainly turned an overwhelming process into an attainable reality. Thank you for your unconditional help and understanding.

My committee members, Dr. Stacy A. Gartin, Dr. Deborah A. Boone, and Dr. Robert A. Dailey: You each brought a unique gift to the table and I thank you for the opportunity to work those qualities into the overall success of my research.

Dr. Hillar Klandorf: Without your efforts, I would not have a population to study, any data to work with, and ultimately, a thesis to write. It has been a pleasure working with you and I thank you greatly for all your efforts.

My family, Richard and Rosemary Pfeifer, and Brinton, Jennifer, and Faith Ealy: There were times when I wanted to give up and take the easy road home, but you never once gave up on me; you encouraged me to do more than I ever thought I was capable of doing. Thank you for that, your prayers, and for your unconditional love.

Mr. Nicholas Carl Hornbeck: Through it all, you have unconditionally supported me, and more than once you have taken an active role in seeing that I accomplish my goals. I am truly blessed to have you in my life. Thank you for your love and patience. 
Despite a plethora of obstacles that arose throughout the writing of this research project, I always had a group of amazing supporters in my corner to give me hope. Your love, support, encouragement, and faith in my ability to accomplish that which I set out to is more greatly appreciated than you may ever know! This accomplishment is as much yours as it is mine. 


\section{TABLE OF CONTENTS}

ABSTRACT

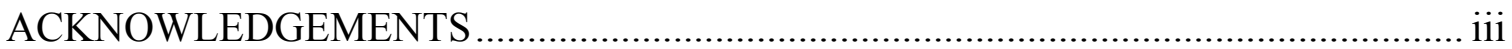

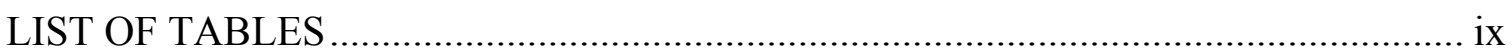

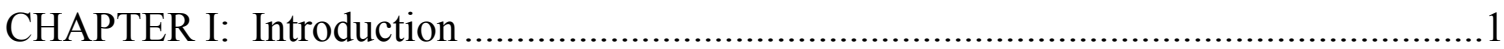

Statement of the Problem ........................................................................................

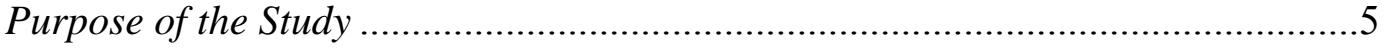

Objectives of the Study:......................................................................................

Definitions of Terms.......................................................................................

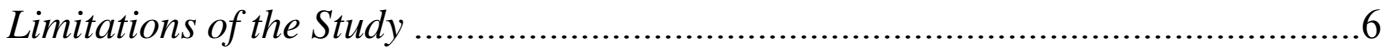

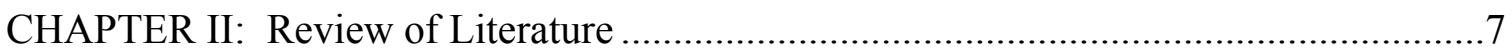

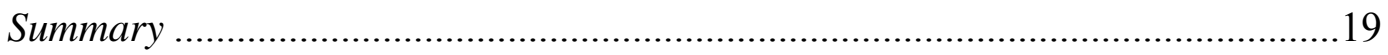

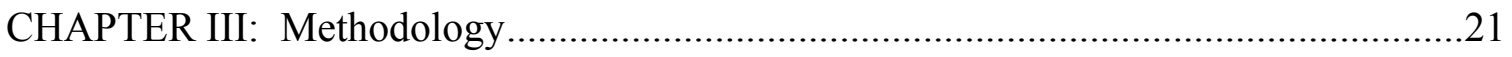

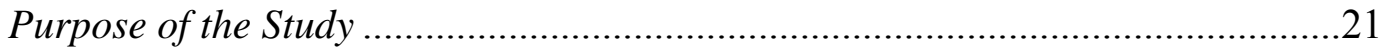

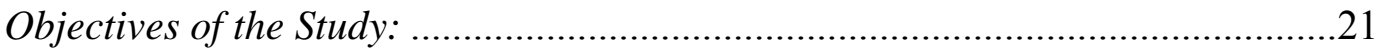

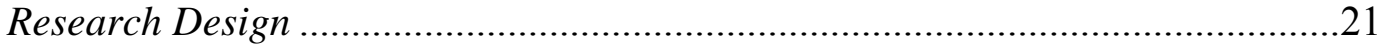

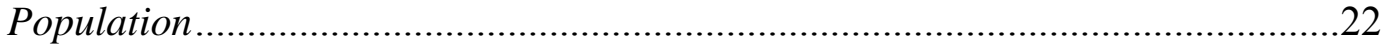

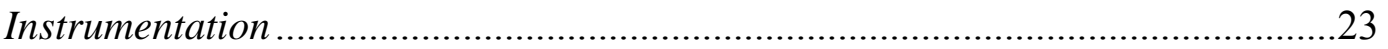

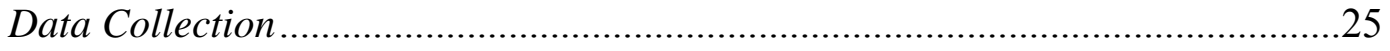

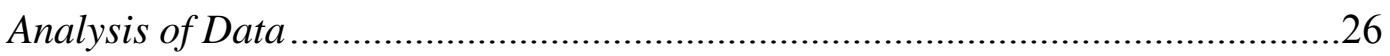

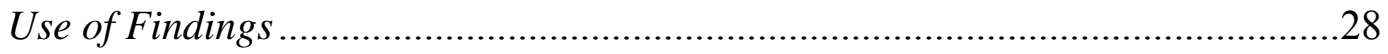

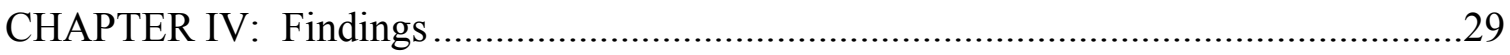

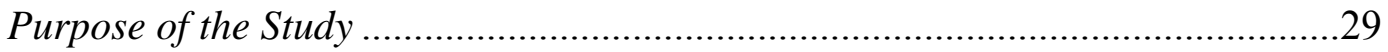

Objectives of the Study:.................................................................................29

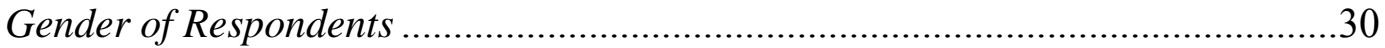




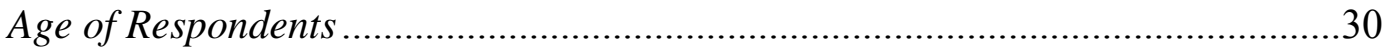

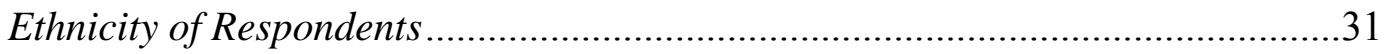

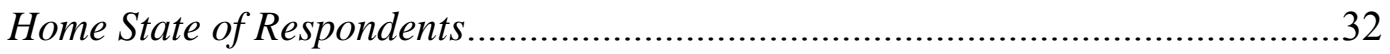

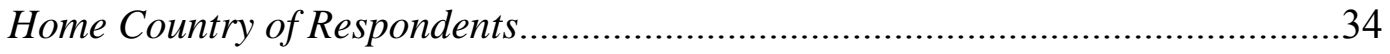

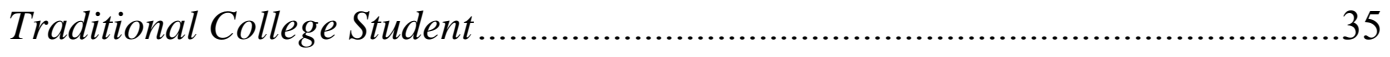

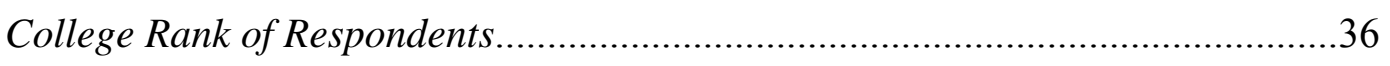

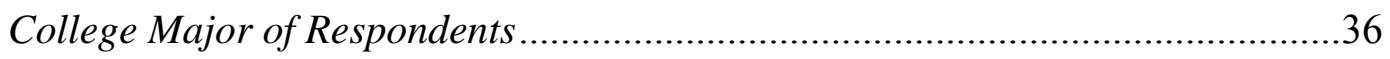

Classification of Home Geographical Location of Respondents ............................38

Agriculture-Related Work of Respondents..............................................................39

Agriculture-related Organizations Available to Respondents within their

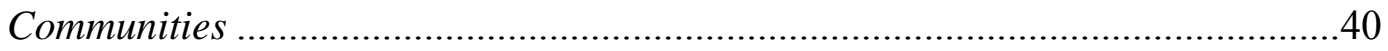

High School Agriculture Classes Taken by Respondents ....................................42

High School Offered Agriculture Education Courses ............................................42

Member of FFA, 4-H, and Other Agricultural Organization ...............................43

Involved in Agricultural Organization at West Virginia University.......................44

Definition of a Land Grant College by Respondents ............................................44

Knowledge of West Virginia University's Association to Agriculture by

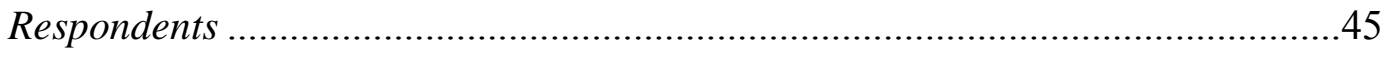

Analysis of Agricultural Literacy Statements .......................................................46

Responses to Agricultural Knowledge Statements...............................................47

General Agricultural Knowledge .....................................................................4

General Agricultural Knowledge Comparisons by Groups..................................54

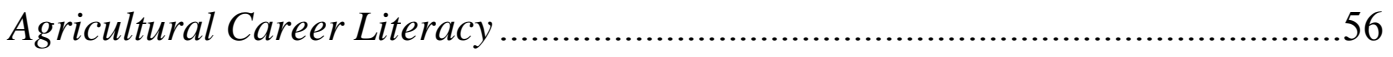

Agricultural Career Literacy Comparisons by Groups .........................................59

Agricultural Policy Literacy .............................................................................61

Agricultural Policy Literacy Comparisons by Groups ........................................66 
Environmental and Natural Resources Agricultural Literacy Comparison

by Groups

Overall Agricultural Literacy Scores...............................................................74

Agricultural Knowledge Perceptions...................................................................76

Agricultural Literacy Perception Scores ............................................................90

CHAPTER V: Summary, Conclusions, and Recommendations .......................................94

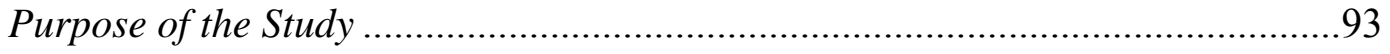

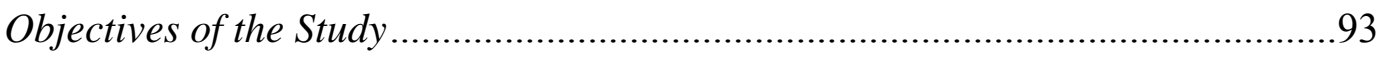

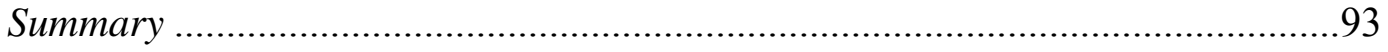

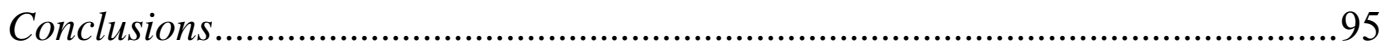

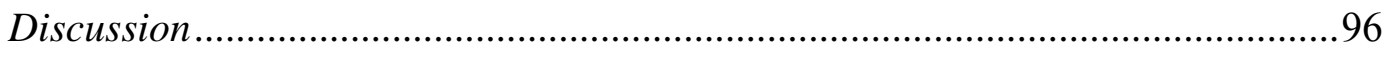

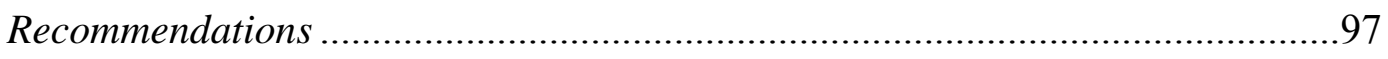

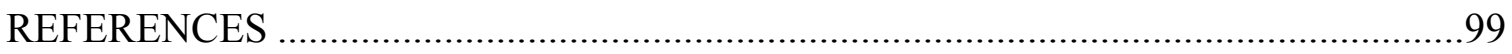

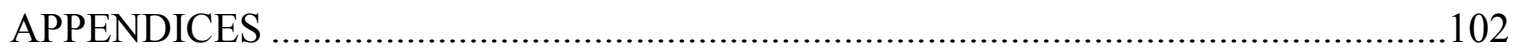

APPENDIX A: Email Correspondence with West Virginia University First Year Experience Orientation Instructors .....................................................................103

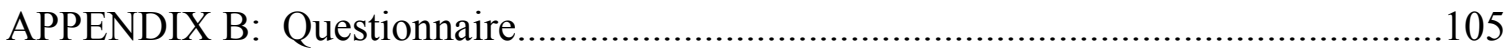

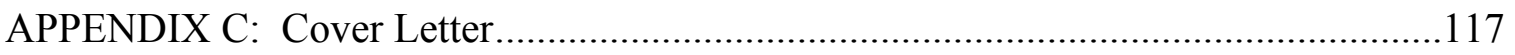

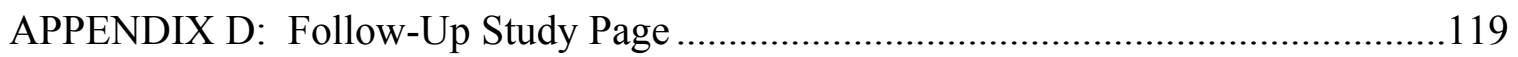

APPENDIX E: “Other" Ethnicities of Respondents ....................................................121

APPENDIX F: College Majors of Respondents........................................................123

APPENDIX G: Agriculture-Related Work Experience of Respondents .........................128

APPENDIX H: Agriculture-Related Organizations Available to Respondents in their Home Communities .................................................................................131

APPENDIX I: Respondent's Membership in Agriculture-Related Organizations..........133 
APPENDIX J: Respondent's Membership in Agriculture-Related Organizations at West Virginia University

APPENDIX K: Knowledge of West Virginia University's Status as a Land Grant University.

APPENDIX L: Knowledge of West Virginia University's Status as a Land Grant University 140

APPENDIX M: Knowledge of Other Land Grant University in West Virginia

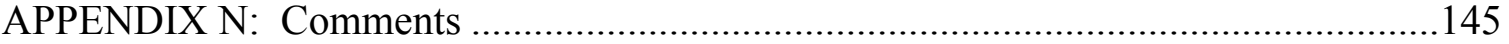

VITA 147 


\section{LIST OF TABLES}

Table Title

1 Gender of Respondents .30

Ethnicity of Respondents

Home State of Respondents

Home Country of Respondents

11 Agriculture-Related Organizations Available to Respondents within their Communities.

17 Knowledge of West Virginia University's Association to Agriculture by Respondents

18 Responses to Agricultural Knowledge Statements - General Agricultural Knowledge.

20 Responses to Agricultural Knowledge Statements - Agricultural 
22 Responses to Agricultural Knowledge Statements - Agricultural

Policy Literacy....

24 Responses to Agricultural Knowledge Statements - Environmental and Natural Resources Agricultural Literacy ...................................................71

25 Environmental and Natural Resources Agricultural Literacy Scores ...............74

$26 \quad$ Overall Agricultural Literacy Scores .........................................................76

27 Responses to Agricultural Perceptions Statements..........................................85

28 Agricultural Literacy Perceptions Scores …………………........................92 


\section{CHAPTER I}

\section{Introduction}

Throughout the last century, society has undergone a tremendous technological makeover from which today's agriculture has not been exempt. Advances in efficiency and productivity have resulted in less than two percent of the American population now providing the food and fiber on which to run the country (Womochil, 2007b). The wealth of such agricultural commodities has secured the United States' position as a leader in the world-wide market of food and fiber:

Robust global economic growth provides a foundation for gains in world demand for agricultural products. Rapid expansion of ethanol and biodiesel production in some countries also adds to the growth in global agricultural demand. The growing economies of developing countries are the main source of growth in world agricultural demand and trade. Food consumption and feed use are particularly responsive to income growth in those countries...(USDA ERC, 2008, np).

Such significant advances in technological practices have enabled agriculturists to produce more products using fewer resources, including land. A portion of this unused agricultural land has shifted to non-agricultural uses. A 1997 statistic showed an increase in the use of nearly 17 million acres of land in the United States for expansion of urban development (Vesterby \& Krupa, 1997). Agricultural land used for housing developments, shopping centers, and recreational facilities has affected rural and agricultural communities (Douglas, 1995). Non-agricultural uses of land shift the availability of land for the purposes of agricultural practices towards ever increasing urban dwellings in rural areas.

According to data collected by the U.S. Census Bureau in $2000,79 \%$ of the United States' population is located in an urban setting (this is listed in the references). 
The remaining $21 \%$ of the population located in rural settings are further broken down into those individuals who are farm or non-farm residents. Distinguishing between these two categories cannot be done due how the United States Department of Agriculture (USDA) collects and reports Census of Agriculture data. In West Virginia, the data are quite different. Fifty-four percent of the population in WV lives in rural settings, while $46 \%$ live in urban settings. "Much has changed since the formal program of agricultural education was implemented in 1917. Agriculture has changed, moving from 31 percent of the population living and working on farms to less than two percent" (Womochil, 2007b, p. 8).

The $98 \%$ of the American population not producing agricultural commodities depends on the ability of the other $2 \%$ to meet their demands. Despite the necessity for agricultural products, and the impact that they generate on the American and international economies, minimal exposure by the majority of society to general concepts concerning everyday agricultural relationships has become the norm (Birkenholz, 1992; Birkenholz, Harris, \& Pry, 1994; Frick, Birkenholz, \& Machtmes, 1996; Harris \& Birkenholz, 1996; Leising, 1998; Mawby, 1985; National Research Council, 1988; Raven, 1994; Womochil, 2007a; Womochil, 2007b). Within family structures and school systems, a lack of recognition, education, and implementation of agricultural knowledge is on the rise (Birkenholz, 1992; Birkenholz, Harris, \& Pry, 1994; Frick, Birkenholz, Gardner, \& Machtmes, 1995; Harris \& Birkenholz, 1996; Leising, 1998; National Research Council, 1988; Riedel, 2006; Webb, 1995; Womochil, 2007a ; Womochil, 2007b).

Few will argue that the current status of society's agricultural awareness and perceptions are in great need of attention. Russell G. Mawby of the W. K. Kellogg 
Foundation (1985) began the forward to Cultivating Agricultural Literacy: Challenge for the Liberal Arts with a statement about the rightful status of agriculture in today's society, stating that "Few issues are of greater importance to the world than adequate food supplies, proper food use, and knowledge about the components of the agricultural industry" (Mawby, 1985, p. 7). This idea of how important it is to have agriculturally knowledgeable members of society was identified and highlighted over twenty years ago, and little change has taken place. Yet policies concerning agriculture and agricultural production continue to thrive and require updating. If society has such little recognition and understanding of the basic concepts surrounding the agricultural industry, its ability to meet the needs and demands of producers and consumers is limited. When it comes down to it, from clothes and food to homes and vehicles, the number of areas where agriculture reaches is virtually limitless. Because agriculture plays such an important role in everyone's day-to-day lives, the average citizen should have an understanding of the agricultural industry and appreciation for the effects that various agricultural practices and policies have on their daily lives.

Despite the abundance of research implicating agriculturists as vital members of society, similar research has shown a trend toward less reliance on individual knowledge of agriculture and more dependence on that of the small fraction of those who make a living by it.

\section{Statement of the Problem}

Observing ever increasing changes in the abundance and availability of new technological practices while a dwindling effect appears in relation to the knowledge, appreciation, and comprehension of agricultural practices begs the question, has a 
technologically savvy society given rise to a decrease in agricultural literacy among its members?

Has society grown to depend so greatly on instant gratification that it can no longer develop a rationale for the processes that develop, prepare, and meet their everyday needs? In 20 or so years, will there be enough individuals fully knowledgeable and capable to provide for such demands, or more importantly the needs, of society? Has the education system failed students in preparing them with adequate knowledge about agricultural systems? The role of the agricultural education teacher, in part, is to convey to the students practical skills and sound knowledge of agricultural practices (Womochil, 2007a) as well as implementing other core curriculum such as English and math into these lessons. Yet, why is there little influence of agriculture being taught within these core classes? Research indicates a lack of agricultural knowledge among most school aged children, college students, and the general public, but what does this imply for the future of mankind in relation to the provision of necessary agricultural commodities (Birkenholz, 1992; Birkenholz, Harris, \& Pry, 1994; Frick, Birkenholz, Gardner, \& Machtmes, 1995; Harris \& Birkenholz, 1996; Leising, 1998; Mawby, 1985; National Research Council, 1988; Raven, 1994; Riedel, 2006; Webb, 1995; Womochil, 2007)? Will there be enough agriculturists in the future to meet the demands of society? Are there enough individuals within high ranking political positions who posses an adequate knowledge of agriculture to make appropriate decisions on agricultural policy issues? The concept for this study was to evaluate the current state of knowledge and perceptions of agriculture among college students and to provide further information to support continued agricultural literacy campaigns. 


\section{Purpose of the Study}

The purpose of this research study was to determine the knowledge of agriculture possessed by incoming freshmen at West Virginia University. Accessible first year students from all majors and colleges within West Virginia University completed a questionnaire, which assessed and provided data that illustrated their knowledge of general agricultural related topics.

Objectives of the Study:

The specific objectives of this study were as follows:

1) To assess the level of agricultural knowledge and perceptions possessed by incoming freshmen;

2) To compare the results of knowledge and perceptions possessed by students with an agricultural background to those students with no agricultural background; and

3) To assess and compare the level of knowledge and perceptions possessed by students as a collective body from non-agricultural colleges against those students from the agriculture college of West Virginia University.

\section{Definitions of Terms}

Agricultural awareness: an individual's level of agricultural literacy.

Agricultural literacy: an individual's comprehension of the food and fiber industry, which includes production, processing, distribution, and marketing, as well as an awareness of how agriculture impacts the environment, society, and daily living of that person (Webb, 1995).

Agricultural perceptions: an individual's opinions concerning the nature of the food and fiber industry. 


\section{Limitations of the Study}

This study was limited to freshmen enrolled as fulltime students in orientation classes at West Virginia University in Morgantown, WV during the Fall 2007 semester. Only those students who participated in completing the agricultural literacy test developed by Martin J. Frick and others were included in the results of this study. 


\section{CHAPTER II}

\section{Review of Literature}

Little debate exists as to whether or not society lacks an understanding of agriculture; research has confirmed that there is in fact a shortfall of agriculturally literate individuals within today’s society (Birkenholz, 1992; Birkenholz, Harris, \& Pry, 1994; Frick, Birkenholz, \& Machtmes, 1996; Frick, Birkenholz, Gardner, \& Machtmes, 1995; Harris \& Birkenholz, 1996; Leising, 1998; Mawby, 1985; National Research Council, 1988; Raven, 1994; Riedel, 2006; Webb, 1995; Womochil, 2007a; Womochil, 2007b). With an agricultural working class composed of less than two percent of the American population (Womochil, 2007a; Womochil, 2007b) and 79\% of the population living in urban settings (U.S. Census Bureau, 2008), it is evident that there has been a shift in society's relationship with agriculture.

This change in location of the population both geographically and in reference to current employment trends has in effect changed the way individuals have prioritized their lives. Once a popular high school course, vocational agriculture, more recently identified as agricultural education, has seen a reduction in student enrollment numbers (Rossetti \& McCaslin, 1991).

Little to no information is available for identifying a rational number of students enrolled in agricultural education courses. However, according to the 2005-2006 Annual Report on Agricultural Education published by Team Ag Ed, 7,242 active FFA chapters were reported. An average of 68 students belonged to each chapter, resulting in approximately 500,000 student members of the National FFA Organization. All members of the FFA program are required to be enrolled in an agricultural education 
course, so it is evident that there are a minimum of one-half million students participating in such courses. According to the National Center for Education Statistics (NCES), approximately $15,000,0009^{\text {th }}-12^{\text {th }}$ grade students enrolled in public schools during the 2005-2006 academic school year, making up the majority of grades for which students participate in the FFA program and agricultural education courses (NCES, 2005-06). These statistics identify a large gap between the total number of students in the school system and those students who actively participate in agricultural education courses that increase their exposure to agriculture.

Despite a common theme tending towards decreased agricultural education enrollment, student enrollment in middle school FFA programs in 1991 was estimated at nearly 53,000 (Rossetti \& McCaslin, 1991). In only three years (the National FFA Organization passed an amendment to their constitution in 1988 allowing middle school aged students to gain membership to the program), the enrollment of students in FFA grew from 401,000 students during the 1991-1992 school year to 417,000 students the following year. This admittance of middle school students into the agricultural education program was "beneficial to the students..." who "were more aware about agriculture and more informed about careers in agriculture" (Rossetti \& McCaslin, 1991, p.26).

A study conducted by Riedel (2006) using North Carolina urban schools evaluated the effects of an introductory agricultural education course on the agricultural literacy and perceptions of students enrolled in the course. Riedel investigated the level of success achieved by students who participated in an agriscience applications class with respect to agricultural literacy and their knowledge of agricultural careers and opportunities for employment, agriculture's relationship with public policy, and 
agriculture's relationship with the environment and natural resources, as well as student's perceptions of the food and fiber industry. The results indicated a general increase in the student's scores upon completion of the course, but the post-test scores reflected an overall lack of literacy relating to agriculture as compared to national standards. Riedel's conclusion reflected "a need for agriculturally literate citizens and more importantly a means to educate today's students and tomorrow's society" (Riedel, 2006, p. 53).

The idea of agricultural literacy was developed as a result of findings from the study conducted by the National Research Council, Board on Agriculture, Committee on Agricultural Education in Secondary Schools. In Understanding Agriculture: New Directions for Education (1988), the National Research Council published its working definition of agricultural literacy.

....an agriculturally literate person's understanding of the food and fiber system would include its history and its current economic, social, and environmental significance to all Americans. This definition is purposely broad, and encompasses some knowledge of food and fiber production, processing, and domestic and international marketing. As a compliment to instruction in other academic subjects, it also includes enough knowledge of nutrition to make informed personal choices about diet and health. Agriculturally literate people would have the practical knowledge needed to care for their outdoor environments, which include lawns, gardens, recreational areas, and parks. (National Research Council, 1988, p. 8-9)

The basis for this definition stemmed from major findings of the report stating that "Agricultural education in U.S. high schools does not extend beyond the offering of a vocational agriculture program" (National Research Council, 1988, p. 2). With such a strong statement indicating a lack of education referencing agriculture throughout all school systems, the Council's recommendations included changing the focus of agricultural education and "Beginning in kindergarten and continuing through twelfth 
grade, all students should receive some systematic instruction about agriculture"

(National Research Council, 1988, p. 2). Despite these findings, the Council (1988) also identified a positive correlation between students enrolled in vocational agriculture programs and their development of practical skills, self-confidence, and leadership abilities.

In his 1990 delphi study of important agricultural concepts necessary for individuals to possess acceptable literacy of agriculture, Martin J. Frick established a definition of agricultural literacy as perceived by professionals in varying agriculturerelated fields. Eleven broad areas of agriculture were identified from which a vast number of more specific concepts concerning each broad category were also established.

Frick summarized the categories and developed the definition of agricultural literacy as, ... understanding and possessing a knowledge of our food and fiber system. An individual possessing such knowledge would be able to synthesize, analyze, and communicate basic information about agriculture. Basic agricultural knowledge includes: the production of plant and animal products (divided into separate concept areas in the concept questionnaire), the economic impact of agriculture, its societal significance, agriculture's important relationship with natural resources and the environment (divided into separate concept areas in the concept questionnaire), the marketing and processing of agricultural products, public agricultural policies, the global significance of agriculture, and the distribution of agricultural products. (Frick, 1990, p. 41)

To avoid confusion about the depth to which individuals should be agriculturally literate, Frick, Birkenholz, Gardner, \& Machtmes (1995) noted that, "Functional agricultural literacy does not imply a perfect level of understanding about agriculture, but rather a minimum level” (p. 2).

There has always been a strong connection between agricultural education and the workings of Land Grant Universities, as the later were established in response to the 
Land Grant College Act of 1862, better known as the First Morill Act. It was through this congressional act that the mission "to teach agriculture, military tactics, and the mechanic arts as well as classical studies so that members of the working classes could obtain a liberal, practical education" (WVU Extension Service, 1999, np) was established. Benefited by the Hatch Act of 1887, the second Morill Act of 1890, and the Smith-Lever Act of 1914 in which funds were provided for research in agriculture, monies were distributed to those universities not discriminating against admitting students of races outside of the white population or to establish additional colleges for black students, and development of the Cooperative Extension Service, respectively, the land grant university system has exerted a great influence on the agricultural education system. With the majority of agricultural educators receiving instruction from land grant universities, as well as research conducted in such facilities leading to subject matter implemented in the classroom, it is evident that Land Grant Universities provide immeasurable resources for educating individuals about agriculturally relevant material.

A momentous report by the National Research Council (1988) addresses the significant lack of agricultural knowledge possessed by the majority of Americans. This knowledge is reflective of basic concepts of agriculture, including "its social and economical significance in the United States," and "its links to human health and environmental quality" (National Research Council, 1988, p. 9). In other words, the report illustrates that not only is agriculture relevant to those immediately exposed to it, but every individual who depends on food, fiber, and other basic necessities to sustain their life. In addition, the report acknowledges that "Few systematic educational efforts are made to teach or otherwise develop agricultural literacy in students of any age," and 
even when attempts are made to implement agriculture into the context of the class courses, "the material tends to be fragmented, frequently outdated, usually only farm oriented, and often negative or condescending in tone" (National Research Council, 1988, p. 9).

Much consideration has been given to developing fundamental ways in which agricultural literacy can be increased in all citizens. A work group of individuals, under the direction of R. J. Birkenholz, developed Strategies to Promote Agricultural Literacy in which they identified and discussed the agricultural literacy issues concerning Americans in today's society as well as described recommendations for alleviating the current poor conditions reflecting the lack of agricultural literacy of the general public. Among a wide variety of other alternatives, the Agricultural Literacy Work Group discussed the idea that "Teachers in elementary and secondary schools should also be encouraged (possibly required) to develop a greater understanding of the importance of agriculture to all people" (Birkenholz, 1992, p. 15). In reference to students enrolled in post-secondary education, the Work Group suggested that:

College students, especially those attending land-grant institutions, should be required to develop an awareness of and appreciation for agriculture prior to their graduation from any degree program. Graduates of higher education institutions should not be viewed as 'fully educated' if they lack an awareness of the importance of agriculture in their daily lives.

(Birkenholz, 1992, p. 16)

In the October 2007 issue of FFA Advisors Making a Difference, a new proposal presented by Team Ag Ed, known as the 10 X 15 initiative, was the main focus of discussion. In part, the initiative states that "By 2015 there will be in operation 10,000 quality agricultural science education programs serving students through an integrated model of classroom/laboratory instruction, experiential learning, and leadership and 
personal skill development" (Womochil, 2007a, p.1). The current USDA statistics identify that " 17 percent of the domestic workforce is engaged in more than 300 agriculture career areas" yet "agricultural education is not serving 17 percent of the student population, but rather about 6 percent..." (Womochil, 2007b, p.7). When looking at these statistics and comparing them to the ideal goal to be reached by 2015 , it is apparent that something must change in order to facilitate a higher enrollment of students in agricultural education courses to provide the expected number of educators with employment opportunities. In addition, influencing students to enroll in higher education courses and becoming agricultural educators is necessary. Ultimately, if students are to acquire knowledge concerning agriculture and, therefore increase their agricultural literacy levels, a significant change in education must occur.

The 1994 study of agricultural literacy among college students by Birkenholz, Harris, \& Pry assessed their level of knowledge relating to agriculture and suggested that despite an overall knowledge of agriculture and positive perceptions concerning agriculture, several variables influenced those individuals whose agricultural literacy levels were higher. Students who had family members living on a farm, and raised crops or gardens were the most knowledgeable about agriculture, while college students living in closer proximity to highly developed geographical locations were less knowledgeable about agriculture. Their recommendations to alleviate such situations among college students include providing students with farm experience as well as implementing agricultural education programs throughout elementary, secondary, and higher education courses (Birkenholz, Harris, \& Pry, 1994). 
In a study of agriculture literacy among high school students, it was identified that "Rural High School Students respondents had significantly higher knowledge concept scores than Urban Inner-City High School respondents in all of the seven areas," but only significantly higher perceptions concerning "the animal and plant areas" (Frick et al., 1995, p. 7). As a result, their recommendations concerning the identification of agricultural literacy among a specified group "be first directed to address the agricultural knowledge that the targeted audience does not know rather than verifying the agricultural knowledge they do know" (Frick et al., 1995, p. 8). In an additional study conducted by Frick, Birkenholz, \& Machtmes (1995), knowledge and perceptions of agriculture possessed by rural and urban adults were identified using the same/similar instrument. Their conclusions indicated that "Respondents living on farms were more knowledgeable about agriculture than their rural non-farm neighbors, who were more knowledgeable than their urban counterparts" and "Both respondents groups had relatively positive perceptions of agriculture" (Frick, Birkenholz, \& Machtmes, 1996, p. 51). However, further investigation into developing programs that would enhance the agricultural literacy of all individuals was strongly recommended by the researchers (Frick, Birkenholz, \& Machtmes, 1996).

In 1995, Webb conducted a study addressing the issue of Agricultural Knowledge of Entering Agriculture Majors at Potomac State College and West Virginia University. Using a 100 question test developed by random selection of questions from the West Virginia Department of Education completer competency tests in agriculture-related courses, Webb made several conclusions related to agricultural literacy based on the results of 55 students from two West Virginia schools of higher education. It was noted 
that "freshmen students enrolled in agricultural curricula...have limited knowledge of agriculture" and "Students who have taken agriculture in high school have only slightly more knowledge than those who did not take high school agriculture" (Webb, 1995, p. 33). However, Webb identified those students who participated in agriculture classes in high school, had a "farm background and agricultural related employment," and had "prior agricultural related experiences" were more positively influenced as to the development of their agricultural knowledge (Webb, 1995, p. 33). Her overall conclusion reflected a need for increased agricultural education for students as well as educators.

If educators at all levels are expected to implement agricultural knowledge into their curricula, they must first have working knowledge and an understanding of the concepts of agriculture. In order that the material taught by teachers be accurate and effective, resources for educating them must be made available. However, among educators there is a vast range of levels of agricultural literacy and perceptions which must first be assessed before developing and implementing programs for educating teachers. Even so, it is paramount that all educators, regardless of content area taught, make the connection "to agriculture and...provide a context for infusing instruction about agriculture" (Harris \& Birkenholz, 1996, p. 64) into their course content. Harris \& Birkenholz (1996) addressed this issue of teacher related agricultural literacy. Their findings indicated that those respondents who participated in the study (mostly associated with schools which offered courses in agricultural education) possessed some level of knowledge and positive perceptions toward agriculture. This study, specifically associated with its relatively inconclusive results, emphasizes the need for education relative to agriculture at all levels, including youth as well as adults. 
The reoccurring theme that all investigations into agricultural literacy address is that there is a lack of knowledge about agriculture among the majority of society, including our educators, which in effect generates a cyclical problem. "Many people have a narrow and antiquated perception of agriculture," (Leising, 1998, np) leaving it difficult for them to make connections between the current practices of agriculture and ways in which these ideas can be incorporated into the current educational curricula. Despite the lack of knowledge most teachers outside of agricultural education possess, most teachers are willing to learn about agriculture and utilize the knowledge they gain as a source of information to be implemented into their classroom lessons and procedures (Bellah \& Dyer, 2007).

Whether an individual plans to follow a career path directly or indirectly associated with agriculture, the simple fact remains that there is no way to escape the influence that agriculture has on everyone's life. "Agriculture is too important a topic to be taught only to the relatively small percentage of students considering careers in agriculture and pursuing vocational agriculture studies" (National Research Council, 1988, p. 1). Consuming food, wearing clothes, living in a home made with wood studs, and participating in any outdoor recreational activity are only a few examples of how agriculture and its products and byproducts directly affect every individual's life. Public policies developed and implemented in the United States, which affect both agriculturists and non-agriculturists alike, often produce negative impacts on the production of food and fiber products (Raven, 1994). Much of this is a result of individual's lack of knowledge of the food and fiber production systems. "Yet today most people, including 
those in key positions of public decision-making, do not understand the complexities of America's food system..." (Mawby, 1985, p. 7).

Continued efforts to further agricultural literacy depend on investigating the current status of agriculturally literate individuals and groups, which Doerfert (2003) has noted to be a job well done by researchers in agricultural education. Doerfert's main point of concern, however, is the lack of research done to evaluate the most beneficial courses of action in which the most significant results leading to an increase in agricultural literacy are obtained.

Strides toward educating individuals about agriculture do exist in a variety of forms. Programs such as Ag in the Classroom and Food for America are geared toward educating youth at the elementary level. Extension Services provide programs dealing directly with agricultural related issues to members of the community. Places such as the Slate Run Living Historical Farm in Westerville, OH, Meadowcroft Rockshelter and Museum of Rural Life in Avella, PA, and New Jersey Museum of Agriculture in New Brunswick, NJ are examples of only a minute percent of available hands-on resources for individuals to experience rural living as it was done hundreds of years ago. A simple Internet search for agriculture-related resources produces millions of results. However, with all of these available resources, little is done to directly influence and educate the common public, and more specifically policy makers, whose decisions decide the fate of agricultural practices, not to mention those programs developed to educate individuals about the agricultural practices (Raven, 1994).

It is a well known concept that beginning education at an early age benefits the capacity an individual has for retaining and comprehending the information. In 
connection to this idea, educating young individuals about agriculture may establish an early understanding and acceptance of agricultural issues (Blackburn, 1999). "Educational philosophers such as Socrates, Aristotle, Pestalozzi, Rousseau, Comenius and Benjamin Franklin all recognized the value of a child's learning about agriculture" (Blackburn, 1999, np). Programs such as Ag Science Fairs and elementary school gardens have proven to be valuable tools for increasing agricultural literacy among young children (Blackburn, 1999; Camp, 2004).

The USDA recently conducted a study that analyzed the impact of the Ag in the Classroom program, developed in 1981 by the USDA to incorporate agricultural issues into general classes such as math, science, history, English, and other courses. The findings of the study, which was conducted at the elementary school level (grades Kindergarten through sixth) in classrooms whose teachers had received training in agriculture by Ag in the Classroom (AITC), illustrated the benefits of performing such additions to the classroom curriculum. The findings concluded that even though all of the students displayed some knowledge of agriculture prior to learning from the instructor, those students who received education from AITC trained teachers more effectively learned the information and were ultimately more knowledgeable about agriculture than those students who were taught by an instructor who had not received training from AITC (Leising, Pense, \& Portillo, 2003).

The theme of the July-August edition of The Agricultural Education Magazine focused around literacy in agriculture, specifically, “Achieving 2020: Goal 3: All students are conversationally literate in agriculture, food, fiber, and natural resource systems" (Moore, 2000, np). As the mission of The National Strategic Plan and Action 
Agenda for Agricultural Education states, "Agricultural education prepares students for successful careers and a lifetime of informed choices in the global agriculture, food, fiber and natural resources systems" (Team Ag Ed, 2000, np). A national revamping of the agricultural education system is the goal of this initiative. Discussion in this specific issue highlighted many of the common themes addressing agricultural literacy, including grasping the concept of the idea of such a term, associations which aid in educating and promoting education for youth about agriculture, the lack of agricultural literacy exhibited by students across the nation's school systems, implementing agricultural education into the general classroom setting, and preparing future educators with the agricultural knowledge they need for the classroom. As the magazine theme illustrates, all of the discussions focused on the main concept that there is a lack of knowledge among our youth, our young adults, adults, and even individuals in the education system and highly influential policy makers.

Research supports the concept that a substantial change in agricultural awareness and perceptions among functioning individuals in today's society must be achieved so as to ensure a positive outlook for the agricultural industry. Denying or ignoring the current agricultural literacy situation will do no more than strengthen the agriculturally illiterate.

\section{Summary}

Today's society is now further removed from agriculture than ever before. Technology has significantly influenced a trend leading individuals in greater numbers toward urban settings and away from the farm.

With this disconnect between society and agricultural life, individuals more frequently fail to gain knowledge about the workings and concepts of agriculture. Policy 
makers and educators are amongst those lacking such knowledge, in turn leading to deficient policies for agriculturists and minimal education of America's youth. In short, there is an increasing lack of agricultural knowledge among citizens; agricultural illiteracy is on the rise. 


\section{CHAPTER III}

\section{Methodology}

\section{Purpose of the Study}

The purpose of this research study was to determine the knowledge of agriculture possessed by incoming freshmen at West Virginia University. Accessible first year students from all majors and colleges within West Virginia University completed a questionnaire which assessed and provided data that illustrated their knowledge of general agricultural related topics.

\section{Objectives of the Study:}

The specific objectives of this study were as follows:

1) To assess the level of agricultural knowledge and perceptions possessed by incoming freshmen;

2) To compare the results of knowledge and perceptions possessed by students with an agricultural background to those students with no agricultural background; and

3) To assess and compare the level of knowledge and perceptions possessed by students as a collective body from non-agricultural colleges against those students from the agriculture college of West Virginia University.

\section{Research Design}

A descriptive research design was selected as the method for this study. The objective of using descriptive research is to allow the researcher the opportunity to make generalizations about different groups based on the data collected from the sample population while also assessing their attitudes and perceptions in regard to a specific issue. In addition, it allows for more variety in the range of information to be collected, a 
larger population from which to collect data, the ability to address actual circumstances, and identifying more detailed problems. Those disadvantages associated with this type of research include the collection of unnecessary responses, being costly in both time and money, and lacking external validity and the collection of valid data. (Ary, D., Jacobs, L.

C., Razavieh, A., \& Sorensen, C., 2006).

\section{Population}

The target population of this study was all 4,731 incoming college freshmen at West Virginia University (WVU) in Morgantown, WV enrolled during the 2007 fall semester. The target population consisted of $51 \%$ male and $49 \%$ female students, $57 \%$ of which represented all 55 counties from West Virginia, and 49 states, the District of Columbia, 2 Territories (Puerto Rico and Virgin Islands) and 99 Nations were also represented in the population. Seven percent of the target population were identified as minorities.

All entering freshmen are required by University policy to participate in a First Year Experience course. Due to University policy, a complete list of incoming freshmen students as well as a list of all scheduled First Year Experience courses was not available to the researcher. This made a census of incoming freshmen possible by using the listing of scheduled First Year Experience courses posted on WVU's course registration page. A purposeful sample was self selected as instructors of these courses were contacted via email and asked for their permission and cooperation in distributing the questionnaire to the students present during their scheduled class times. Only those students of instructors who responded and allowed their students to participate were included in the study. The 
accessible population was 417 incoming freshmen who participated in a First Year Experience course during the 2007 fall semester at West Virginia University.

\section{Instrumentation}

The instrument for this study was a questionnaire consisting mainly of questions obtained from a previous study performed by Riedel in 2006 as well as one in 1995 by Fritz, Birkenholz, Gardner, and Machtmes. These instruments were used to measure the agricultural knowledge and perceptions of high school students. The researcher gained permission to use the instrument in their study by contacting Martin J. Frick, co-author of the 1995 study. Only a small portion of the demographic questions in the questionnaire were used from the original survey. The majority of the demographic questions in the survey were developed by the researcher (see Appendix B).

The instrument consisted of three main sections which included agricultural knowledge, perceptions, and demographics. The agricultural knowledge questions covered areas of general agricultural knowledge, agricultural career literacy, agricultural policy literacy, and environmental and natural resources agricultural literacy.

Respondents were instructed to select two answers for each of the 35 agricultural knowledge statements. If they believed the statement to be true, they were to circle "T," or if they believed the statement to be false, they were to circle "F." Based on their level of confidence in their answer, respondents were also instructed to circle " $\mathrm{S}$ " if they were sure their response was correct or "U" if they were unsure of their response.

The perceptions section of the questionnaire consisted of 35 statements for which respondents were asked to rate their opinion by using a Likert scale. Respondents were instructed to circle the letter that most accurately corresponded to their opinion on the 
scale which ranged from Strongly Agree (SA) to Agree (A) to Neutral (N) to Disagree (D) to Strongly Disagree (SD).

The demographics section was developed using questions designed to enable the researcher to make comparisons among the respondents as well as inform the researcher of potential background information on respondents pertaining to agricultural exposure. Demographic questions included information about the respondent's gender, age, ethnicity, home location, education status, individual's and relative's work experience on a farm and in an agricultural business, participation in and availability of agricultural courses and organizations in high school and college, and knowledge of Land Grant Universities and WVU's farms.

An additional portion of the questionnaire included a separate sheet for respondents to remove and fill out if they desired to participate in a potential follow-up study. The form asked for their name, permanent address, and primary email address and phone numbers, as well as any comments regarding the questionnaire so that they could be contacted in the future should a follow-up study to this study take place (see Appendix C).

The validity and reliability of the original instrument was established (Frick et al., 1996; Riedel, 2006). A Kr-20 score of 0.85 was found, indicating that the Overall Agricultural Knowledge statements in the original instrument were reliable. A Chronbach's alpha coefficient score of 0.90 was found for the Agricultural Literacy Perceptions statement. In order to determine the validity of the statements, the instrument was presented to a national panel of experts in agricultural literacy for review. 
The instrument was determined to be a valid tool for assessing agricultural literacy and perceptions of high school students (Frick, et.al., 1995).

In order to avoid measurement error, the content and face validity of the current instrument used in this study was presented to a panel of experts from West Virginia University consisting of faculty members with extensive professional, teaching, and research in agriculture and deemed valid for use in measuring concepts relative to agricultural literacy. The instrument was deemed valid.

The total data set was used to establish the instrument's reliability for the population of WVU freshmen students. The questionnaire was divided into three segments and the split-half statistical procedure was used to establish their reliability. The segments included agricultural knowledge answer, agricultural knowledge certainty, and perceptions. The reliability of the three portions: agricultural knowledge answer, agricultural knowledge certainty, and perceptions was found to be exemplary at 0.79 , 0.96, and 0.41 respectively (Robinson, Shaver, \& Wrightsman, 1991).

\section{Data Collection}

Each participating instructor was contacted via email to establish the location, time, and day for implementing the questionnaire to the students in their class(es). The researcher attended the scheduled classes where a cover letter (see Appendix D) was distributed to each student and the letter was read to the group. The letter described the nature of the study and emphasized voluntary participation and the need for accurate responses. The researcher then distributed the questionnaires and instructed the students to carefully read through the directions to each of the three sections of the questionnaire. Once students completed the questionnaire, they removed the single sheet of paper which 
was used to gather a list of respondents for a possible future study of agricultural literacy and placed it in a pile on the front desk. They placed the questionnaire in a separate pile. Due to the nature of how the data were collected, in a classroom setting with respondents present, there was no need to perform statistical tests to compensate for non-response error or late respondents.

\section{Analysis of Data}

No identification numbers were used to identify respondents. However, as the data from each questionnaire were transferred from the paper copy to an electronic copy, a number was placed on the front side of the questionnaire in order that it might be traced to the original instrument during data analysis. The data were coded and entered into an Excel $^{\circledR}$ file, which was then used in an SPSS program for statistical evaluation. Depending on the type of data gathered, different types of statistical analyses were performed.

The first two sections of the instrument included Agricultural Knowledge and Agricultural Literacy Perception statements. Descriptive statistics, including measures of central tendency and variability, were used to describe the 70 statements in these sections. The demographic data collected in the third portion of the instrument were also analyzed using descriptive statistics.

During the second phase of the data analysis, the false responses among the 35 true and false statements were reverse coded. Statements which reflected inaccurate perceptions of agriculture from the perceptions portion of the instrument were also reverse coded. The 403 respondents were categorized into Davis College/Non-Davis College and Agricultural Background/Non-Agricultural Background respondent groups. 
Independent $t$-tests were used to compare Davis and non-Davis students, as well as students with an agricultural background and students without an agricultural background, on overall Agricultural Knowledge (OAK), General Agricultural Knowledge (GAK), Agricultural Career Literacy (ACL), Agricultural Policy Literacy (APL), Environmental and Natural Resources Agricultural Literacy (ENRAL), and Agricultural Literacy Perceptions (ALP). Hypotheses developed for the statistical comparison of these groups included:

$$
\begin{aligned}
& \mathrm{H}_{0}=M_{\text {Davis College OAK }}=M_{\text {Non-Davis College OAK }} \\
& \mathrm{H}_{1}=M_{\text {Davis College OAK }} \neq M_{\text {Non-Davis College OAK }} \\
& \mathrm{H}_{0}=M_{\text {Agricultural Background OAK }}=M_{\text {Non-Agricultural Background OAK }} \\
& \mathrm{H}_{1}=M_{\text {Agricultural Background OAK }} \neq M_{\text {Non-Agricultural Background OAK }} \\
& \mathrm{H}_{0}=M_{\text {Davis College GAK }}=M_{\text {Non-Davis College GAK }} \\
& \mathrm{H}_{1}=M_{\text {Davis College GAK }} \neq M_{\text {Non-Davis College GAK }} \\
& \mathrm{H}_{0}=M_{\text {Agricultural Background GAK }}=M_{\text {Non-Agricultural Background GAK }} \\
& \mathrm{H}_{1}=M_{\text {Agricultural Background GAK }} \neq M_{\text {Non-Agricultural Background GAK }} \text {; } \\
& \mathrm{H}_{0}=M_{\text {Davis College ACL }}=M_{\text {Non-Davis College ACL }} \\
& \mathrm{H}_{1}=M_{\text {Davis College ACL }} \neq M_{\text {Non-Davis College ACL }} \\
& \mathrm{H}_{0}=M_{\text {Agricultural Background ACL }}=M_{\text {Non-Agricultural Background ACL }} \\
& \mathrm{H}_{1}=M_{\text {Agricultural Background ACL }} \neq M_{\text {Non-Agricultural Background ACL }} \\
& \mathrm{H}_{0}=M_{\text {Davis College APL }}=M_{\text {Non-Davis College APL }} \\
& \mathrm{H}_{1}=M_{\text {Davis College APL }} \neq M_{\text {Non-Davis College APL }} \\
& \mathrm{H}_{0}=M_{\text {Agricultural Background APL }}=M_{\text {Non-Agricultural Background APL }} \\
& \mathrm{H}_{1}=M_{\text {Agricultural Background APL }} \neq M_{\text {Non-Agricultural Background APL }}
\end{aligned}
$$




$$
\begin{aligned}
& \mathrm{H}_{0}=M_{\text {Davis College ENRAL }}=M_{\text {Non-Davis College ENRAL }} \\
& \mathrm{H}_{1}=M_{\text {Davis College ENRAL }} \neq M_{\text {Non-Davis College ENRAL }} \\
& \mathrm{H}_{0}=M_{\text {Agricultural Background ENRAL }}=M_{\text {Non-Agricultural Background ENRAL }} \\
& \mathrm{H}_{1}=M_{\text {Agricultural Background ENRAL }} \neq M_{\text {Non-Agricultural Background ENRAL }} \\
& \mathrm{H}_{0}=M_{\text {Davis College ALP }}=M_{\text {Non-Davis College ALP }} \\
& \mathrm{H}_{1}=M_{\text {Davis College ALP }} \neq M_{\text {Non-Davis College ALP }} \\
& \mathrm{H}_{0}=M_{\text {Agricultural Background ALP }}=M_{\text {Non-Agricultural Background ALP }} \\
& \mathrm{H}_{1}=M_{\text {Agricultural Background ALP }} \neq M_{\text {Non-Agricultural Background ALP. }}
\end{aligned}
$$

\section{Use of Findings}

The findings of this research project will be compared to those of Riedel (2006) and Frick et al. (1995) to further the identification of agricultural literacy issues. In addition, an awareness of how knowledgeable students are about agriculture will enhance the instruction of agriculture-related topics at the elementary, middle, and high school levels. 


\section{CHAPTER IV}

\section{Findings}

\section{Purpose of the Study}

The purpose of this research study was to determine the knowledge of agriculture possessed by incoming freshmen at West Virginia University (WVU). Accessible first year students from all majors and colleges within West Virginia University completed a questionnaire which assessed and provided data that illustrated their knowledge of general agricultural related topics.

\section{Objectives of the Study:}

This study was implemented to evaluate agricultural awareness and perceptions of freshmen at WVU while considering the influence of agricultural experiences prior to attending college. Agricultural literacy of students enrolled in the Davis College of Agriculture, Forestry and Consumer Sciences at WVU was compared to the level of agricultural literacy possessed by students enrolled in all other WVU colleges. Areas of interest concerning agricultural knowledge which were evaluated using an agricultural literacy test included general agricultural knowledge, agricultural career literacy, agricultural policy literacy, and environmental and natural resources agricultural literacy. The specific objectives of this study were as follows:

1) To assess the level of agricultural knowledge and perceptions possessed by incoming freshmen;

2) To compare the results of knowledge and perceptions possessed by students with an agricultural background to those students with no agricultural background; and 
3) To assess and compare the level of knowledge and perceptions possessed by students as a collective body from non-agricultural colleges against those students from the agriculture college of West Virginia University.

The accessible population consisted of 417 freshmen students at West Virginia University during the Fall 2007 semester. Four hundred three useable questionnaires were analyzed.

\section{Gender of Respondents}

Respondents were asked to identify their gender. Female respondents included $216(53.6 \%)$ individuals while $186(46.2 \%)$ respondents were male. One $(0.2 \%)$ respondent did not identify their gender (see Table 1).

Table 1

Gender of Respondents

\begin{tabular}{lcc}
\hline & $\mathrm{N}$ & $\%$ \\
\hline Female & 216 & 53.6 \\
Male & 186 & 46.2 \\
No Response & 1 & .2 \\
\hline
\end{tabular}

\section{Age of Respondents}

Respondents were asked to identify their age using four categories. Thirty-three $(8.2 \%)$ respondents identified their age to be less than 18 years. Three hundred forty-six $(85.9 \%)$ of the respondents listed their age to be in the $18-21$ years category. The " $22-25$ years" and "more than 26 years" categories included $16(4.0 \%)$ and seven $(1.7 \%)$ 
respondents, respectively. One $(0.2 \%)$ respondent failed to provide their age (see Table 2).

Table 2

Age of Respondents

\begin{tabular}{lcc}
\hline & $\mathrm{N}$ & $\%$ \\
\hline Less than 18 years & 33 & 8.2 \\
$18-21$ years & 346 & 85.9 \\
$22-25$ years & 16 & 4.0 \\
More than 26 years & 7 & 1.7 \\
No Response & 1 & .2 \\
\hline
\end{tabular}

Ethnicity of Respondents

Respondents were asked to identify their ethnic group. Three hundred sixty-four (90.3\%) respondents listed their ethnicity as "White." The category "Hispanic" was listed by $12(3.0 \%)$ respondents as their ethnicity. Nine $(2.2 \%)$ of the respondents listed their ethnicity as "Black" and six (1.5\%) respondents selected more than one ethnicity, and were classified as "Multi-Ethnic." The category "Asian or Pacific Islander" was listed by five (1.2\%) respondents as their ethnicity. The "Other" category (see Appendix E) included four $(1.0 \%)$ respondents. Two (0.5\%) respondents identified their ethnicity as "American Indian or Alaskan Native" and one (0.2\%) respondent failed to provide their ethnicity (see Table 3). 
Table 3

Ethnicity of Respondents

\begin{tabular}{lcc}
\hline & $\mathrm{N}$ & $\%$ \\
\hline White & 364 & 90.3 \\
Hispanic & 12 & 3.0 \\
Black & 9 & 2.2 \\
Multi-Ethnic & 6 & 1.5 \\
Asian or Pacific Islander & 5 & 1.2 \\
Other & 4 & 1.0 \\
American Indian or Alaskan Native & 2 & .5 \\
No Response & 1 & .2 \\
\hline
\end{tabular}

Home State of Respondents

All respondents in the study were asked to identify their home state. One hundred fifty-two (37.7\%) respondents identified their home state as West Virginia. Seventy-one $(17.6 \%)$ respondents identified their home state as Pennsylvania. New Jersey was reported as the home state for 34 individuals $(8.4 \%)$. Thirty-two $(7.9 \%)$ of the respondents listed their home state as Maryland. Twenty-two (5.5\%) respondents identified their home state as Virginia. Fourteen (3.5\%) respondents identified New York as their home state. Ten $(2.5 \%)$ respondents identified their home state as Ohio. Florida was reported as the home state for four $(1.0 \%)$ respondents. Three $(0.7 \%)$ respondents identified Connecticut and three $(0.7 \%)$ respondents identified Illinois as their home state. There were two $(0.5 \%)$ respondents each for the states of Colorado, Delaware, Georgia, North Carolina, and Rhode Island. There was one $(0.2 \%)$ respondent each for 
the states of Indiana, Kentucky, Maine, Massachusetts, Missouri, Tennessee, and Wisconsin. One (0.2\%) respondent identified their home state as one of the United States' other territories. One $(0.2 \%)$ respondent identified their home state as being multiple states and $39(9.7 \%)$ respondents failed to provide their home state (see Table 4). Table 4

Home State of Respondents

\begin{tabular}{lcc}
\hline & $\mathrm{N}$ & $\%$ \\
\hline WV-West Virginia & 152 & 37.7 \\
PA-Pennsylvania & 71 & 17.6 \\
NJ-New Jersey & 34 & 8.4 \\
MD-Maryland & 32 & 7.9 \\
VA-Virginia & 22 & 5.5 \\
NY-New York & 14 & 3.5 \\
OH-Ohio & 10 & 2.5 \\
FL-Florida & 4 & 1.0 \\
CT-Connecticut & 3 & .7 \\
IL-Illinois & 3 & .7 \\
CO-Colorado & 2 & .5 \\
DE-Delaware & 2 & .5 \\
GA-Georgia & 2 & .5 \\
NC-North Carolina & 2 & .5 \\
RI-Rhode Island & 2 & .5 \\
IN-Indiana & 1 & .2 \\
KY-Kentucky & & .5 \\
\hline
\end{tabular}


Table 4 (Continued)

Home State of Respondents

\begin{tabular}{lcc}
\hline & $\mathrm{N}$ & $\%$ \\
\hline ME-Maine & 1 & .2 \\
MA-Massachusetts & 1 & .2 \\
MO-Missouri & 1 & .2 \\
TN-Tennessee & 1 & .2 \\
WI-Wisconsin & 1 & .2 \\
Other Territory & 1 & .2 \\
Multiple States & 1 & .2 \\
No Response & 39 & 9.7 \\
\hline
\end{tabular}

Home Country of Respondents

All respondents in the study were asked to identify their home country. Three hundred seventy-one (92.1\%) respondents identified the United States of America as their home country. A United States Territory, the United States of America and Asia, Asia, and Central America were each identified by one ( $0.2 \%)$ respondent as their home country. Two $(0.5 \%)$ respondents each identified their home country as Africa and Europe. Twenty-four (6.0\%) respondents failed to identify their home country (see Table $5)$. 
Table 5

Home Country of Respondents

\begin{tabular}{lcc}
\hline & $\mathrm{N}$ & $\%$ \\
\hline United States of America & 371 & 92.1 \\
Africa & 2 & .5 \\
Europe & 2 & .5 \\
United States Territory & 1 & .2 \\
United States of America-Asia & 1 & .2 \\
Asia & 1 & .2 \\
Central America & 1 & .2 \\
No Response & 24 & 6.0 \\
\hline
\end{tabular}

\section{Traditional College Student}

All respondents in the study were asked to identify whether they were a traditional or non-traditional student. Three hundred eighty-two $(94.8 \%)$ respondents were traditional college students while $19(4.7 \%)$ respondents were not traditional college students. Two $(0.5 \%)$ respondents failed to list whether or not they were a traditional college student (see Table 6).

Table 6

Traditional College Student

\begin{tabular}{lcc}
\hline & $\mathrm{N}$ & $\%$ \\
\hline Yes & 382 & 94.8 \\
No & 19 & 4.7 \\
No Response & 2 & .5 \\
\hline
\end{tabular}




\section{College Rank of Respondents}

All respondents in the study were asked to identify their college rank using one of seven categories. One $(0.2 \%)$ respondent failed to list their college rank. Two hundred ninety-eight (73.9\%) respondents listed their college rank as "First Semester Freshman." Sixty-four (15.9\%) respondents listed "Freshman" as their college rank. Twenty-three (5.7\%) respondents listed their college rank as "Sophomore." Eight (2.0\%) respondents each listed their college rank as "Junior" and eight (2.0\%) respondents list their rank as "Senior." One (0.2\%) respondent listed their college rank as "Other," noting that they were a transfer student (see Table 7).

Table 7

College Rank of Respondents

\begin{tabular}{lcc}
\hline & $\mathrm{N}$ & $\%$ \\
\hline First Semester Freshman & 298 & 73.9 \\
Freshman & 64 & 15.9 \\
Sophomore & 23 & 5.7 \\
Junior & 8 & 2.0 \\
Senior & 8 & 2.0 \\
Other & 1 & .2 \\
Graduate Student & 0 & 0.0 \\
No Response & 1 & .2 \\
\hline
\end{tabular}

\section{College Major of Respondents}

All respondents in the study were asked to identify their college major. A complete listing is provided in Appendix F. All majors were then classified within their 
respective colleges within West Virginia University. One hundred fourteen $(28.3 \%)$ respondents identified majors within the Davis College of Agriculture, Forestry, \& Consumer Sciences. Ninety-two (22.8\%) respondents identified majors within the Eberly College of Arts and Sciences. Fifty-nine (14.6\%) respondents identified majors within the College of Business and Economics. Thirty (7.4\%) respondents identified majors within the College of Human Resources and Education. Twenty-one (5.2\%) respondents identified majors within the College of Creative Arts and $21(5.2 \%)$ identified majors in the College of Physical Education. Sixteen (4.0\%) respondents identified their major as undeclared. Ten (2.5\%) respondents identified majors within the Perley Isaac Reed School of Journalism. Nine (2.2\%) respondents identified majors within the School of Medicine. Eight (2.0\%) respondents identified majors within the School of Nursing. Seven (1.7\%) respondents identified majors within the School of Pharmacy. Five (1.2\%) respondents identified majors within the School of Applied Social Sciences. Four (1.0\%) respondents identified majors within the College of Engineering and Mineral Resources. Five $(1.2 \%)$ respondents did not identify their college major. The responses of two $(0.5 \%)$ respondents were illegible (see Table 8$)$. 
Table 8

College Major of Respondents

\begin{tabular}{lcc}
\hline & N & $\%$ \\
\hline $\begin{array}{l}\text { Davis College of Agriculture, Forestry, \& } \\
\text { Consumer Sciences }\end{array}$ & 114 & 28.3 \\
Eberly College of Arts \& Sciences & 92 & 22.8 \\
College of Business \& Economics & 59 & 14.6 \\
College of Human Resources \& Education & 30 & 7.4 \\
College of Creative Arts & 21 & 5.2 \\
School of Physical Education & 21 & 5.2 \\
Undeclared & 16 & 4.0 \\
Perley Isaac Reed School of Journalism & 10 & 2.5 \\
School of Medicine & 9 & 2.2 \\
School of Nursing & 8 & 2.0 \\
School of Pharmacy & 7 & 1.7 \\
School of Applied Social Sciences & 5 & 1.2 \\
College of Engineering \& Mineral Resources & 4 & .5 \\
No Response & 5 & 1.0 \\
Illegible & 5 & \\
\hline
\end{tabular}

\section{Classification of Home Geographical Location of Respondents}

All respondents in the study were asked to identify the geographic location of their homes using four categories. "In a suburb" was selected as the home geographical location of $156(38.7 \%)$ respondents. One hundred twenty-four (30.8\%) respondents identified their home geographical location as "in a rural area, not on a farm." Sixty-six 
(16.4\%) respondents identified "in a city" as their home geographical location. "On a farm or ranch" was identified by $41(10.2 \%)$ respondents as their home geographical location. Thirteen (3.2\%) respondents identified multiple locations as home geographical locations. Three $(0.7 \%)$ respondents had no response (see Table 9).

Table 9

Classification of Home Geographical Location of Respondents

\begin{tabular}{lcc}
\hline & $\mathrm{N}$ & $\%$ \\
\hline In a suburb & 156 & 38.7 \\
In a rural area, not on a farm & 124 & 30.8 \\
In a city & 66 & 16.4 \\
On a farm or ranch & 41 & 10.2 \\
Multiple locations & 13 & 3.2 \\
No response & 3 & .7 \\
\hline
\end{tabular}

\section{Agriculture-Related Work of Respondents}

All respondents in the study were asked to identify if they had ever worked on a farm, ranch, or in an agricultural business, and if so, to identify the type of farm, ranch, or agricultural business. A complete listing of the type of farm, ranch, or agricultural business can be found in Appendix G. In addition, all respondents were asked to identify if they had relatives who live or work on a farm or ranch or who work in an agricultural business. One hundred fifteen (28.5\%) respondents had worked on a farm or ranch, 287 (71.2\%) respondents had not worked on a farm or ranch, and one $(0.2 \%)$ respondent did not make a response. Forty-six (11.4\%) respondents had worked in agribusiness, 356 $(88.3 \%)$ respondents had not worked in agribusiness, and one $(0.2 \%)$ respondent did not 
respond. Two hundred one (49.9\%) respondents had relatives that live or work on a farm, $200(49.6 \%)$ respondents had relatives that do not live or work on a farm, and two $(0.5 \%)$ respondents did not respond. One hundred thirty-three (33.0\%) respondents had relatives that work in agribusiness, 267 (66.3\%) respondents had relatives that do not work in agribusiness, and three (0.7\%) respondents did not respond (see Table 10).

Table 10

Agriculture-Related Work of Respondents

\begin{tabular}{lrrrrrr}
\hline & \multicolumn{2}{c}{ Yes } & \multicolumn{2}{c}{ No } & \multicolumn{2}{c}{ No Response } \\
\cline { 2 - 7 } & $\mathrm{N}$ & $\%$ & $\mathrm{~N}$ & $\mathrm{~N}$ & $\mathrm{~N}$ & $\%$ \\
\hline Work on farm-ranch & 115 & 28.5 & 287 & 71.2 & 1 & .2 \\
Work in agribusiness & 46 & 11.4 & 356 & 88.3 & 1 & .2 \\
Relatives live-work on farm & 201 & 49.9 & 200 & 49.6 & 2 & .5 \\
Relatives work in agribusiness & 133 & 33.0 & 267 & 66.3 & 3 & .7 \\
\hline
\end{tabular}

Agriculture-Related Organizations Available to Respondents within their Communities

Respondents in the study were asked to identify those agriculture-related organizations that were available to them in their home communities using 11 choices. Two hundred four (50.6\%) respondents identified that "4-H" was available within their community. One hundred thirty-four (33.3\%) respondents identified that "FFA" was an organization available in their home community. One hundred ten $(27.3 \%)$ respondents recognized "National Rifle Association" as an organization active in their community. Fifty-nine (14.6\%) respondents knew about "Farm Bureau." Fifty-six (13.9\%) of the respondents did not select any of the choices listed. Twenty-two (5.5\%) of the respondents were aware of "breed associations." Nineteen (4.7\%) of the respondents 
knew about "Grange." Eighteen (4.5\%) respondents identified their awareness of the "National Beef Council" within their home community. Sixteen (4.0\%) of the respondents knew that their community had an "ag cooperative." Four (1.0\%) of the respondents selected "Other" (see Appendix H). One hundred forty-five (36.0\%) of the respondents were unsure about any agriculture-related organizations in their home community and selected "Don't Know" (see Table 11).

Table 11

Agriculture-Related Organizations Available to Respondents within their Communities

\begin{tabular}{lcccc}
\hline & \multicolumn{2}{c}{ Yes } & \multicolumn{2}{c}{ No } \\
\cline { 2 - 5 } & $\mathrm{N}$ & $\%$ & 199 & $\%$ \\
\hline $4-\mathrm{H}$ & 204 & 50.6 & 269 & 69.4 \\
FFA & 134 & 33.3 & 293 & 72.7 \\
National Rifle Association & 110 & 27.3 & 344 & 85.4 \\
Farm Bureau & 59 & 14.6 & 347 & 86.1 \\
None & 56 & 13.9 & 381 & 94.5 \\
Breed Associations & 22 & 5.5 & 384 & 95.3 \\
Grange & 19 & 4.7 & 385 & 95.5 \\
National Beef Council & 18 & 4.5 & 387 & 96.0 \\
Ag Cooperative & 16 & 4.0 & 399 & 99.0 \\
Other & 4 & 1.0 & 258 & 64.0 \\
Don't Know & 145 & 36.0 & & \\
\hline & & & & \\
\hline
\end{tabular}




\section{High School Agriculture Classes Taken by Respondents}

All respondents in the study were asked to identify whether or not they participated in agriculture classes while in high school. Forty-eight (11.9\%) respondents had participated in high school agriculture classes while $352(87.3 \%)$ respondents did not take high school agriculture classes. Three $(0.7 \%)$ respondents had no response (see Table 12).

Table 12

High School Agriculture Classes Taken by Respondents

\begin{tabular}{lcc}
\hline & $\mathrm{N}$ & $\%$ \\
\hline Yes & 48 & 11.9 \\
No & 352 & 87.3 \\
No Response & 3 & .7 \\
\hline
\end{tabular}

High School Offered Agriculture Education Courses

All respondents in the study were asked to identify whether or not their high school offered agriculture education courses. If the students identified that they had taken agriculture courses while in high school they were instructed not to respond to this question, as it is inferred that to take an agriculture class in high school, the high school must offer the courses. One hundred twenty-four (30.8\%) respondents went to a high school that offered agriculture education courses. Two hundred twenty-seven $(56.3 \%)$ respondents attended a high school that did not offer agriculture education courses. Thirty-four (8.4\%) respondents intentionally left the response blank and $18(4.5 \%)$ respondents did not respond (see Table 13). 
Table 13

High School Offered Agriculture Education Courses

\begin{tabular}{lcc}
\hline & $\mathrm{N}$ & $\%$ \\
\hline Yes & 124 & 30.8 \\
No & 227 & 56.3 \\
Intentionally Left Blank & 34 & 8.4 \\
No Response & 18 & 4.5 \\
\hline
\end{tabular}

Member of FFA, 4-H, and Other Agricultural Organization

All respondents in the study were asked to identify whether or not they belonged to FFA, 4-H, or any other agricultural organization. Twenty-nine (7.2\%) respondents were involved in FFA, $364(90.3 \%)$ respondents were not involved in FFA, and 10 $(2.5 \%)$ respondents did not respond to their FFA involvement. In reference to membership in a 4-H program, 60 (14.9\%) respondents were involved, $342(84.9 \%)$ respondents did not participate, and one $(0.2 \%)$ respondent did not respond. Seventeen (4.2\%) respondents were members of other agricultural organizations (see Appendix I), $382(94.8 \%)$ of the respondents were not members of other agricultural organizations, and four (1.0\%) respondents did not respond (see Table 14). 
Table 14

Member of FFA, 4-H, and Other Agriculture Organization

\begin{tabular}{lrrrrrrr}
\hline & \multicolumn{2}{c}{ Yes } & \multicolumn{2}{c}{ No } & \multicolumn{2}{c}{ No Response } \\
\cline { 2 - 8 } & $\mathrm{N}$ & $\%$ & $\mathrm{~N}$ & $\%$ & $\mathrm{~N}$ & $\%$ \\
\hline FFA member & 29 & 7.2 & 364 & 90.3 & 10 & 2.5 \\
4-H member & 60 & 14.9 & 342 & 84.9 & 1 & .2 \\
Member other agricultural organization & 17 & 4.2 & 382 & 94.8 & 4 & 1.0 \\
\hline
\end{tabular}

Involved in Agricultural Organization at West Virginia University

All respondents in the study were asked to identify those organizations, if any, in

which they were involved in at West Virginia University. Twenty-six (6.5\%)

respondents were involved in agricultural organizations at West Virginia University (see

Appendix J), 373 (92.6\%) of the respondents were not involved, and four (1.0\%)

respondents did not respond (see Table 15).

Table 15

Involved in Agricultural Organization at West Virginia University

\begin{tabular}{lcc}
\hline & $\mathrm{N}$ & $\%$ \\
\hline Yes & 26 & 6.5 \\
No & 373 & 92.6 \\
No Response & 4 & 1.0 \\
\hline
\end{tabular}

Definition of a Land Grant College by Respondents

All respondents in the study were asked to identify the definition which characterized a Land Grant University's mission of providing instruction primarily using 
one of four options. The correct statement "agriculture, military tactics, the mechanic arts, and cooperative extension as well as classical studies" was selected by $133(33.0 \%)$ respondents as that which defined a land grant college's mission. One hundred seventeen $(29.0 \%)$ of the respondents defined a land grant college's mission as "research and development of sustainable and environmentally-friendly bio-based energy alternatives." "Scientific research, education, training, and extension projects geared toward the conservation and practical use of U.S. coasts, the Great Lakes and other marine areas" was identified by $81(20.1 \%)$ respondents as that which defined a land grant college. Thirty-two (7.9\%) respondents defined a land grant college as instructing about "urban affairs and public policy." Forty (9.9\%) respondents did not respond (see Table 16). Table 16

Definition of a Land Grant College by Respondents

\begin{tabular}{lcc}
\hline & $\mathrm{N}$ & $\%$ \\
\hline $\begin{array}{l}\text { Agriculture, military tactics, the mechanic arts, and } \\
\text { cooperative extension as well as classical studies }\end{array}$ & 133 & 33.0 \\
$\begin{array}{l}\text { Research and development of sustainable and } \\
\text { environmentally-friendly bio-based energy alternatives }\end{array}$ & 117 & 29.0 \\
$\begin{array}{l}\text { Scientific research, education, training, and extension } \\
\text { projects geared toward the conservation and practical use } \\
\text { of U.S. coasts, the Great Lakes and other marine areas }\end{array}$ & 81 & 20.1 \\
$\begin{array}{l}\text { urban affairs and public policy } \\
\text { No Response }\end{array}$ & 32 & 7.9 \\
\hline
\end{tabular}

Knowledge of West Virginia University’s Association to Agriculture by Respondents All respondents in the study were asked to identify whether or not they were aware that West Virginia University was a Land Grant College, operates several farms, 
and is not the only Land Grant College in West Virginia. If their response was "Yes," they were instructed to specify how they were made aware of these facts. One hundred thirty-nine (34.5\%) respondents knew that WVU was a land grant college (see Appendix K) while $258(64.0 \%)$ respondents identified they did not know and six $(1.5 \%)$ respondents did not respond. One hundred ninety-three (47.9\%) were aware that WVU owns and operates several farms (see Appendix L), 203 (50.4\%) respondents indicated not knowing, and seven (1.7\%) respondents did not respond. Thirty-eight (9.4\%) respondents knew that WVU is not the only land grant college in West Virginia (see Appendix M), 357 (88.6\%) did not know, and eight (2.0\%) respondents failed to respond (see Table 17).

Table 17

Knowledge of West Virginia University's Association to Agriculture by Respondents

\begin{tabular}{lrrrrrrrr}
\hline & \multicolumn{2}{c}{ Yes } & & No & \multicolumn{2}{r}{ No Response } \\
\cline { 2 - 8 } & N & $\%$ & $\mathrm{~N}$ & $\%$ & $\mathrm{~N}$ & $\%$ \\
\hline WVU is a Land Grant College & 139 & 34.5 & 258 & 64.0 & 6 & 1.5 \\
WVU operates several farms & 193 & 47.9 & 203 & 50.4 & 7 & 1.7 \\
WVU is not the only Land Grant College in WV & 38 & 9.4 & 357 & 88.6 & 8 & 2.0 \\
\hline
\end{tabular}

\section{Analysis of Agricultural Literacy Statements}

Responses from all 403 student respondents were analyzed as one group.

Additional analysis was performed after the main group was divided into sub-groups.

The two additional sub-groups were identified using demographic data indicated by respondents on the instrument. Individuals who indicated that they "grew up on a farm or ranch," had "ever worked on a farm or ranch," and/or had "ever worked in an agricultural 
business" were categorized as agricultural background respondents while all other respondents were grouped as non-agricultural background respondents. Individuals who indicated they were enrolled in a major within the Davis College of Agriculture, Forestry, and Consumer Sciences at WVU were categorized as Davis College respondents, while all other respondents who indicated their major as being in another college of WVU were grouped as Non-Davis College respondents. The responses indicated on the instrument for the agricultural knowledge and agricultural perceptions statements were analyzed using three groups: all Respondents, Davis College respondents versus Non-Davis College respondents, and agricultural background respondents versus non-agricultural background respondents.

\section{Responses to Agricultural Knowledge Statements}

Respondents in the study were instructed to select two answers for each of the thirty-five agricultural knowledge statements. If they believed the statement to be true, they were to circle "T," or if they believed the statement to be false, they were to circle "F." Based on their level of confidence in their answer, respondents were also instructed to circle "S" if they were sure their response was correct or " $U$ " if they were unsure of their response. The questions were grouped into four categories: General Agricultural Knowledge, Agricultural Career Literacy, Agricultural Policy Literacy, and Environmental and Natural Resources Agricultural Literacy.

\section{General Agricultural Knowledge}

Within the General Agricultural Knowledge group, there were 13 statements. The first statement was "Animal health and nutrition are important to farmers," to which three hundred sixty-six respondents $(90.8 \%)$ indicated their response as true. Thirty 
respondents $(7.4 \%)$ selected false while seven respondents $(1.7 \%)$ did not respond. Seventy-six respondents (18.9\%) did not indicate their level of confidence in their response, while 257 respondents $(63.8 \%)$ were sure of their answer and 70 respondents $(17.4 \%)$ were unsure of their answer (see Table 18).

Two hundred ninety-nine respondents $(74.2 \%)$ indicated the statement "Processing increases the cost of food production" was true while 18 individuals (4.5\%) failed to respond to the statement. Eighty-six individuals $(21.3 \%)$ felt the statement was false. One hundred seventy individuals $(42.2 \%)$ were sure of their answer and 166 respondents $(41.2 \%)$ indicated they were unsure of their response. Sixty-seven individuals (16.6\%) did not rate their confidence in their answer (see Table 18).

"Plant products are the main source of human food," received 240 respondents (59.6\%) who indicated the statement was true while 13 individuals (3.2\%) did not respond to the statement. One hundred fifty individuals $(37.2 \%)$ identified the statement as false. One hundred forty-two individuals (35.2\%) were certain of their answer while 191 respondents (47.7\%) indicated they were uncertain of their response. Seventy individuals (17.4\%) failed to rate their confidence in their answer (see Table 18).

Respondents were asked to evaluate the statement: "Animals can be a valuable source of medical products." Two hundred seventy-eight respondents (69.0\%) indicated the statement was true. One hundred five respondents $(26.1 \%)$ selected false while 20 respondents $(5.0 \%)$ did not respond. Sixty-seven respondents $(16.6 \%)$ did not indicate their level of confidence in their response, while 140 respondents $(34.7 \%)$ were sure of their answer and 196 respondents (48.6\%) were unsure of their answer (see Table 18). 
"Homogenization kills bacteria in milk with heat" was evaluated by the respondents. Two hundred twenty-two respondents $(55.1 \%)$ indicated the statement was true while 34 individuals $(8.4 \%)$ failed to respond to the statement. One hundred fortyseven individuals $(36.5 \%)$ felt the statement was false. One hundred fifty-three individuals (38.0\%) were sure of their answer and 149 respondents $(48.1 \%)$ indicated they were unsure of their response. Fifty-six individuals (13.9\%) did not rate their confidence in their answer (see Table 18).

Three hundred sixty-four respondents $(90.3 \%)$ indicated the statement "thousands of people in the world die of starvation each year," was true while nine individuals $(2.2 \%)$ did not respond to the statement. Thirty individuals $(7.4 \%)$ identified the statement as false. Two hundred fifty-five individuals $(63.3 \%)$ were certain of their answer while 70 respondents $(17.4 \%)$ indicated they were uncertain of their response. Seventy-eight individuals (19.4\%) failed to rate their confidence in their answer (see Table 18).

Two hundred eighty-three respondents $(70.2 \%)$ indicated the statement "Animals eat foodstuffs that cannot be digested by humans" was true. Ninety-nine respondents (24.6\%) selected false while 21 respondents (5.2\%) did not respond. Sixty-four respondents $(15.9 \%)$ did not indicate their level of confidence in their response, while 168 respondents $(41.7 \%)$ were sure of their answer and 171 respondents $(42.2 \%)$ were unsure of their answer (see Table 18).

"New products have been developed using surplus grains" was evaluated by the respondents. Three hundred eleven respondents $(77.2 \%)$ indicated the statement was true while 26 individuals $(6.5 \%)$ failed to respond to the statement. Sixty-six individuals 
(16.4\%) felt the statement was false. One hundred ten individuals $(27.3 \%)$ were sure of their answer and 231 respondents $(57.3 \%)$ indicated they were unsure of their response. Sixty-two individuals (15.4\%) did not rate their confidence in their answer (see Table 18).

One hundred eighty-one respondents (44.9\%) indicated the statement "Grain exports are usually transported between continents by airplane" was true while 34 individuals (8.4\%) did not respond to the statement. One hundred eighty-one individuals (46.7\%) identified the statement as false. Ninety-nine individuals (24.6\%) were certain of their answer while 252 respondents (62.5\%) indicated they were uncertain of their response. Fifty-two individuals (12.9\%) failed to rate their confidence in their answer (see Table 18).

Two hundred forty-eight respondents (61.5\%) indicated "Biotechnology has increased animal production in the US" was a true statement. One hundred twenty-eight respondents (31.8\%) selected false while 27 respondents (6.7\%) did not respond. Sixtytwo respondents (15.4\%) did not indicate their level of confidence in their response, while 153 respondents $(33.5 \%)$ were sure of their answer and 206 respondents $(51.1 \%)$ were unsure of their answer (see Table 18).

Two hundred seventy-five respondents (68.2\%) indicated the statement "Pasteurization kills bacteria in milk with heat" was true while 25 individuals (6.2\%) failed to respond to the statement. One hundred three individuals (25.6\%) felt the statement was false. One hundred seventy-eight individuals (44.2\%) were sure of their answer and 164 respondents (40.7\%) indicated they were unsure of their response. Sixtyone individuals (15.1\%) did not rate their confidence in their answer (see Table 18). 
Forty-five respondents (11.2\%) indicated the statement "Hamburger is made from the meat of pigs" was true while 154 individuals (3.7\%) did not respond to the statement. Three hundred forty-three individuals (85.1\%) identified the statement as false. Two hundred fifty-three individuals (62.8\%) were certain of their answer while 78 respondents (19.4\%) indicated they were uncertain of their response. Seventy-two individuals (17.9\%) failed to rate their confidence in their answer (see Table 18).

Three hundred sixteen respondents (78.4\%) indicated the statement "Transportation and storage affects the supply of agricultural products" was true. Sixtythree respondents (15.6\%) selected false while 24 respondents $(6.0 \%)$ did not respond. Seventy respondents (17.4\%) did not indicate their level of confidence in their response, while 180 respondents (44.7\%) were sure of their answer and 153 respondents (38.0\%) were unsure of their answer (see Table 18). 
Table 18

Responses to Agricultural Knowledge Statements - General Agricultural Knowledge

\begin{tabular}{|c|c|c|c|c|c|c|c|c|c|c|c|c|}
\hline & \multicolumn{2}{|c|}{ No Response } & \multicolumn{2}{|c|}{ True } & \multicolumn{2}{|c|}{ False } & \multicolumn{2}{|c|}{ No Response } & \multicolumn{2}{|c|}{ Sure } & \multicolumn{2}{|c|}{ Unsure } \\
\hline & $\mathrm{N}$ & $\%$ & $\mathrm{~N}$ & $\%$ & $\mathrm{~N}$ & $\%$ & $\mathrm{~N}$ & $\%$ & $\mathrm{~N}$ & $\%$ & $\mathrm{~N}$ & $\%$ \\
\hline $\begin{array}{l}\text { Animal health and nutrition are } \\
\text { important to farmers }\end{array}$ & 7 & 1.7 & 366 & 90.8 & 30 & 7.4 & 76 & 18.9 & 257 & 63.8 & 70 & 17.4 \\
\hline $\begin{array}{l}\text { Processing increases the cost of } \\
\text { food products }\end{array}$ & 18 & 4.5 & 299 & 74.2 & 86 & 21.3 & 67 & 16.6 & 170 & 42.2 & 166 & 41.2 \\
\hline $\begin{array}{l}\text { Plant products are the main source } \\
\text { of human foods }\end{array}$ & 13 & 3.2 & 240 & 59.6 & 150 & 37.2 & 70 & 17.4 & 142 & 35.2 & 191 & 47.4 \\
\hline $\begin{array}{l}\text { Animals can be a valuable source of } \\
\text { medical products }\end{array}$ & 20 & 5.0 & 278 & 69.0 & 105 & 26.1 & 67 & 16.6 & 140 & 34.7 & 196 & 48.6 \\
\hline $\begin{array}{l}\text { Homogenization kills bacteria in } \\
\text { milk with heat }\end{array}$ & 34 & 8.4 & 222 & 55.1 & 147 & 36.5 & 56 & 13.9 & 153 & 38.0 & 194 & 48.1 \\
\hline $\begin{array}{l}\text { Thousands of people in the world } \\
\text { die of starvation each year }\end{array}$ & 9 & 2.2 & 364 & 90.3 & 30 & 7.4 & 78 & 19.4 & 255 & 63.3 & 70 & 17.4 \\
\hline $\begin{array}{l}\text { Animals eat foodstuffs that cannot } \\
\text { be digested by humans }\end{array}$ & 21 & 5.2 & 283 & 70.2 & 99 & 24.6 & 64 & 15.9 & 168 & 41.7 & 171 & 42.4 \\
\hline $\begin{array}{l}\text { New products have been developed } \\
\text { using surplus grains }\end{array}$ & 26 & 6.5 & 311 & 77.2 & 66 & 16.4 & 62 & 15.4 & 110 & 27.3 & 231 & 57.3 \\
\hline
\end{tabular}


Table 18 (Continued)

Responses to Agricultural Knowledge Statements - General Agricultural Knowledge

\begin{tabular}{|c|c|c|c|c|c|c|c|c|c|c|c|c|}
\hline & \multicolumn{2}{|c|}{ No Response } & \multicolumn{2}{|c|}{ True } & \multicolumn{2}{|c|}{ False } & \multicolumn{2}{|c|}{ No Response } & \multicolumn{2}{|c|}{ Sure } & \multicolumn{2}{|c|}{ Unsure } \\
\hline & $\mathrm{N}$ & $\%$ & $\mathrm{~N}$ & $\%$ & $\mathrm{~N}$ & $\%$ & $\mathrm{~N}$ & $\%$ & $\mathrm{~N}$ & $\%$ & $\mathrm{~N}$ & $\%$ \\
\hline $\begin{array}{l}\text { Grain exports are usually } \\
\text { transported between continents by } \\
\text { airplane }\end{array}$ & 34 & 8.4 & 181 & 44.9 & 188 & 46.7 & 52 & 12.9 & 99 & 24.6 & 252 & 62.5 \\
\hline $\begin{array}{l}\text { Biotechnology has increased animal } \\
\text { production in the US }\end{array}$ & 27 & 6.7 & 248 & 61.5 & 128 & 31.8 & 62 & 15.4 & 135 & 33.5 & 206 & 51.1 \\
\hline $\begin{array}{l}\text { Pasteurization kills bacteria in milk } \\
\text { with heat }\end{array}$ & 25 & 6.2 & 275 & 68.2 & 103 & 25.6 & 61 & 15.1 & 178 & 44.2 & 164 & 40.7 \\
\hline $\begin{array}{l}\text { Hamburger is made from the meat } \\
\text { of pigs }\end{array}$ & 15 & 3.7 & 45 & 11.2 & 343 & 85.1 & 72 & 17.9 & 253 & 62.8 & 78 & 19.4 \\
\hline $\begin{array}{l}\text { Transportation and storage affects } \\
\text { the supply of agricultural products }\end{array}$ & 24 & 6.0 & 316 & 78.4 & 63 & 15.6 & 70 & 17.4 & 180 & 44.7 & 153 & 38.0 \\
\hline
\end{tabular}




\section{General Agricultural Knowledge Comparisons by Groups}

The 403 student respondents were divided into two groups: Davis College Respondents $(n=114)$ and Non-Davis College Respondents $(n=284)$ for the first analysis. The 403 student respondents were divided into two different groups: agricultural background respondents $(n=129)$ and non-agricultural background respondents $(n=274)$ for the second analysis. A composite score was calculated by adding the responses to the 13 statements in this category $(1=\operatorname{correct}$ answer $0=$ incorrect answer). The $t$-test statistical procedures were used to determine if statistical differences existed in the means of each of the comparison groups for General Agricultural Knowledge (GAK). The following hypotheses were tested:

$\mathrm{H}_{0}=M_{\text {Davis College GAK }}=M_{\text {Non-Davis College GAK }}$

$\mathrm{H}_{1}=M_{\text {Davis College GAK }} \neq M_{\text {Non-Davis College GAK }}$

and

$\mathrm{H}_{0}=M_{\text {Agricultural Background GAK }}=M_{\text {Non-Agricultural Background GAK }}$

$\mathrm{H}_{1}=M_{\text {Agricultural Background GAK }} \neq M_{\text {Non-Agricultural Background GAK }}$

The maximum score possible for the 13 General Agricultural Knowledge statements was 13. A mean score of $9.08(S D=2.25)$ was calculated for all 403 respondents. The mean score of Davis College respondents was $9.90(S D=2.30)$. The mean score of Non-Davis College Respondents was $8.75(S D=2.17)$. The mean overall score of agricultural background respondents was $9.58(S D=2.22)$. The mean overall score of non-agricultural background respondents was $8.84(S D=2.24)$ (see Table 19).

Independent $t$-test statistical analysis procedures were used to compare the means of each of the two groups, Davis College and Non-Davis College respondents, and 
agricultural and non-agricultural background respondents for General Agricultural Knowledge. The statistical analysis results (Davis/Non-Davis College: $t=4.711, \mathrm{df}=$ 396; agricultural/non-agricultural background: $t=3.116, \mathrm{df}=401$ ) were significant at $\alpha$ $\leq 0.05$. Both null hypothesis were rejected and the research hypotheses, $H_{1}=M_{\text {Davis College }}$ GAK $\neq M_{\text {Non-Davis College GAK }}$ and $\mathrm{H}_{1}=M_{\text {Agricultural Background GAK }} \neq M_{\text {Non-Agricultural Background GAK }}$, were accepted. Davis College majors scored higher on the General Agricultural Knowledge statements than their Non-Davis College counterparts. Students with an agricultural background scored higher on the General Agricultural Knowledge statements than students without an agricultural background. The difference between the mean scores for General Agricultural Knowledge of the Davis College/Non-Davis College group exhibited a small effect size $(d=.23)$ and the difference between the mean scores for General Agricultural Knowledge of the Agricultural/Non-Agricultural Background group also exhibited a small effect size $(d=.15)$ (Cohen, 1988).

Table 19

General Agricultural Knowledge Scores

\begin{tabular}{lccccc}
\hline & $N$ & $M^{1}$ & $S D$ & $d f$ & $t$ \\
\hline All Respondents & 403 & 9.08 & & & $4.711^{*}$ \\
\hline $\begin{array}{l}\text { Davis College Respondents } \\
\begin{array}{l}\text { Non-Davis College } \\
\text { Respondents }\end{array}\end{array}$ & 114 & 9.90 & 2.30 & 396 & \\
\hline $\begin{array}{l}\text { Agricultural Background } \\
\text { Respondents }\end{array}$ & 129 & 9.58 & 2.22 & 401 & $3.946^{*}$ \\
$\begin{array}{l}\text { Non-Agricultural Background } \\
\text { Respondents }\end{array}$ & 274 & 8.84 & 2.24 & & \\
\hline
\end{tabular}

$* \alpha \leq 0.05$

${ }^{1}$ Maximum score $=13$ 


\section{Agricultural Career Literacy}

The group, Agricultural Career Literacy, contained five statements for the respondents to evaluate. Seventy-four respondents (18.4\%) indicated the statement "There are more farmers in the US than there were 10 years ago" was true while 14 individuals (3.5\%) failed to respond to the statement. Three hundred fifteen individuals (78.2\%) felt the statement was false. One hundred and sixty-seven individuals (41.4\%) were sure of their answer and 164 respondents $(40.7 \%)$ indicated they were unsure of their response. Seventy-two individuals (17.9\%) did not rate their confidence in their answer (see Table 20).

One hundred and thirty-nine respondents (34.5\%) indicated the statement "Less than 3 percent of the US gross national product is from agriculture" was true while 23 individuals (5.7\%) did not respond to the statement. Two hundred and forty-one individuals (59.8\%) identified the statement as false. One hundred and twenty-two individuals (30.3\%) were certain of their answer while 116 respondents $(53.6 \%)$ indicated they were uncertain of their response. Sixty-five individuals (16.1\%) failed to rate their confidence in their answer (see Table 20).

Two hundred thirty-three respondents (57.8\%) indicated the statement "One of every five jobs in the US is related to agriculture" was true. One hundred forty-two respondents (35.2\%) selected false while 28 respondents (6.9\%) did not respond. Sixtyone respondents (15.1\%) did not indicate their level of confidence in their response, while 105 respondents (26.1\%) were sure of their answer and 237 respondents (58.8\%) were unsure of their answer (see Table 20).

One hundred eighty-nine respondents $(46.9 \%)$ indicated the statement "The average US farm is larger than 500 acres" was true while 31 individuals (7.7\%) failed to 
respond to the statement. One hundred eighty-three individuals (45.4\%) felt the statement was false. One hundred ten individuals (27.3\%) were sure of their answer and 237 respondents (58.8\%) indicated they were unsure of their response. Fifty-six individuals (13.9\%) did not rate their confidence in their answer (see Table 20).

"Profits increase as farmers strive for the maximum crop yields" received 254 respondents $(63.0 \%)$ who indicated the statement was true while 23 individuals (5.7\%) did not respond to the statement. One hundred twenty-six individuals (31.3\%) identified the statement as false. One hundred forty-one individuals (35.0\%) were certain of their answer while 197 respondents (48.9\%) indicated they were uncertain of their response. Sixty-five individuals (16.1\%) failed to rate their confidence in their answer (see Table 20). 
Table 20

Responses to Agricultural Knowledge Statements - Agricultural Career Literacy

\begin{tabular}{|c|c|c|c|c|c|c|c|c|c|c|c|c|}
\hline & \multicolumn{2}{|c|}{ No Response } & \multicolumn{2}{|c|}{ True } & \multicolumn{2}{|c|}{ False } & \multicolumn{2}{|c|}{ No Response } & \multicolumn{2}{|c|}{ Sure } & \multicolumn{2}{|c|}{ Unsure } \\
\hline & $\mathrm{N}$ & $\%$ & $\mathrm{~N}$ & $\%$ & $\mathrm{~N}$ & $\%$ & $\mathrm{~N}$ & $\%$ & $\mathrm{~N}$ & $\%$ & $\mathrm{~N}$ & $\%$ \\
\hline $\begin{array}{l}\text { There are more farmers in the US } \\
\text { than there were } 10 \text { years ago }\end{array}$ & 14 & 3.5 & 74 & 18.4 & 315 & 78.2 & 72 & 17.9 & 167 & 41.4 & 164 & 40.7 \\
\hline $\begin{array}{l}\text { Less than } 3 \text { percent of the US gross } \\
\text { national product is from agriculture }\end{array}$ & 23 & 5.7 & 139 & 34.5 & 241 & 59.8 & 65 & 16.1 & 122 & 30.3 & 216 & 53.6 \\
\hline $\begin{array}{l}\text { One of every five jobs in the US is } \\
\text { related to agriculture }\end{array}$ & 28 & 6.9 & 233 & 57.8 & 142 & 35.2 & 61 & 15.1 & 105 & 26.1 & 237 & 58.8 \\
\hline $\begin{array}{l}\text { The average US farm is larger than } \\
500 \text { acres }\end{array}$ & 31 & 7.7 & 189 & 46.9 & 183 & 45.4 & 56 & 13.9 & 110 & 27.3 & 237 & 58.8 \\
\hline $\begin{array}{l}\text { Profits increase as farmers strive for } \\
\text { the maximum crop yields }\end{array}$ & 23 & 5.7 & 254 & 63.0 & 126 & 31.3 & 65 & 16.1 & 141 & 35.0 & 197 & 48.9 \\
\hline
\end{tabular}




\section{Agricultural Career Literacy Comparisons by Groups}

The 403 student respondents were divided into two groups: Davis College Respondents $(n=114)$ and Non-Davis College Respondents $(n=284)$ for the first analysis. The 403 student respondents were divided into two different groups: agricultural background respondents $(n=129)$ and non-agricultural background respondents $(n=274)$ for the second analysis. A composite score was calculated by adding the responses to the five statements in this category $(1=$ correct answer, $0=$ incorrect answer). The $t$-test statistical procedures were used to determine if statistical differences existed in the means of each of the comparison groups for Agricultural Career Literacy (ACL). The following hypotheses were tested:

$\mathrm{H}_{0}=M_{\text {Davis College ACL }}=M_{\text {Non-Davis College ACL }}$

$\mathrm{H}_{1}=M_{\text {Davis College ACL }} \neq M_{\text {Non-Davis College ACL }}$

and

$\mathrm{H}_{0}=M_{\text {Agricultural Background ACL }}=M_{\text {Non-Agricultural Background ACL }}$

$\mathrm{H}_{1}=M_{\text {Agricultural Background ACL }} \neq M_{\text {Non-Agricultural Background ACL }}$

The maximum score possible for the true and false questions pertaining to the Agricultural Career Literacy statements was five and a mean score of $3.04(S D=1.16)$ was found for all 403 respondents. The mean overall score of Davis College respondents was 3.38 with a standard deviation of 1.21 . The mean overall score of Non-Davis College respondents was 2.91 with a standard deviation of 1.11 . The mean overall score of agricultural background respondents was 3.33 with a standard deviation of 1.12 . The mean overall score of non-agricultural background respondents was 2.91 with a standard deviation of 1.16 (see Table 21). 
Independent $t$-test statistical analysis procedures were used to compare the means of each of Davis College and Non-Davis College respondents and agricultural and nonagricultural background respondents for Agricultural Career Literacy. The statistical analysis results (Davis/Non-Davis College: $t=3.536, \mathrm{df}=193$; Agricultural/NonAgricultural Background: $t=3.501, \mathrm{df}=401)$ were significant at $\alpha \leq 0.05$. Both null hypothesis were rejected and the research hypotheses, $\mathrm{H}_{1}=M_{\text {Davis College ACL }} \neq M_{\text {Non-Davis }}$ College ACL and $\mathrm{H}_{1}=M_{\text {Agricultural Background ACL }} \neq M_{\text {Non-Agricultural Background ACL, were accepted. }}$ Davis College majors scored higher on the Agricultural Career Literacy statements than their Non-Davis College counterparts. Students with an agricultural background scored higher on the Agricultural Career Literacy statements than students without an agricultural background. The difference between the mean scores for Agricultural Career Literacy of the Davis College/Non-Davis College group exhibited a small effect size ( $d=$ .36) and the difference between the mean scores for Agricultural Career Literacy of the agricultural/non-agricultural background group also exhibited a small effect size $(d=.32)$ (Cohen, 1988). 
Table 21

Agricultural Career Literacy Scores

\begin{tabular}{lccccc}
\hline & $N$ & $M^{1}$ & $S D$ & $d f$ & $t$ \\
\hline All Respondents & 403 & 3.04 & 1.16 & & $3.536^{*}$ \\
\hline $\begin{array}{l}\text { Davis College Respondents } \\
\begin{array}{l}\text { Non-Davis College } \\
\text { Respondents }\end{array}\end{array}$ & 114 & 3.38 & 1.21 & 193 & \\
\hline $\begin{array}{l}\text { Agricultural Background } \\
\text { Respondents }\end{array}$ & 129 & 3.33 & 1.12 & 401 & $3.501^{*}$ \\
$\begin{array}{l}\text { Non-Agricultural Background } \\
\text { Respondents }\end{array}$ & 274 & 2.91 & 1.16 & & \\
\hline
\end{tabular}

$* \alpha \leq 0.05$

${ }^{1}$ Maximum score $=5$

Agricultural Policy Literacy

The third portion of Agricultural Knowledge Statements, Agricultural Policy Literacy, had a total of 10 statements to which students were to respond. Three hundred sixty-one respondents (89.6\%) indicated the statement "Food safety is a major concern of the food processing industry" was true while five individuals (12\%) did not respond to the statement. Thirty-seven individuals (9.2\%) identified the statement as false. Two hundred fifty-seven individuals (63.8\%) were certain of their answer while 68 respondents (16.9\%) indicated they were uncertain of their response. Seventy-eight individuals (19.4\%) failed to rate their confidence in their answer (see Table 22).

Three hundred fourteen respondents (77.9\%) indicated "US research has improved farming methods in other countries" was true. Seventy respondents (17.4\%) selected false while 19 respondents (4.7\%) did not respond. Sixty-eighty respondents $(16.9 \%)$ did not indicate their level of confidence in their response, while 148 
respondents (36.7\%) were sure of their answer and 187 respondents $(46.4 \%)$ were unsure of their answer (see Table 22).

Eighty-one respondents (20.1\%) indicated the statement "The US does not sell its feed grains on the world market" was true while 28 individuals $(6.9 \%)$ failed to respond to the statement. Two hundred ninety-four individuals $(73.0 \%)$ felt the statement was false. Ninety-one individuals (22.6\%) were sure of their answer and 251 respondents $(62.3 \%)$ indicated they were unsure of their response. Sixty-one individuals $(15.1 \%)$ did not rate their confidence in their answer (see Table 22).

Forty-seven respondents (11.7\%) indicated the statement "Local laws and regulations have little effect on farmers" was true while 12 individuals (3.0\%) did not respond to the statement. Three hundred forty-four individuals $(85.4 \%)$ identified the statement as false. Two hundred eleven individuals (52.4\%) were certain of their answer while 119 respondents (29.5\%) indicated they were uncertain of their response. Seventythree individuals $(18.1 \%$ ) failed to rate their confidence in their answer (see Table 22).

Two hundred eighty-four respondents (70.5\%) indicated "US agricultural policies influence food prices in other countries" was true. Eighty-seven respondents $(21.6 \%)$ selected false while 32 respondents (7.9\%) did not respond. Sixty-three respondents (15.6\%) did not indicate their level of confidence in their response, while 125 respondents $(31.0 \%)$ were sure of their answer and 215 respondents $(53.3 \%)$ were unsure of their answer (see Table 22).

Three hundred forty-six respondents $(85.9 \%)$ indicated the statement "An efficient food distribution system is essential to the agriculture industry" was true while 12 individuals (3.0\%) failed to respond to the statement. Forty-five individuals 
(11.2\%) felt the statement was false. Two hundred nine individuals (51.9\%) were sure of their answer and 119 respondents (29.5\%) indicated they were unsure of their response. Seventy-five individuals (18.6\%) did not rate their confidence in their answer (see Table 22).

Three hundred fourteen respondents (77.9\%) indicated the statement "Several countries depend on US agricultural exports for food and fiber" was true while 13 individuals (3.2\%) did not respond to the statement. Seventy-six individuals (18.9\%) identified the statement as false. One hundred eighty individuals (44.7\%) were certain of their answer while 151 respondents (37.5\%) indicated they were uncertain of their response. Seventy-two individuals (17.9\%) failed to rate their confidence in their answer (see Table 22).

Two hundred fifty respondents (62.0\%) indicated "Government subsidy payments to farmers are used to stabilize food prices" was true. One hundred twenty-five respondents (31.0\%) selected false while 28 respondents (6.9\%) did not respond. Sixty respondents (14.9\%) did not indicate their level of confidence in their response, while 119 respondents (29.5\%) were sure of their answer and 224respondents (55.6\%) were unsure of their answer (see Table 22).

One hundred forty-one respondents (35.0\%) indicated the statement "Very little of the grain produced in the US is exported" was true while 28 individuals (6.9\%) failed to respond to the statement. Two hundred thirty-four individuals (58.1\%) felt the statement was false. One hundred two individuals $(25.3 \%)$ were sure of their answer and 242 respondents $(60.0 \%)$ indicated they were unsure of their response. Fifty-nine individuals (14.6\%) did not rate their confidence in their answer (see Table 22). 
Table 22

Responses to Agricultural Knowledge Statements - Agricultural Policy Literacy

\begin{tabular}{|c|c|c|c|c|c|c|c|c|c|c|c|c|}
\hline & \multicolumn{2}{|c|}{ No Response } & \multicolumn{2}{|c|}{ True } & \multicolumn{2}{|c|}{ False } & \multicolumn{2}{|c|}{ No Response } & \multicolumn{2}{|c|}{ Sure } & \multicolumn{2}{|c|}{ Unsure } \\
\hline & $\mathrm{N}$ & $\%$ & $\mathrm{~N}$ & $\%$ & $\mathrm{~N}$ & $\%$ & $\mathrm{~N}$ & $\%$ & $\mathrm{~N}$ & $\%$ & $\mathrm{~N}$ & $\%$ \\
\hline $\begin{array}{l}\text { Food safety is a major concern of } \\
\text { the food processing industry }\end{array}$ & 5 & 1.2 & 361 & 89.6 & 37 & 9.2 & 78 & 19.4 & 257 & 63.8 & 68 & 16.9 \\
\hline $\begin{array}{l}\text { US research has improved farming } \\
\text { methods in other countries }\end{array}$ & 19 & 4.7 & 314 & 77.9 & 70 & 17.4 & 68 & 16.9 & 148 & 36.7 & 187 & 46.4 \\
\hline $\begin{array}{l}\text { The US does not sell its feed grains } \\
\text { on the world market }\end{array}$ & 28 & 6.9 & 81 & 20.1 & 294 & 73.0 & 61 & 15.1 & 91 & 22.6 & 251 & 62.3 \\
\hline $\begin{array}{l}\text { Local laws and regulations have } \\
\text { little effect on farmers }\end{array}$ & 12 & 3.0 & 47 & 11.7 & 344 & 85.4 & 73 & 18.1 & 211 & 52.4 & 119 & 29.5 \\
\hline $\begin{array}{l}\text { US agricultural policies influence } \\
\text { food prices in other countries }\end{array}$ & 32 & 7.9 & 284 & 70.5 & 87 & 21.6 & 63 & 15.6 & 125 & 31.0 & 215 & 53.3 \\
\hline $\begin{array}{l}\text { An efficient food distribution } \\
\text { system is essential to the agriculture } \\
\text { industry }\end{array}$ & 12 & 3.0 & 346 & 85.9 & 45 & 11.2 & 75 & 18.6 & 209 & 51.9 & 119 & 29.5 \\
\hline $\begin{array}{l}\text { Several countries depend on US } \\
\text { agricultural exports for food and } \\
\text { fiber }\end{array}$ & 13 & 3.2 & 314 & 77.9 & 76 & 18.9 & 72 & 17.9 & 180 & 44.7 & 151 & 37.5 \\
\hline
\end{tabular}


Table 22 (Continued)

Responses to Agricultural Knowledge Statements - Agricultural Policy Literacy

\begin{tabular}{|c|c|c|c|c|c|c|c|c|c|c|c|c|}
\hline & \multicolumn{2}{|c|}{ No Response } & \multicolumn{2}{|c|}{ True } & \multicolumn{2}{|c|}{ False } & \multicolumn{2}{|c|}{ No Response } & \multicolumn{2}{|c|}{ Sure } & \multicolumn{2}{|c|}{ Unsure } \\
\hline & $\mathrm{N}$ & $\%$ & $\mathrm{~N}$ & $\%$ & $\mathrm{~N}$ & $\%$ & $\mathrm{~N}$ & $\%$ & $\mathrm{~N}$ & $\%$ & $\mathrm{~N}$ & $\%$ \\
\hline $\begin{array}{l}\text { Government subsidy payments to } \\
\text { farmers are used to stabilize food } \\
\text { prices }\end{array}$ & 28 & 6.9 & 250 & 62.0 & 125 & 31.0 & 60 & 14.9 & 119 & 29.5 & 224 & 55.6 \\
\hline $\begin{array}{l}\text { Very little of the grain produced in } \\
\text { the US is exported }\end{array}$ & 28 & 6.9 & 141 & 35.0 & 234 & 58.1 & 59 & 14.6 & 102 & 25.3 & 242 & 60.0 \\
\hline $\begin{array}{l}\text { Using grain alcohol for fuel reduces } \\
\text { the US dependence on foreign oil }\end{array}$ & 33 & 8.2 & 255 & 63.3 & 115 & 28.5 & 56 & 13.9 & 182 & 45.2 & 165 & 40.9 \\
\hline
\end{tabular}


Two hundred fifty-five respondents (63.3\%) indicated the statement "Using grain alcohol for fuel reduces the US dependence on foreign oil" was true while 33 individuals $(8.2 \%)$ did not respond to the statement. One hundred fifteen individuals (28.5\%) identified the statement as false. One hundred eighty-two individuals (45.2\%) were certain of their answer while 165 respondents $(40.9 \%)$ indicated they were uncertain of their response. Fifty-six individuals (13.9\%) failed to rate their confidence in their answer (see Table 22).

\section{Agricultural Policy Literacy Comparisons by Groups}

The 403 student respondents were divided into two groups: Davis College Respondents ( $n=114)$ and Non-Davis College Respondents $(n=284)$ for the first analysis. The 403 student respondents were divided into two different groups: agricultural background respondents $(n=129)$ and non-agricultural background respondents $(n=274)$ for a second analysis. A composite score was calculated by adding the responses to the ten statements in this category $(1=$ correct answer, $0=$ incorrect answer). The $t$-test statistical procedures were used to determine if statistical differences existed in the means of each of the comparison groups for Agricultural Policy Literacy (APL). The following sets of hypotheses were tested:

$$
\begin{aligned}
& \mathrm{H}_{0}=M_{\text {Davis College APL }}=M_{\text {Non-Davis College APL }} \\
& \mathrm{H}_{1}=M_{\text {Davis College APL }} \neq M_{\text {Non-Davis College APL }} \\
& \text { and } \\
& \mathrm{H}_{0}=M_{\text {Agricultural Background APL }}=M_{\text {Non-Agricultural Background APL }} \\
& \mathrm{H}_{1}=M_{\text {Agricultural Background APL }} \neq M_{\text {Non-Agricultural Background APL }}
\end{aligned}
$$


The maximum score possible for the true and false questions pertaining to the Agricultural Policy Literacy statements was 10 and a mean score of 7.43 with a standard deviation of 1.97 was found for all 403 respondents. The mean overall score of Davis College Respondents was 8.01 with a standard deviation of 1.85 . The mean overall score of Non-Davis College Respondents was 7.19 with a standard deviation of 1.99 . The mean overall score of Agricultural Background Respondents was 7.85 with a standard deviation of 1.91. The mean overall score of Non-Agricultural Background Respondents was 7.24 with a standard deviation of 1.97 (see Table 23).

Independent $t$-test statistical analysis procedures were used to compare the means of each of the two groups, Davis College and Non-Davis College respondents, and agricultural and non-agricultural background respondents for Agricultural Policy Literacy. The statistical analysis results (Davis/Non-Davis College: $t=3.888, \mathrm{df}=223$; Agricultural/Non-Agricultural Background: $t=2.951, \mathrm{df}=401)$ were significant at $\alpha \leq$ 0.05. Both null hypothesis were rejected and the research hypotheses, $\mathrm{H}_{1}=M_{\text {Davis College }}$ APL $\neq M_{\text {Non-Davis College APL }}$ and $\mathrm{H}_{1}=M_{\text {Agricultural Background APL }} \neq M_{\text {Non-Agricultural Background APL }}$ were accepted. Davis College majors scored higher on the Agricultural Policy Literacy statements than their Non-Davis College counterparts. Students with an agricultural background scored higher on the Agricultural Policy Literacy statements than students without an agricultural background. The difference between the mean scores for Agricultural Policy Literacy of the Davis College/Non-Davis College group exhibited a small effect size $(d=.22)$ and the difference between the mean scores for Agricultural Policy Literacy of the Agricultural/Non-Agricultural Background group exhibited a small effect size $(d=.16)$ (Cohen, 1988). 
Table 23

Agricultural Policy Literacy Scores

\begin{tabular}{|c|c|c|c|c|c|}
\hline & $N$ & $M^{1}$ & $S D$ & $d f$ & $t$ \\
\hline All Respondents & 403 & 7.43 & 1.97 & & \\
\hline Davis College Respondents & 114 & 8.01 & 1.85 & 223 & $3.888^{*}$ \\
\hline $\begin{array}{l}\text { Non-Davis College } \\
\text { Respondents }\end{array}$ & 284 & 7.19 & 1.99 & & \\
\hline $\begin{array}{l}\text { Agricultural Background } \\
\text { Respondents }\end{array}$ & 129 & 7.85 & 1.91 & 401 & $2.951^{*}$ \\
\hline $\begin{array}{l}\text { Non-Agricultural Background } \\
\text { Respondents }\end{array}$ & 274 & 7.24 & 1.97 & & \\
\hline
\end{tabular}

$* \alpha \leq 0.05$

${ }^{1}$ Maximum score $=10$

\section{Environmental and Natural Resources Agricultural Literacy}

In the fourth group of Agricultural Knowledge Statements, Environmental and

Natural Resources Agricultural Literacy, students were instructed to indicate responses to seven statements. The first statement was "Soil erosion does NOT pollute US lakes and rivers." Fifty-nine respondents (14.6\%) indicated their response as true. Three hundred thirty-five respondents (83.1\%) selected false while nine respondents $(2.2 \%)$ did not respond. Seventy-six respondents (18.9\%) did not indicate their level of confidence in their response, while 216 respondents $(53.6 \%)$ were sure of their answer and 111 respondents (27.5\%) were unsure of their answer (see Table 24).

Two hundred eighty-eight respondents (71.5\%) indicated the statement "The use of pesticides has increased the yield of crops" was true while 18 individuals (4.5\%) failed to respond to the statement. Ninety-seven individuals $(24.1 \%)$ felt the statement was false. One hundred forty-eight individuals (36.7\%) were sure of their answer and 188 
respondents (46.7\%) indicated they were unsure of their response. Sixty-seven individuals (16.6\%) did not rate their confidence in their answer (see Table 24).

Two hundred seventy-four respondents $(68.0 \%)$ indicated the statement "Many farmers use tillage practices that conserve the soil" was true while 29 individuals (7.2\%) did not respond to the statement. One hundred individuals (24.8\%) identified the statement as false. One hundred individuals $(24.8 \%)$ were certain of their answer while 244 respondents $(60.5 \%)$ indicated they were uncertain of their response. Fiftynine individuals (14.6\%) failed to rate their confidence in their answer (see Table 24).

Ninety-one respondents (22.6\%) indicated "Farming and wildlife cannot survive in the same geographic area" was true. Two hundred ninety-two respondents (72.5\%) selected false while 20 respondents (5.0\%) did not respond. Sixty-seven respondents (16.6\%) did not indicate their level of confidence in their response, while 170 respondents $(42.2 \%)$ were sure of their answer and 166 respondents $(41.2 \%)$ were unsure of their answer (see Table 24).

Three hundred ten respondents (76.9\%) indicated the statement "Biotechnology has increased the pest resistance of plants" was true while 25 individuals (6.2\%) failed to respond to the statement. Sixty-eight individuals (16.9\%) felt the statement was false. One hundred sixty-one individuals $(40.0 \%)$ were sure of their answer and 181 respondents (44.9\%) indicated they were unsure of their response. Sixty-one individuals (15.1\%) did not rate their confidence in their answer (see Table 24).

Three hundred sixty-one respondents (89.6\%) indicated the statement "Animal wastes are used to increase soil fertility," was true while 13 individuals (3.2\%) did not respond to the statement. Twenty-nine individuals (7.2\%) identified the statement 
as false. Two hundred thirty-two individuals (57.6\%) were certain of their answer while 100 respondents $(24.8 \%)$ indicated they were uncertain of their response. Seventyone individuals (17.6\%) failed to rate their confidence in their answer (see Table 24).

Three hundred sixty-six respondents (90.8\%) indicated the statement "Water, soil, and minerals are important in agriculture" was true. Twenty-nine respondents (7.2\%) selected false while eight respondents (2.0\%) did not respond. Seventy-seven respondents (19.1\%) did not indicate their level of confidence in their response, while 276 respondents $(68.5 \%)$ were sure of their answer and 50 respondents $(12.4 \%)$ were unsure of their answer (see Table 24). 
Table 24

Responses to Agricultural Knowledge Statements - Environmental and Natural Resources Agricultural Literacy

\begin{tabular}{|c|c|c|c|c|c|c|c|c|c|c|c|c|}
\hline & \multicolumn{2}{|c|}{ No Response } & \multicolumn{2}{|c|}{ True } & \multicolumn{2}{|c|}{ False } & \multicolumn{2}{|c|}{ No Response } & \multicolumn{2}{|c|}{ Sure } & \multicolumn{2}{|c|}{ Unsure } \\
\hline & $\mathrm{N}$ & $\%$ & $\mathrm{~N}$ & $\%$ & $\mathrm{~N}$ & $\%$ & $\mathrm{~N}$ & $\%$ & $\mathrm{~N}$ & $\%$ & $\mathrm{~N}$ & $\%$ \\
\hline $\begin{array}{l}\text { Soil erosion does NOT pollute US } \\
\text { lakes and rivers }\end{array}$ & 9 & 2.2 & 59 & 14.6 & 335 & 83.1 & 76 & 18.9 & 216 & 53.6 & 111 & 27.5 \\
\hline $\begin{array}{l}\text { The use of pesticides has increased } \\
\text { the yield of crops }\end{array}$ & 18 & 4.5 & 288 & 71.5 & 97 & 24.1 & 67 & 16.6 & 148 & 36.7 & 188 & 46.7 \\
\hline $\begin{array}{l}\text { Many farmers use tillage practices } \\
\text { that conserve the soil }\end{array}$ & 29 & 7.2 & 274 & 68.0 & 100 & 24.8 & 59 & 14.6 & 100 & 24.8 & 244 & 60.5 \\
\hline $\begin{array}{l}\text { Farming and wildlife cannot survive } \\
\text { in the same geographic area }\end{array}$ & 20 & 5.0 & 91 & 22.6 & 292 & 72.5 & 67 & 16.6 & 170 & 42.2 & 166 & 41.2 \\
\hline $\begin{array}{l}\text { Biotechnology has increased the } \\
\text { pest resistance of plants }\end{array}$ & 25 & 6.2 & 310 & 76.9 & 68 & 16.9 & 61 & 15.1 & 161 & 40.0 & 181 & 44.9 \\
\hline $\begin{array}{l}\text { Animal wastes are used to increase } \\
\text { soil fertility }\end{array}$ & 13 & 3.2 & 361 & 89.6 & 29 & 7.2 & 71 & 17.6 & 232 & 57.6 & 100 & 24.8 \\
\hline $\begin{array}{l}\text { Water, soil, and minerals are } \\
\text { important in agriculture }\end{array}$ & 8 & 2.0 & 366 & 90.8 & 29 & 7.2 & 77 & 19.1 & 276 & 68.5 & 50 & 12.4 \\
\hline
\end{tabular}




\section{Environmental and Natural Resources Agricultural Literacy Comparison by Groups}

The 403 student respondents were divided into two groups: Davis College Respondents $(n=114)$ and Non-Davis College Respondents $(n=284)$ for the first analysis. The 403 student respondents were divided into two different groups: agricultural background respondents $(n=129)$ and non-agricultural background respondents $(n=274)$ for a second analysis. A composite score was calculated by adding the responses to the seven statements in this category $(1=$ correct answer, $0=$ incorrect answer). The $t$-test statistical procedures were used to determine if statistical differences existed in the means of each of the comparison groups for Environmental and Natural Resources Agricultural Literacy (ENRAL). The following sets of hypotheses were tested:

$\mathrm{H}_{0}=M_{\text {Davis College ENRAL }}=M_{\text {Non-Davis College ENRAL }}$

$\mathrm{H}_{1}=M_{\text {Davis College ENRAL }} \neq M_{\text {Non-Davis College ENRAL }}$

and

$\mathrm{H}_{0}=M_{\text {Agricultural Background ENRAL }}=M_{\text {Non-Agricultural Background ENRAL }}$

$\mathrm{H}_{1}=M_{\text {Agricultural Background ENRAL }} \neq M_{\text {Non-Agricultural Background ENRAL }}$

The maximum score possible for the true and false questions pertaining to the Environmental and Natural Resources Agricultural Literacy statements was seven and a mean score of 5.52 with a standard deviation of 1.38 was found for all 403 respondents. The mean overall score of Davis College Respondents was 5.92 with a standard deviation of 1.21. The mean overall score of Non-Davis College Respondents was 5.36 with a standard deviation of 1.43. The mean overall score of Agricultural Background Respondents was 5.81 with a standard deviation of 1.20 . The mean overall score of Non- 
Agricultural Background Respondents was 5.39 with a standard deviation of 1.44 (see Table 25).

Independent $t$-test statistical analysis procedures were used to compare the means of each of the two groups, Davis College and Non-Davis College Respondents, and Agricultural and Non-Agricultural Background Respondents for Environmental and Natural Resources Agricultural Literacy. The statistical analysis results (Davis/NonDavis College: $t=4.007, \mathrm{df}=245$; Agricultural/Non-Agricultural Background: $t=3.037$, $\mathrm{df}=297$ ) were significant at $\alpha \leq 0.05$. Both null hypothesis were rejected and the research hypotheses, $\mathrm{H}_{1}=M_{\text {Davis College ENRAL }} \neq M_{\text {Non-Davis College ENRAL }}$ and $\mathrm{H}_{1}=M_{\text {Agricultural }}$ Background ENRAL $\neq M_{\text {Non-Agricultural Background ENRAL }}$, were accepted. Davis College majors scored higher on the Environmental and Natural Resources Agricultural Literacy statements than their Non-Davis College counterparts. Students with an agricultural background scored higher on the Environmental and Natural Resources Agricultural Literacy statements than students without an agricultural background. The difference between the mean scores for Environmental and Natural Resources Agricultural Literacy of the Davis College/Non-Davis College group exhibited a small effect size $(d=.30)$ and the difference between the mean scores for Environmental and Natural Resources Agricultural Literacy of the Agricultural/Non-Agricultural Background group exhibited a small effect size $(d=.22)$ (Cohen, 1988). 
Table 25

Environmental and Natural Resources Agricultural Literacy Scores

\begin{tabular}{lccccc}
\hline & $N$ & $M^{1}$ & $S D$ & $d f$ & $t$ \\
\hline All Respondents & 403 & 5.52 & 1.38 & & $4.007^{*}$ \\
\hline Davis College Respondents & 114 & 5.92 & 1.21 & 245 & \\
$\begin{array}{l}\text { Non-Davis College } \\
\text { Respondents }\end{array}$ & 284 & 5.36 & 1.43 & & $3.037^{*}$ \\
\hline $\begin{array}{l}\text { Agricultural Background } \\
\text { Respondents }\end{array}$ & 129 & 5.81 & 1.20 & 297 & \\
$\begin{array}{l}\text { Non-Agricultural Background } \\
\text { Respondents }\end{array}$ & 274 & 5.39 & 1.44 & & \\
$\begin{array}{l}* \alpha \leq 0.05 \\
{ }^{1} \text { Maximum score }=7\end{array}$ & & & & & \\
\end{tabular}

\section{Overall Agricultural Literacy Scores}

An overall composite score for Agricultural Literacy was calculated by adding the responses to all 35 statements in this category $(1=$ correct answer, $0=$ incorrect answer $)$. The 403 student respondents were divided into two groups: Davis College Respondents ( $n=114)$ and Non-Davis College Respondents $(n=284)$ for the first analysis. The 403 student respondents were divided into two different groups: agricultural background respondents $(n=129)$ and non-agricultural background respondents $(n=274)$ for the second analysis. The $t$-test statistical procedures were used to determine if statistical differences existed in the means of each of the comparison groups for Overall Agricultural Literacy Scores. The following sets of hypotheses were tested:

$$
\begin{aligned}
& \mathrm{H}_{0}=M_{\text {Davis College OAL }}=M_{\text {Non-Davis College OAL }} \\
& \mathrm{H}_{1}=M_{\text {Davis College OAL }} \neq M_{\text {Non-Davis College OAL }}
\end{aligned}
$$

and 
$\mathrm{H}_{0}=M_{\text {Agricultural Background OAL }}=M_{\text {Non-Agricultural Background OAL }}$

$\mathrm{H}_{1}=M_{\text {Agricultural Background OAL }} \neq M_{\text {Non-Agricultural Background OAL }}$

The maximum score possible for all of the true and false questions (Overall Agricultural Literacy) was 35 . The 403 respondents had a mean score of 24.31 with a standard deviation of 5.06. The mean overall score of Davis College Respondents was 26.39 with a standard deviation of 4.91. The mean overall score of Non-Davis College Respondents was 23.46 with a standard deviation of 4.92 . The mean overall score of Agricultural Background Respondents was 25.73 with a standard deviation of 4.82 . The mean overall score of Non-Agricultural Background Respondents was 23.64 with a standard deviation of 5.04 (see Table 26).

Independent $t$-test statistical analysis procedures were used to compare the means of each of the two groups, Davis College and Non-Davis College Respondents, and Agricultural and Non-Agricultural Background Respondents. The statistical analysis results (Davis/Non-Davis College: $t=5.374, \mathrm{df}=396$; Agricultural/Non-Agricultural Background: $t=3.946, \mathrm{df}=401$ ) were significant at $\alpha \leq 0.05$. Both null hypothesis were rejected and the research hypotheses, $\mathrm{H}_{1}=M_{\text {Davis College OAL }} \neq M_{\text {Non-Davis College OAL }}$ and $\mathrm{H}_{1}=$ $M_{\text {Agricultural Background OAL }} \neq M_{\text {Non-Agricultural Background OAL }}$, were accepted. Davis College majors scored higher on the Overall Agricultural Literacy statements than their NonDavis College counterparts. Students with an agricultural background scored higher on the Overall Agricultural Literacy statements than students without an agricultural background. The difference between the mean scores of the Davis College/Non-Davis College group exhibited a small $(d=.12)$ effect size and the difference between the mean 
scores of the Agricultural/Non-Agricultural Background group exhibited a small $(d=.08)$ effect size (Cohen, 1988.)

Table 26

Overall Agricultural Literacy Scores

\begin{tabular}{lccccc}
\hline & $N$ & $M^{1}$ & $S D$ & $d f$ & $t$ \\
\hline All Respondents & 403 & 24.31 & 5.06 & & $5.374^{*}$ \\
\hline Davis College Respondents & 114 & 26.39 & 4.91 & 396 & \\
$\begin{array}{l}\text { Non-Davis College } \\
\text { Respondents }\end{array}$ & 284 & 23.46 & 4.92 & & $3.946^{*}$ \\
\hline $\begin{array}{l}\text { Agricultural Background } \\
\text { Respondents }\end{array}$ & 129 & 25.73 & 4.82 & 401 & \\
$\begin{array}{l}\text { Non-Agricultural Background } \\
\text { Respondents }\end{array}$ & 274 & 23.64 & 5.04 & & \\
\hline
\end{tabular}

$* \alpha \leq 0.05$

${ }^{1}$ Maximum score $=35$

\section{Agricultural Knowledge Perceptions}

Respondents in the study were asked to rate their opinion of 35 agricultural knowledge perceptions questions by using a Likert scale. Respondents were instructed to circle the letter that most accurately corresponded to their opinion on the scale which included 1 = Strongly Agree (SA), 2 = Agree (A), $3=$ Neutral (N), 4 = Disagree (D), and $5=$ Strongly Disagree (SD).

The first statement, "US citizens spend a higher percent of their income on food than in other countries," received neutral responses from 33 students $(8.2 \%)$ and three respondents $(.7 \%)$ failed to provide a response. One hundred and forty-three respondents (35.5\%) strongly agreed with the statement and 201 respondents (49.9\%) agreed with the 
statement. Nine respondents $(2.2 \%)$ strongly disagreed with the statement and 14 respondents (3.5\%) disagreed with the statement (see Table 27).

Respondents were asked to respond to "Agriculture employs a large number of people in this country." Sixty-six respondents (16.4\%) strongly agreed with the statement and 142 individuals (35.2\%) agreed with the statement. Thirteen $(3.2 \%)$ strongly disagreed with the statement and 73 respondents $(18.1 \%)$ disagreed with the statement. One hundred five $(26.1 \%)$ respondents had neutral responses and four $(1.0 \%)$ respondents failed to provide a response (see Table 27).

Thirty-four respondents $(8.4 \%)$ strongly agreed with the statement "Pesticides can be used safely when producing food" and 159 (39.5\%) agreed with the statement. Seventy-nine (19.6\%) strongly disagreed with the statement and 26 respondents $(6.5 \%)$ disagreed with the statement. Ninety-nine (24.6\%) respondents had neutral responses and six (1.5\%) respondents failed to provide a response (see Table 27).

"Organic production methods are a realistic alternative to using pesticides" had 83 respondents $(20.6 \%)$ who strongly agreed with the statement while 259 individuals (39.5\%) agreed with the statement. Seven (1.7\%) strongly disagreed with the statement and 29 respondents $(7.2 \%)$ disagreed with the statement. One hundred twenty (29.8\%) respondents had neutral responses and five $(1.2 \%)$ respondents failed to provide a response (see Table 27).

"Confinement is an acceptable practice when raising livestock," received neutral responses from 150 students $(37.2 \%)$ and four respondents $(1.0 \%)$ failed to provide a response. Nineteen respondents (4.7\%) strongly agreed with the statement and 76 respondents (18.9\%) agreed with the statement. Fifty-eight respondents (14.4\%) strongly 
disagreed with the statement and 96 respondents (23.8\%) disagreed with the statement (see Table 27).

Forty-seven respondents (11.7\%) strongly agreed with the statement "Consumers prefer processed foods to raw products" and 129 (32.0\%) agreed with the statement. Twenty-eight (6.9\%) strongly disagreed with the statement and 80 respondents (19.9\%) disagreed with the statement. One hundred twelve (27.8\%) respondents had neutral responses and seven (1.7\%) respondents failed to provide a response (see Table 27).

"Developing countries need help to be able to store food safely" had 125 respondents (31.0\%) who strongly agreed with the statement while 187 individuals $(46.4 \%)$ agreed to the statement. Nineteen respondents $(4.7 \%)$ disagreed with the statement. One hundred eighty-seven (46.4\%) respondents had neutral responses and three $(0.7 \%)$ respondents failed to provide a response (see Table 27$)$.

"People are moving away from rural areas due to changes in agriculture," received neutral responses from 143 students (35.5\%) and five respondents (1.2\%) failed to provide a response. Forty respondents $(9.9 \%)$ strongly agreed with the statement and 132 respondents (32.8\%) agreed with the statement. Fourteen respondents (3.5\%) strongly disagreed with the statement and 69 respondents (17.1\%) disagreed with the statement (see Table 27).

Seven respondents (1.7\%) strongly agreed with the statement "Farmers earn too much money" and 16 (4.0\%) agreed with the statement. One hundred twenty-five (31.0\%) strongly disagreed with the statement and 158 respondents (39.2\%) disagreed with the statement. Ninety-three (23.1\%) respondents had neutral responses and four $(1.0 \%)$ respondents failed to provide a response (see Table 27). 
"Not all land is suitable for farming" found 152 respondents (37.7\%) who strongly agreed with the statement while 204 individuals (50.6\%) agreed with the statement. Four (1.0\%) strongly disagreed with the statement and nine respondents (2.2\%) disagreed with the statement. Two hundred four (50.6\%) respondents had neutral responses and four (1.0\%) respondents failed to provide a response (see Table 27).

"Biotechnology has increased the yield of crops in developing countries," received neutral responses from 192 students $(47.6 \%)$ and six respondents (1.5\%) failed to provide a response. Forty-three respondents (10.7\%) strongly agreed with the statement and 192 respondents (47.6\%) agreed with the statement. Four respondents (1.0\%) strongly disagreed with the statement and 19 respondents (4.7\%) disagreed with the statement (see Table 27).

Thirty respondents (7.4\%) strongly agreed with the statement "Farmers take good care of their animals," and 140 (34.7\%) agreed with the statement. Thirteen (3.2\%) strongly disagreed with the statement and 35 respondents (8.7\%) disagreed with the statement. One hundred eighty (44.7\%) respondents had neutral responses and five (1.2\%) respondents failed to provide a response (see Table 27).

"Processing adds value to farm products" had 21 respondents (5.2\%) who strongly agreed with the statement while 133 individuals (33.0\%) agreed to the statement. Eight (2.0\%) strongly disagreed with the statement and 63 respondents (15.6\%) disagreed with the statement. One hundred seventy-four (43.2\%) respondents had neutral responses and four $(1.0 \%)$ respondents failed to provide a response (see Table 27).

"Farmers should develop new and innovative marketing strategies," received neutral responses from 141 students $(35.0 \%)$ and four respondents (1.0\%) failed to 
provide a response. Thirty-seven respondents $(9.2 \%)$ strongly agreed with the statement and 181 respondents $(44.9 \%)$ agreed with the statement. Four respondents $(1.0 \%)$ strongly disagreed with the statement and 36 respondents (8.9\%) disagreed with the statement (see Table 27).

Thirty respondents (7.4\%) strongly agreed with the statement "A strong agricultural industry is more important than military power" and $88(21.8 \%)$ agreed with the statement. Forty-one (10.2\%) strongly disagreed with the statement and 74 respondents (18.4\%) disagreed with the statement. One hundred sixty-six (41.2\%) respondents had neutral responses and four (1.0\%) respondents failed to provide a response (see Table 27).

"Agricultural exports help to reduce the US trade deficit" received 36 respondents (8.9\%) who strongly agreed with the statement while 167 individuals (41.4\%) agreed to the statement. Four (1.0\%) strongly disagreed with the statement and 30 respondents (7.4\%) disagreed with the statement. One hundred sixty-six (41.2\%) respondents had neutral responses (see Table 27).

"Agricultural practices are harmful to the environment," received neutral responses from 148 students (36.7\%). Nine respondents (2.2\%) strongly agreed with the statement and 49 respondents (12.2\%) agreed with the statement. Forty-eight respondents (11.9\%) strongly disagreed with the statement and 149 respondents $(37.0 \%)$ disagreed with the statement (see Table 27).

Twenty-six respondents (6.5\%) strongly agreed with the statement "Raising hybrid plants results in higher yields" and 132 (32.8\%) agreed with the statement. Six $(1.5 \%)$ strongly disagreed with the statement and 28 respondents $(6.9 \%)$ disagreed with 
the statement. Two hundred eight (51.6\%) respondents had neutral responses and three $(0.7 \%)$ respondents failed to provide a response (see Table 27).

"Farmers are concerned about the humane treatment of animals" received 36 respondents $(8.9 \%)$ who strongly agreed with the statement while 153 individuals $(38.0 \%)$ agreed to the statement. Seven $(1.7 \%)$ strongly disagreed with the statement and 71 respondents (17.6\%) disagreed with the statement. One hundred thirty-four (33.3\%) respondents had neutral responses and two $(0.5 \%)$ respondents failed to provide a response (see Table 27).

"Processing food products is a benefit to consumers," received neutral responses from 155 students $(38.5 \%)$ and one respondent $(0.2 \%)$ failed to provide a response. Thirty-three respondents (8.2\%) strongly agreed with the statement and 141 respondents (35.0\%) agreed with the statement. Twenty-one respondents (5.2\%) strongly disagreed with the statement and 52 respondents (12.9\%) disagreed with the statement (see Table 27).

Twenty three respondents (5.7\%) strongly agreed with the statement "The US should allow free trade with other countries for food products" and 114 individuals (28.3\%) agreed with the statement. Twenty-three (5.7\%) strongly disagreed with the statement and 81 respondents (20.1\%) disagreed with the statement. One hundred sixtyone $(40.0 \%)$ respondents had neutral responses and one $(0.2 \%)$ respondents failed to provide a response (see Table 27).

"The world food supply has increased as a result of improved technology" received 46 respondents (11.4\%) who strongly agreed with the statement while 205 individuals (50.9\%) agreed to the statement. Three $(0.7 \%)$ strongly disagreed with the 
statement and 51 respondents (12.7\%) disagreed with the statement. Ninety-seven (24.1\%) respondents had neutral responses and one $(0.2 \%)$ respondents failed to provide a response (see Table 27).

"The US needs a steady supply of food and fiber products to remain strong," received neutral responses from 78 students (19.4\%) and two respondents (0.5\%) failed to provide a response. Sixty-five respondents $(16.1 \%)$ strongly agreed with the statement and 233 respondents (57.8\%) agreed with the statement. Six respondents (1.5\%) strongly disagreed with the statement and 19 respondents (4.7\%) disagreed with the statement (see Table 27).

Thirty-eight respondents (9.4\%) strongly agreed with the statement "Only organic methods should be used to produce food" and $71(17.6 \%)$ agreed with the statement. Thirty (7.4\%) strongly disagreed with the statement and 110 respondents $(27.3 \%)$ disagreed with the statement. One hundred fifty-three (38.0\%) respondents had neutral responses and one $(0.2 \%)$ respondents failed to provide a response (see Table 27).

"Farmers should NOT use chemicals in crop production" received 45 respondents (11.2\%) who strongly agreed with the statement while 103 individuals (25.6\%) agreed to the statement. Sixteen (4.0\%) strongly disagreed with the statement and 81 respondents (20.1\%) disagreed with the statement. One hundred fifty-four (38.2\%) respondents had neutral responses and four (1.0\%) respondents failed to provide a response (see Table 27).

"Animals have the same rights as people," received neutral responses from 130 students $(32.3 \%)$ and four respondents $(1.0 \%)$ failed to provide a response. Forty-three respondents (10.7\%) strongly agreed with the statement and 83 respondents $(20.6 \%)$ 
agreed with the statement. Fifty-five respondents (13.6\%) strongly disagreed with the statement and 88 respondents (21.8\%) disagreed with the statement (see Table 27).

Forty respondents (9.9\%) strongly agreed with the statement "Processing adds more to the cost of food than the raw product" and $161(40.0 \%)$ agreed with the statement. Eight (2.0\%) strongly disagreed with the statement and 40 respondents $(9.9 \%)$ disagreed with the statement. One hundred forty-nine (37.0\%) respondents had neutral responses and five (1.2\%) respondents failed to provide a response (see Table 27).

"Farmers have no control over food prices" received 18 respondents (4.5\%) who strongly agreed with the statement while 112 individuals (27.8\%) agreed to the statement. Twenty (5.0\%) strongly disagreed with the statement and 110 respondents (27.3\%) disagreed with the statement. One hundred thirty-nine (34.5\%) respondents had neutral responses and four (1.0\%) respondents failed to provide a response (see Table 27).

"Developing countries lack the ability to produce enough food," received neutral responses from 120 students $(29.8 \%)$ and two respondents $(0.5 \%)$ failed to provide a response. Forty-five respondents (11.2\%) strongly agreed with the statement and 189 respondents (46.9\%) agreed with the statement. Five respondents (1.2\%) strongly disagreed with the statement and 42 respondents (10.4\%) disagreed with the statement (see Table 27).

Eleven respondents (2.7\%) strongly agreed with the statement "The government should exert more control over farming" and 74 (18.4\%) agreed with the statement. Thirty-one (7.7\%) strongly disagreed with the statement and 93 respondents (23.1\%) disagreed with the statement. One hundred ninety-two (47.6\%) respondents had neutral responses and two $(0.5 \%)$ respondents failed to provide a response (see Table 27). 
"Agriculture is the greatest polluter of our water supplies" received 21 respondents (5.2\%) who strongly agreed with the statement while 59 individuals (14.6\%) agreed to the statement. Fifty-five (13.6\%) strongly disagreed with the statement and 128 respondents (31.8\%) disagreed with the statement. One hundred thirty-nine (34.5\%) respondents had neutral responses and one $(0.2 \%)$ respondent failed to provide a response (see Table 27).

"Agriculture has become too mechanized," received neutral responses from 184 students $(45.7 \%)$ and one respondent $(0.2 \%)$ failed to provide a response. Fourteen respondents (3.5\%) strongly agreed with the statement and 64 respondents $(15.9 \%)$ agreed with the statement. Twenty-three respondents (5.7\%) strongly disagreed with the statement and 117 respondents (29.0\%) disagreed with the statement (see Table 27).

Fourteen respondents (3.5\%) strongly agreed with the statement "Animals should NOT be used for food" and 20 individuals (5.0\%) agreed with the statement. One hundred ninety-eight (49.1\%) strongly disagreed with the statement and 114 respondents (28.3\%) disagreed with the statement. Fifty-four (13.4\%) respondents had neutral responses and three $(0.7 \%)$ respondents failed to provide a response (see Table 27$)$.

"Farm grains are becoming an important energy source in the US" received 31 respondents (7.7\%) who strongly agreed with the statement while 194 individuals (48.1\%) agreed to the statement. Three $(0.7 \%)$ strongly disagreed with the statement and 21 respondents (5.2\%) disagreed with the statement. One hundred fifty-two (37.7\%) respondents had neutral responses and two $(0.5 \%)$ respondents failed to provide a response (see Table 27). 
Table 27

Responses to Agricultural Perceptions Statements

\begin{tabular}{|c|c|c|c|c|c|c|c|c|c|c|c|c|}
\hline & \multicolumn{2}{|c|}{ No Response } & \multicolumn{2}{|c|}{$\begin{array}{l}\text { Strongly } \\
\text { Agree }\end{array}$} & \multicolumn{2}{|c|}{ Agree } & \multicolumn{2}{|c|}{ Neutral } & \multicolumn{2}{|c|}{ Disagree } & \multicolumn{2}{|c|}{$\begin{array}{l}\text { Strongly } \\
\text { Disagree }\end{array}$} \\
\hline & $\mathrm{N}$ & $\%$ & $\mathrm{~N}$ & $\%$ & $\mathrm{~N}$ & $\%$ & $\mathrm{~N}$ & $\%$ & $\mathrm{~N}$ & $\%$ & $\mathrm{~N}$ & $\%$ \\
\hline $\begin{array}{l}\text { US citizens spend a higher percent of their } \\
\text { income on food than in other countries }\end{array}$ & 3 & .7 & 143 & 35.5 & 201 & 49.9 & 33 & 8.2 & 14 & 3.5 & 9 & 2.2 \\
\hline $\begin{array}{l}\text { Agriculture employs a large number of } \\
\text { people in this country }\end{array}$ & 4 & 1.0 & 66 & 16.4 & 142 & 35.2 & 105 & 26.1 & 73 & 18.1 & 13 & 3.2 \\
\hline $\begin{array}{l}\text { Pesticides can be used safely when } \\
\text { producing food }\end{array}$ & 6 & 1.5 & 34 & 8.4 & 159 & 39.5 & 99 & 24.6 & 79 & 19.6 & 26 & 6.5 \\
\hline $\begin{array}{l}\text { Organic production methods are a realistic } \\
\text { alternative to using pesticides }\end{array}$ & 5 & 1.2 & 83 & 20.6 & 159 & 39.5 & 120 & 29.8 & 29 & 7.2 & 7 & 1.7 \\
\hline $\begin{array}{l}\text { Confinement is an acceptable practice } \\
\text { when raising livestock }\end{array}$ & 4 & 1.0 & 19 & 4.7 & 76 & 18.9 & 150 & 37.2 & 96 & 23.8 & 58 & 14.4 \\
\hline $\begin{array}{l}\text { Consumers prefer processed foods to raw } \\
\text { products }\end{array}$ & 7 & 1.7 & 47 & 11.7 & 129 & 32.0 & 112 & 27.8 & 80 & 19.9 & 28 & 6.9 \\
\hline $\begin{array}{l}\text { Developing countries need help to be able } \\
\text { to store food safely }\end{array}$ & 3 & .7 & 125 & 31.0 & 187 & 46.4 & 69 & 17.1 & 19 & 4.7 & 0 & 0.0 \\
\hline
\end{tabular}


Table 27 (Continued)

Responses to Agricultural Perceptions Statements

\begin{tabular}{|c|c|c|c|c|c|c|c|c|c|c|c|c|}
\hline & \multicolumn{2}{|c|}{ No Response } & \multicolumn{2}{|c|}{$\begin{array}{l}\text { Strongly } \\
\text { Agree }\end{array}$} & \multicolumn{2}{|c|}{ Agree } & \multicolumn{2}{|c|}{ Neutral } & \multicolumn{2}{|c|}{ Disagree } & \multicolumn{2}{|c|}{$\begin{array}{l}\text { Strongly } \\
\text { Disagree }\end{array}$} \\
\hline & $\mathrm{N}$ & $\%$ & $\mathrm{~N}$ & $\%$ & $\mathrm{~N}$ & $\%$ & $\mathrm{~N}$ & $\%$ & $\mathrm{~N}$ & $\%$ & $\mathrm{~N}$ & $\%$ \\
\hline $\begin{array}{l}\text { People are moving away from rural areas } \\
\text { due to changes in agriculture }\end{array}$ & 5 & 1.2 & 40 & 9.9 & 132 & 32.8 & 143 & 35.5 & 69 & 17.1 & 14 & 3.5 \\
\hline Farmers earn too much money & 4 & 1.0 & 7 & 1.7 & 16 & 4.0 & 93 & 23.1 & 158 & 39.2 & 125 & 31.0 \\
\hline Not all land is suitable for farming & 4 & 1.0 & 152 & 37.7 & 204 & 50.6 & 30 & 7.4 & 9 & 2.2 & 4 & 1.0 \\
\hline $\begin{array}{l}\text { Biotechnology has increased the yield of } \\
\text { crops in developing countries }\end{array}$ & 6 & 1.5 & 43 & 10.7 & 192 & 47.6 & 139 & 34.5 & 19 & 4.7 & 4 & 1.0 \\
\hline Farmers take good care of their animals & 5 & 1.2 & 30 & 7.4 & 140 & 34.7 & 180 & 44.7 & 35 & 8.7 & 13 & 3.2 \\
\hline Processing adds value to farm products & 4 & 1.0 & 21 & 5.2 & 133 & 33.0 & 174 & 43.2 & 63 & 15.6 & 8 & 2.0 \\
\hline $\begin{array}{l}\text { Farmers should develop new and } \\
\text { innovative marketing strategies }\end{array}$ & 4 & 1.0 & 37 & 9.2 & 181 & 44.9 & 141 & 35.0 & 36 & 8.9 & 4 & 1.0 \\
\hline $\begin{array}{l}\text { A strong agricultural industry is more } \\
\text { important than military power }\end{array}$ & 4 & 1.0 & 30 & 7.4 & 88 & 21.8 & 166 & 41.2 & 74 & 18.4 & 41 & 10.2 \\
\hline $\begin{array}{l}\text { Agricultural exports help to reduce the US } \\
\text { trade deficit }\end{array}$ & 0 & 0.0 & 36 & 8.9 & 167 & 41.4 & 166 & 41.2 & 30 & 7.4 & 4 & 1.0 \\
\hline
\end{tabular}


Table 27 (Continued)

Responses to Agricultural Perceptions Statements

\begin{tabular}{|c|c|c|c|c|c|c|c|c|c|c|c|c|}
\hline & \multicolumn{2}{|c|}{ No Response } & \multicolumn{2}{|c|}{$\begin{array}{l}\text { Strongly } \\
\text { Agree }\end{array}$} & \multicolumn{2}{|c|}{ Agree } & \multicolumn{2}{|c|}{ Neutral } & \multicolumn{2}{|c|}{ Disagree } & \multicolumn{2}{|c|}{$\begin{array}{l}\text { Strongly } \\
\text { Disagree }\end{array}$} \\
\hline & $\mathrm{N}$ & $\%$ & $\mathrm{~N}$ & $\%$ & $\mathrm{~N}$ & $\%$ & $\mathrm{~N}$ & $\%$ & $\mathrm{~N}$ & $\%$ & $\mathrm{~N}$ & $\%$ \\
\hline $\begin{array}{l}\text { Agricultural practices are harmful to the } \\
\text { environment }\end{array}$ & 0 & 0.0 & 9 & 2.2 & 49 & 12.2 & 148 & 36.7 & 149 & 37.0 & 48 & 11.9 \\
\hline $\begin{array}{l}\text { Raising hybrid plants results in higher } \\
\text { yields }\end{array}$ & 3 & .7 & 26 & 6.5 & 132 & 32.8 & 208 & 51.6 & 28 & 6.9 & 6 & 1.5 \\
\hline $\begin{array}{l}\text { Farmers are concerned about the humane } \\
\text { treatment of animals }\end{array}$ & 2 & .5 & 36 & 8.9 & 153 & 38.0 & 134 & 33.3 & 71 & 17.6 & 7 & 1.7 \\
\hline $\begin{array}{l}\text { Processing food products is a benefit to } \\
\text { consumers }\end{array}$ & 1 & .2 & 33 & 8.2 & 141 & 35.0 & 155 & 38.5 & 52 & 12.9 & 21 & 5.2 \\
\hline $\begin{array}{l}\text { The US should allow free trade with other } \\
\text { countries for food products }\end{array}$ & 1 & .2 & 23 & 5.7 & 114 & 28.3 & 161 & 40.0 & 81 & 20.1 & 23 & 5.7 \\
\hline $\begin{array}{l}\text { The world food supply has increased as a } \\
\text { result of improved technology }\end{array}$ & 1 & .2 & 46 & 11.4 & 205 & 50.9 & 97 & 24.1 & 51 & 12.7 & 3 & .7 \\
\hline $\begin{array}{l}\text { The US needs a steady supply of food and } \\
\text { fiber products to remain strong }\end{array}$ & 2 & .5 & 65 & 16.1 & 233 & 57.8 & 78 & 19.4 & 19 & 4.7 & 6 & 1.5 \\
\hline
\end{tabular}


Table 27 (Continued)

Responses to Agricultural Perceptions Statements

\begin{tabular}{|c|c|c|c|c|c|c|c|c|c|c|c|c|}
\hline & \multicolumn{2}{|c|}{ No Response } & \multicolumn{2}{|c|}{$\begin{array}{l}\text { Strongly } \\
\text { Agree }\end{array}$} & \multicolumn{2}{|c|}{ Agree } & \multicolumn{2}{|c|}{ Neutral } & \multicolumn{2}{|c|}{ Disagree } & \multicolumn{2}{|c|}{$\begin{array}{l}\text { Strongly } \\
\text { Disagree }\end{array}$} \\
\hline & $\mathrm{N}$ & $\%$ & $\mathrm{~N}$ & $\%$ & $\mathrm{~N}$ & $\%$ & $\mathrm{~N}$ & $\%$ & $\mathrm{~N}$ & $\%$ & $\mathrm{~N}$ & $\%$ \\
\hline $\begin{array}{l}\text { Only organic methods should be used to } \\
\text { produce food }\end{array}$ & 1 & .2 & 38 & 9.4 & 71 & 17.6 & 153 & 38.0 & 110 & 27.3 & 30 & 7.4 \\
\hline $\begin{array}{l}\text { Farmers should NOT use chemicals in crop } \\
\text { production }\end{array}$ & 4 & 1.0 & 45 & 11.2 & 103 & 25.6 & 154 & 38.2 & 81 & 20.1 & 16 & 4.0 \\
\hline Animals have the same rights as people & 4 & 1.0 & 43 & 10.7 & 83 & 20.6 & 130 & 32.3 & 88 & 21.8 & 55 & 13.6 \\
\hline $\begin{array}{l}\text { Processing adds more to the cost of food } \\
\text { than the raw product }\end{array}$ & 5 & 1.2 & 40 & 9.9 & 161 & 40.0 & 149 & 37.0 & 40 & 9.9 & 8 & 2.0 \\
\hline Farmers have no control over food prices & 4 & 1.0 & 18 & 4.5 & 112 & 27.8 & 139 & 34.5 & 110 & 27.3 & 20 & 5.0 \\
\hline $\begin{array}{l}\text { Developing countries lack the ability to } \\
\text { produce enough food }\end{array}$ & 2 & .5 & 45 & 11.2 & 189 & 46.9 & 120 & 29.8 & 42 & 10.4 & 5 & 1.2 \\
\hline $\begin{array}{l}\text { The government should exert more control } \\
\text { over farming }\end{array}$ & 2 & .5 & 11 & 2.7 & 74 & 18.4 & 192 & 47.6 & 93 & 23.1 & 31 & 7.7 \\
\hline $\begin{array}{l}\text { Agriculture is the greatest polluter of our } \\
\text { water supplies }\end{array}$ & 1 & .2 & 21 & 5.2 & 59 & 14.6 & 139 & 34.5 & 128 & 31.8 & 55 & 13.6 \\
\hline
\end{tabular}


Table 27 (Continued)

Responses to Agricultural Perceptions Statements

\begin{tabular}{|c|c|c|c|c|c|c|c|c|c|c|c|c|}
\hline & \multicolumn{2}{|c|}{ No Response } & \multicolumn{2}{|c|}{$\begin{array}{l}\text { Strongly } \\
\text { Agree }\end{array}$} & \multicolumn{2}{|c|}{ Agree } & \multicolumn{2}{|c|}{ Neutral } & \multicolumn{2}{|c|}{ Disagree } & \multicolumn{2}{|c|}{$\begin{array}{l}\text { Strongly } \\
\text { Disagree }\end{array}$} \\
\hline & $\mathrm{N}$ & $\%$ & $\mathrm{~N}$ & $\%$ & $\mathrm{~N}$ & $\%$ & $\mathrm{~N}$ & $\%$ & $\mathrm{~N}$ & $\%$ & $\mathrm{~N}$ & $\%$ \\
\hline Agriculture has become too mechanized & 1 & .2 & 14 & 3.5 & 64 & 15.9 & 184 & 45.7 & 117 & 29.0 & 23 & 5.7 \\
\hline Animals should NOT be used for food & 3 & .7 & 14 & 3.5 & 20 & 5.0 & 54 & 13.4 & 114 & 28.3 & 198 & 49.1 \\
\hline $\begin{array}{l}\text { Farm grains are becoming an important } \\
\text { energy source in the US }\end{array}$ & 2 & .5 & 31 & 7.7 & 194 & 48.1 & 152 & 37.7 & 21 & 5.2 & 3 & .7 \\
\hline $\begin{array}{l}\text { Developing countries need help in } \\
\text { distributing food among needy people }\end{array}$ & 2 & .5 & 79 & 19.6 & 206 & 51.1 & 94 & 23.3 & 12 & 3.0 & 10 & 2.5 \\
\hline
\end{tabular}


"Developing countries need help in distributing food among needy people," received neutral responses from 94 students $(23.3 \%)$ and two respondents $(0.5 \%)$ failed to provide a response. Seventy-nine respondents (19.6\%) strongly agreed with the statement and 206 respondents (51.1\%) agreed with the statement. Ten respondents (2.5\%) strongly disagreed with the statement and 12 respondents $(3.0 \%)$ disagreed with the statement (see Table 27).

Agricultural Literacy Perception Scores

The 403 student respondents were divided into two groups: Davis College Respondents $(n=114)$ and Non-Davis College Respondents $(n=284)$ for the first analysis. The 403 student respondents were divided into two different groups: agricultural background respondents $(n=129)$ and non-agricultural background respondents $(n=274)$ for the second analysis. A composite score was calculated by averaging the responses to the 35 statements in this category. The $t$-test statistical procedures were used to determine if statistical differences existed in the means of each of the comparison groups for Agricultural Literacy Perceptions (ALP). The following sets of hypotheses were tested:

$\mathrm{H}_{0}=M_{\text {Davis College ALP }}=M_{\text {Non-Davis College ALP }}$

$\mathrm{H}_{1}=M_{\text {Davis College ALP }} \neq M_{\text {Non-Davis College ALP }}$

and

$\mathrm{H}_{0}=M_{\text {Agricultural Background ALP }}=M_{\text {Non-Agricultural Background ALP }}$

$\mathrm{H}_{1}=M_{\text {Agricultural Background ALP }} \neq M_{\text {Non-Agricultural Background ALP }}$

The Agricultural Literacy Perceptions portion of the instrument consisted of 35 statements. Respondents were directed to rate their responses to the statements using a 
Likert scale ranging from Strongly Agree (1) to Agree (2) to Neutral (3) to Disagree (4) to Strongly Disagree (5). A mean score of 2.67 with a standard deviation of 0.28 was found for all 403 respondents. The mean score of Davis College Respondents was 2.55 with a standard deviation of 0.29 . The mean overall score of Non-Davis College Respondents was 2.71 with a standard deviation of 0.26 . The mean overall score of Agricultural Background Respondents was 2.58 with a standard deviation of 0.32 . The mean overall score of Non-Agricultural Background Respondents was 2.71 with a standard deviation of 0.26 (see Table 28).

Independent $t$-test statistical analysis procedures were used to compare the means of each of the two groups, Davis College and Non-Davis College Respondents, and Agricultural and Non-Agricultural Background Respondents for Agricultural Literacy Perceptions. The statistical analysis results (Davis/Non-Davis College: $t=-5.569, \mathrm{df}=$ 396; Agricultural/Non-Agricultural Background: $t=-4.046, \mathrm{df}=200$ ) were significant at $\alpha \leq 0.05$. Both null hypothesis were rejected and the research hypotheses, $H_{1}=M_{\text {Davis }}$ College ALP $\neq M_{\text {Non-Davis College ALP }}$ and $\mathrm{H}_{1}=M_{\text {Agricultural Background ALP }} \neq M_{\text {Non-Agricultural Background }}$ ALP, were accepted. Davis College majors scored higher on the Agricultural Literacy Perceptions statements than their Non-Davis College counterparts. Students with an agricultural background scored higher on the Agricultural Literacy Perceptions statements than students without an agricultural background. The difference between the mean scores for Agricultural Literacy Perceptions of the Davis College/Non-Davis College group exhibited a large effect size and the difference between the mean scores for Agricultural Literacy Perceptions of the Agricultural/Non-Agricultural Background group exhibited a large effect size (Cohen, 1988.) 
Table 28

Agricultural Literacy Perceptions Scores

\begin{tabular}{lccccc}
\hline & $N$ & $M^{1}$ & $S D$ & $d f$ & $t$ \\
\hline All Respondents & 403 & 2.67 & 0.28 & & \\
Davis College Respondents & 114 & 2.55 & 0.29 & 396 & $-5.569^{*}$ \\
$\begin{array}{l}\text { Non-Davis College } \\
\text { Respondents }\end{array}$ & 284 & 2.71 & 0.26 & & \\
$\begin{array}{l}\text { Agricultural Background } \\
\text { Respondents }\end{array}$ & 129 & 2.58 & 0.32 & 200 & $-4.046^{*}$ \\
$\begin{array}{l}\text { Non-Agricultural Background } \\
\text { Respondents }\end{array}$ & 274 & 2.71 & 0.25 & & \\
\hline
\end{tabular}

$* \alpha \leq 0.05$

${ }^{1}$ Score Range $=1-5$ 


\section{CHAPTER V}

Summary, Conclusions, and Recommendations

Purpose of the Study

The purpose of this research study was to determine the knowledge of agriculture possessed by incoming freshmen at West Virginia University. Accessible first year students from all majors and colleges within West Virginia University completed a questionnaire which assessed and provided data that illustrated their knowledge of general agricultural related topics.

Objectives of the Study:

The specific objectives of this study were as follows:

1) To assess the level of knowledge of agriculture incoming freshmen possess;

2) To compare the results of knowledge possessed by students with an agricultural background to those students with no agricultural background; and

3) To assess and compare the level of knowledge possessed by students as a collective body from non-agricultural colleges against those students from the agriculture college of West Virginia University.

\section{Summary}

Less than one-third (28.3\%) of the study participants were enrolled in agricultural majors in the Davis College of Agriculture, Forestry, and Consumer Sciences at West Virginia University and less than one-third (28.5\%) of the respondents had worked on a farm or ranch. Student demographic data also revealed that slightly more than one-tenth $(11.9 \%)$ of respondents were enrolled in agriculture classes while in high school and that $39.2 \%$ of respondents' high schools offered agriculture classes. Slightly over $10 \%$ 
$(10.2 \%)$ of respondents grew up on a farm or ranch, while over half $(55.1 \%)$ of the respondents grew up in a city or suburb. Just over one-tenth (11.4\%) of respondents had worked in an agribusiness. When asked if they or a family members had lived or worked on a farm or ranch or worked in an agribusiness, nearly half (49.9\%) indicated they or a family member had lived or worked on a farm or ranch while one-third (33.0\%) had either worked in an agribusiness or had a family member work in an agribusiness.

When asked about agriculture-related organizations, just over half $(50.6 \%)$ of respondents identified 4-H as a program available to them in their community. Over onethird of the respondents (36.0\%) did not know what agriculture-related organizations were available in their community. Between $4 \%$ and $33.5 \%$ of respondents indicated being aware of any of the other choices listed on the questionnaire. Less than one-sixth of the respondents indicated any involvement in agriculture-related organizations such as 4-H (14.9\%), FFA (7.2\%), or other organizations in high school (4.2\%) or college $(6.5 \%)$.

One-third (33.0\%) of respondents correctly identified the definition of a Land Grant University, slightly more than one-third (34.5\%) of respondents were aware that WVU is a Land Grant University, and slightly less than one-half (47.9\%) were aware that WVU owns and operates several farms. Less than ten percent (9.4\%) of students were aware that WVU is not the only Land Grant University in the state of West Virginia.

In the agricultural literacy portion of the instrument, respondents with a major in the Davis College had average scores $(M=26.39)$ higher than individuals with majors outside of the Davis College $(M=23.46)$. Respondents with an agricultural background had higher mean scores in the agricultural literacy portion of the instrument $(M=25.73)$ 
than students without an agricultural background $(M=23.64)$. Similar differences between Davis and non-Davis students and students with agricultural backgrounds and students without agricultural backgrounds were found when the agricultural literacy portion of the instrument was divided into General Agricultural Knowledge, Agricultural Career Literacy, Agricultural Policy Literacy, and Environmental and Natural Resources Agricultural Literacy sections. For each of the four sections, the average scores of Davis College majors were statistically higher than the scores for students with majors outside the college. Students with an agricultural background had statistically higher scores than students who did not have an agricultural background.

Thirty-five Likert scale Agricultural Literacy Perceptions statements were included in the instrument. A lower score indicated a more positive perception of agriculture while a higher score indicated a more negative perception of agriculture. The 403 respondents expressed agreement $(M=2.67)$ with the agricultural literacy perceptions. Davis College respondents $(M=2.55)$ expressed stronger agreement than their Non-Davis College counterparts $(M=2.71)$. Respondents with an agricultural background also expressed a stronger agreement $(M=2.58)$ on the items than NonAgricultural Background respondents $(M=2.71)$.

\section{Conclusions}

Because of data collection procedures used in the study, it was not possible for the researcher to generalize the results of this study to include individuals outside of the 403 student respondents from West Virginia University. Based on the major findings which resulted from this study, the following conclusions about agricultural literacy were reached for the 403 student respondents from West Virginia University. 
1. Freshmen students at West Virginia University possess limited knowledge and understanding of the agricultural industry as a whole.

2. Students with a background in agriculture had higher levels of knowledge and perceptions of agriculture.

3. Those freshmen respondents who are enrolled in a major within the Davis College of Agriculture, Forestry, and Consumer Sciences at West Virginia University exhibit increased levels of agricultural knowledge and perceptions.

4. Although statistically significant differences were found between those freshmen students who have had a greater exposure to agriculture-related experiences and those freshmen who lack such interactions, the researcher failed to establish a practical significance between the scores because the overall scores indicated a limited level of agricultural literacy of behalf of all freshmen respondents.

\section{Discussion}

The findings presented as a result of this researchers efforts are not vastly different than those identified by various other researchers striving to alter the deficit of agricultural illiteracy in today's society. Two individual's research efforts were closely identifiable with this researcher's study. Frick (2005) and Riedel (2006) both used similar instruments in their research.

Riedel (2006) noted an overall agricultural literacy score of 24.13 with a standard deviation of 6.85 , while this researcher found the 403 respondents in this study to have a mean score of 24.31 with a standard deviation of 5.06. In relation to perceptions of agriculture, Riedel's study identified a score of 93 out of 175 , or a score of 2.66 out of five, while this researcher's findings displayed a 2.67 out of five, where anything less 
than three is recognized as reflecting positive attitudes about agriculture and anything greater than three represents more negative attitudes about agriculture.

When comparing Frick's study with this researcher's study, a comparison between students with an agricultural background/without an agricultural background and rural high school students/inner-city high school students can be discussed. The overall agricultural knowledge scores of rural high school students in Frick's study was 22.77 out of 35 and 16.95 out of 35 for inner-city high school students. This researcher's results for agricultural background students found a mean score of 25.73 out of 35 and 23.64 out of 35 for non-agricultural background students. When considering the perceptions scores for these groups, Frick's rural high school student population scored a mean of 83.90 out of 175 , or 2.40 out of five and his inner-city high school population scored a mean of 85.79 out of 175 , or 2.45 out of five. The mean scores for the agricultural background respondents and non-agricultural background respondents in this research effort found mean scores of 2.58 and 2.71 out of five for these two groups, respectively. Although this researcher's scores do not appear as significant as those found by Frick (2005), an obvious difference is apparent between individuals who have an association to a rural and/or agricultural setting and those who lack such interaction.

\section{Recommendations}

The information gathered herein focuses on the ever expanding challenge facing today's agricultural education profession. While utilizing insight gained from available research trends of agricultural literacy, the researcher's opinions developed throughout the process of this study, and the major findings which resulted from this study, the recommendations that follow have been developed. 
1. Focusing efforts on developing and implementing educational programs to increase literacy of agriculture among people of all backgrounds and ages is critical. Beginning in elementary school and continuing throughout all levels of education and societal involvement, programs which inform individuals about their connection to agriculture would result in a society better equipped with basic agricultural knowledge and skills.

2. Land Grant Universities should better preserve and promote their reason for inception through education of those students enrolled in the Universities. The purpose of their development was to provide education primarily in agriculture, military tactics, the mechanic arts, and cooperative extension as well as classical studies. Limited awareness of this fact by freshmen students indicates a gap between meeting the student's desired goals of attending a Land Grant University and the mission of the Land Grant University.

3. Two decades have passed since the National Research Council Committee on Agricultural Education identified the serious nature surrounding the depressed state of agricultural literacy in our country's school systems. Numerous other studies, past and present, including this researcher's findings, have pointed towards an obvious need for change in the level of agricultural awareness among individuals. A more comprehensive form of analysis and attempt to increase agricultural literacy should be enacted to influence positive changes in the current literacy status. 


\section{REFERENCES}

Ary, D., Jacobs, L. C., Razavieh, A., \& Sorensen, C. (2006). Introduction to research in education (7t ed.). California: Thomson Wadsworth.

Bellah, K. A., \& Dyer, J. E. (2007). Elementary teachers' attitudes and stages of concern about an agricultural literacy curriculum. Proceedings $34^{\text {th }}$ Annual National Agricultural Education Research Conference, XXXIV, Minneapolis, MN, 66-81.

Birkenholz, R. J. (1992). Strategies to promote agricultural literacy. 1992 AAAE Ad Hoc Agricultural Literacy Work Group, St. Louis, Missouri.

Birkenholz, R. J., Harris, C. R., \& Pry, H. W. (1994). A pilot study: Assessment of agricultural literacy among college students. National Association of Colleges and Teachers of Agriculture, 38(1), 63-66.

Blackburn, D. A. (1999). Ag science fairs: The next wave in agricultural literacy. Journal of Extension, 37 (4). Retrieved June 8, 2007 from http://www.joe.org/joe/1999august/tt1.html.

Camp, W. G. (2004). Understanding the relationship of school gardens to agricultural literacy in elementary school students. Ithaca, NY: Cornell University, College of Agriculture and Life Sciences. Retrieved June 8, 2007 from http://research.cals.cornell.edu/entity?home $=6 \& \mathrm{id}=16248$.

Cohen, J. (1988). Statistical power analysis for the behavioral sciences $\left(2^{\text {nd }}\right.$ ed.)Hillsdale, NJ: Lawrence Erlbaum Associates.

Doerfert, D. L. (2003). Agricultural literacy: An assessment of research studies published within the agricultural education profession. Lubbock, TX: Texas Tech University. Retrieved August 8, 2007 from http://www.agclassroom.org/consortium/pdf/ag_literacy/2003/ag_literacy.pdf.

Douglas, G. K. (1985). Cultivating agricultural literacy: Challenge for the liberal arts. Battle Creek, Michigan: W. K. Kellogg Foundation.

Frick, M. J., Birkenholz, R. J., Gardner, H., \& Machtmes, K. (1995). Rural and urban inner-city high school student knowledge and perception of agriculture. Journal of Agricultural Education, 36 (4), 1-9.

Frick, M. J. (1990). A definition and the concepts of agricultural literacy: A national study. Unpublished doctoral dissertation, Iowa State University, Ames.

Harris, C. R., \& Birkenholz, R. J. (1996). Agricultural literacy of Missouri secondary school educators. Journal of Agricultural Education, 37 (2), 63-71. 
Leising, J. G. (1998). A guide to food and fiber systems literacy. Stillwater, Oklahoma: Oklahoma State University. Retrieved August 8, 2007 from http://food_fiber.okstate.edu/FINAL1.PDF.

Leising, J. G., Pense, S. L., \& Portillo, M. T. (2003). The impact of selected agriculture in the classroom teachers on student agricultutal literacy. Stillwater, Oklahoma: Oklahoma State University, Department of Agricultural Education, Communications, and 4-H Youth Development.

Mawby, R. G. (1985). Cultivating agricultural literacy: Challenge for the liberal arts. Battle Creek, Michigan: W. K. Kellogg Foundation.,

Moore, G. E. (2000). Achieving 2020: Goal 3: All students are conversationally literate in agriculture, food, fiber, and natural resource systems. The Agricultural Education Magazine, 73 (1), 1-25.

National Center for Education Statistics (NCES). (2005-06). Public elementary and secondary school student enrollment, high school completions, and staff from the common core of data: school year 2005-06. Washington, DC: Author. Retrieved April 6, 2008 from http://nces.ed.gov/pubs2007/pesenroll06/xls/table_1.xls.

National Research Council, Board on Agriculture, Committee on Agricultural Education in Secondary Schools. (1988). Understanding agriculture: New directions for agricultural education. Washington D.C.: National Academy Press. Retrieved June 8, 2007 from http://www.nap.edu/openbook.php?record_id=766\&page=9.

Raven, M. R. (1994). The need for agricultural literacy. Vocational Education Journal, $69(3), 37-38$.

Riedel, J. S. (2006). Effects of an introductory agricultural education course on agricultural literacy and perceptions of agriculture in urban students. Unpublished Master's thesis, North Carolina state University, Raleigh, North Carolina. Retrieved August 16, 2008 from http://www.lib.ncsu.edu/theses/available/etd-07102006-202453/.

Robinson, J. P., Shaver, P. R., \& Wrightsman, L. S. (1991). Criteria for scale selection and evaluation. In J. P. Robinson, P. R. Shaver, \& L. S. Wrightsman (Eds.). Measures of personality and social psychological attitudes (pp. 1-16) New York: Academic Press.

Rossetti, R., \& McCaslin, N. L. (1991). A status report on middle grade agricultural education and FFA programs in the United States. Journal of Agricultural Education, 35 (2), 22-26.

Team Ag Ed. (2000). The National Strategic Plan and Action Agenda for Agricultural Education. Alexandria, VA. Retrieved August 8, 2007 from http://www.teamaged.org/plan2020/plan2020.pdf. 
Team Ag Ed. (n. d. ). 2005-2006 Annual report on agricultural education. Alexandria, VA.

U.S. Census Bureau. (2008). Statistical abstract of the United States: 2004-2005.

Washington, D.C. Retrieved April 6, 2008, from

http://www.census.gov/prod/2004pubs/04statab/pop.pdf.

United States Department of Agriculture Economic Research Service (USDA ERC). (2008). Agricultural baseline projections: Global agricultural trade, 2008-2017. Retrieved April 14, 2008 from http://www.ers.usda.gov/Briefing/Baseline/trade.htm.

Vesterby, M., \& Krupa, K. S. (1997). Major Uses of Land in the United States. U.S. Department of Agriculture, Statistical Bulletin, 973. Retrieved October 2, 2006 from http://usda.mannlib.cornell.edu/usda/nass/SB973/sb973.pdf.

Webb, C. W. (1995). Agricultural knowledge of entering agriculture majors at Potomac State College and West Virginia University. Unpublished master's thesis, West Virginia University, Morgantown, WV.

West Virginia University Extension Service. (1999). About the land-grant system. Retrieved April 6, 2008 from http://www.wvu.edu/ exten/about/land.htm\#what.

Womochil, M. (Ed). (2007a). Looking to the future. FFA Advisors Making a Difference, 15 (8), 1.

Womochil, M. (Ed) (2007b). The state of agricultural education. FFA Advisors Making a Difference, 15 (8), 7-8. 
APPENDICES 


\section{APPENDIX A}

Email Correspondence with West Virginia University First Year Experience Orientation Instructors 


\section{Dear Orientation Course Instructor:}

I am in the process of conducting research on "agricultural awareness and perceptions of freshmen students at West Virginia University." The results of this study will be used to prepare a thesis to partially fulfill the requirements for a Master of Science Degree in Agricultural and Extension Education.

Currently, I have had tremendous support by instructors of a number of University 101 courses and Orientation courses, including Dr. Hillar Klandorf, Resident Faculty Leader for Lyon Tower, and Dr. Stacy Gartin, Professor and Chair, Agricultural and Extension Education, who have allowed me to administer my questionnaire during their scheduled class time.

In order to reach my target population and complete my research project, I need your help. Will you provide me with similar access to the students in your Orientation class(es)? I estimate that I will need approximately 15 minutes during one class session for students to complete the questionnaire. I have found that it works best if I provide the questionnaires, complete with a cover letter including instructions on how to complete the questionnaire, to the instructors who can then administer them at the end of the class, or at their convenience, so as to minimize the amount of "dead time" during class. I can also administer the questionnaires myself during the beginning of class. The questionnaires must be completed by students during the Fall 2007 semester.

Your participation is vital to the success of this research endeavor. I encourage you to contact me with any questions or concerns you might have regarding my research, as well as with an indication of your decision in assisting me. I look forward to working with you on this project. Thank you for your time and consideration!

Sincerely,

Laura L. Pfeifer

Graduate Student 
APPENDIX B

Questionnaire 


\title{
Agricultural Awareness and Perceptions of Freshmen at West Virginia University
}

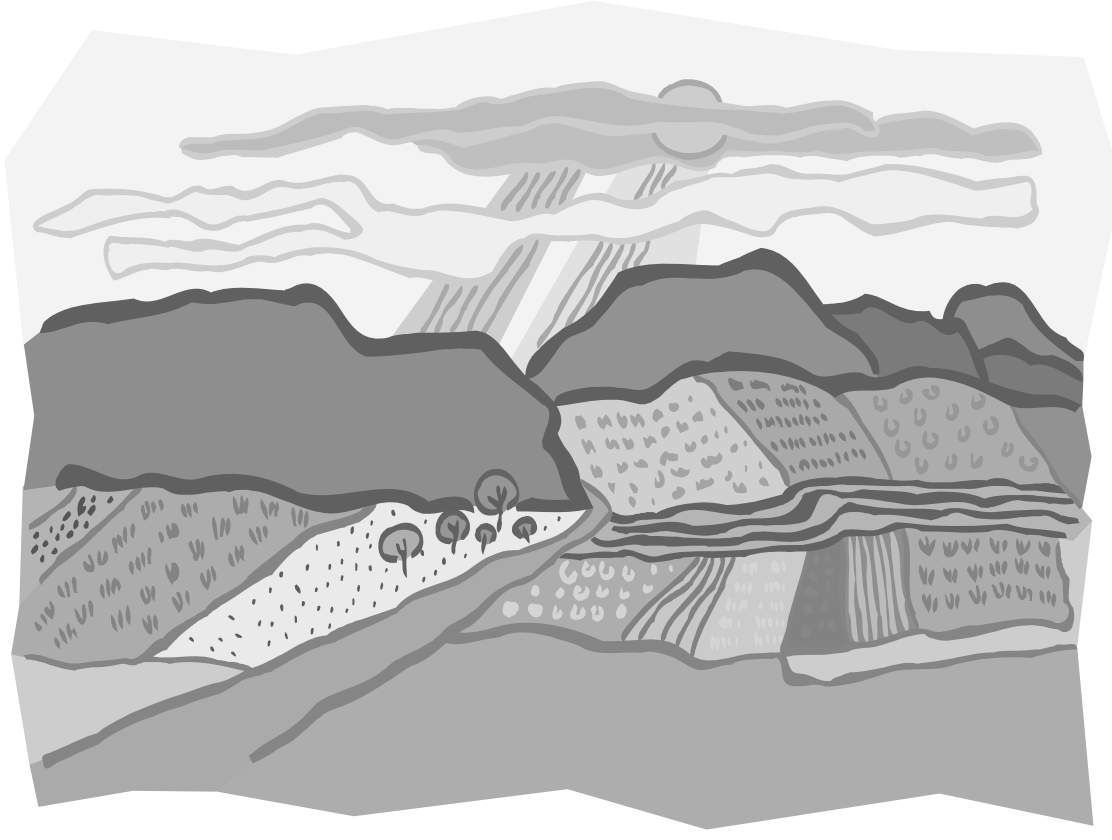

\author{
Laura L. Pfeifer \\ Graduate Student \\ Agricultural and Extension Education \\ Davis College of Agriculture, Forestry, and Consumer Sciences \\ West Virginia University \\ Morgantown, WV 26506
}




\section{Agricultural Awareness and Perceptions of Freshmen at West Virginia University}

Instructions: Read each of the following statements and indicate your response by circling "T" if you think the statement is TRUE or circling " $F$ " if you think the statement is FALSE. If you are sure your response is correct, circle "S." If you are unsure about your response, circle "U." You should have two responses for each statement.

Example: Read the following statement in the grey box. Assume that you know that U.S. farms are larger than European farms and you are certain of your answer. Circle "F" for your answer and " $\mathrm{S}$ " for your confidence level.

U.S. farms are smaller than those in Europe.

$\mathrm{T}$

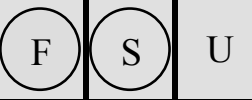

\begin{tabular}{|c|c|c|c|c|}
\hline Statement & $\stackrel{\mathscr{E}}{E}$ & $\frac{\ddot{D}}{\pi}$ & के & \\
\hline 1. There are more farmers in the U.S. than there were 10 years ago. & $\mathrm{T}$ & $\mathrm{F}$ & $\mathrm{S}$ & $\mathrm{U}$ \\
\hline $\begin{array}{l}\text { 2. Less than } 3 \text { percent of the U.S. gross national product is from } \\
\text { agriculture. }\end{array}$ & $\mathrm{T}$ & $\mathrm{F}$ & $\mathrm{S}$ & $\mathrm{U}$ \\
\hline 3. Soil erosion does NOT pollute U.S. lakes and rivers. & $\mathrm{T}$ & $\mathrm{F}$ & $\mathrm{S}$ & $\mathrm{U}$ \\
\hline 4. The use of pesticides has increased the yield of crops. & $\mathrm{T}$ & $\mathrm{F}$ & $\mathrm{S}$ & $\mathrm{U}$ \\
\hline 5. Animal health and nutrition are important to farmers. & $\mathrm{T}$ & $\mathrm{F}$ & $\mathrm{S}$ & $\mathrm{U}$ \\
\hline 6. Food safety is a major concern of the food processing industry. & $\mathrm{T}$ & $\mathrm{F}$ & $\mathrm{S}$ & $\mathrm{U}$ \\
\hline 7. Processing increases the cost of food products. & $\mathrm{T}$ & $\mathrm{F}$ & $\mathrm{S}$ & $\mathrm{U}$ \\
\hline 8. U.S. research has improved farming methods in other countries. & $\mathrm{T}$ & $\mathrm{F}$ & $\mathrm{S}$ & $\mathrm{U}$ \\
\hline 9. One of every five jobs in the U.S. is related to agriculture. & $\mathrm{T}$ & $\mathrm{F}$ & $\mathrm{S}$ & $\mathrm{U}$ \\
\hline 10. Many farmers use tillage practices that conserve the soil. & $\mathrm{T}$ & $\mathrm{F}$ & $\mathrm{S}$ & $\mathrm{U}$ \\
\hline
\end{tabular}




\begin{tabular}{|c|c|c|c|c|}
\hline 11. Plant products are the main source of human foods. & $\mathrm{T}$ & $\mathrm{F}$ & $\mathrm{S}$ & $\mathrm{U}$ \\
\hline 12. Animals can be a valuable source of medical products. & $\mathrm{T}$ & $\mathrm{F}$ & $\mathrm{S}$ & $\mathrm{U}$ \\
\hline 13. Homogenization kills bacteria in milk with heat. & $\mathrm{T}$ & $\mathrm{F}$ & $\mathrm{S}$ & $\mathrm{U}$ \\
\hline 14. The U.S. does not sell its feed grains on the world market. & $\mathrm{T}$ & $\mathrm{F}$ & $\mathrm{S}$ & $\mathrm{U}$ \\
\hline 15. Thousands of people in the world die of starvation each year. & $\mathrm{T}$ & $\mathrm{F}$ & $\mathrm{S}$ & $\mathrm{U}$ \\
\hline 16. Local laws and regulations have little effect on farmers. & $\mathrm{T}$ & $\mathrm{F}$ & $\mathrm{S}$ & $\mathrm{U}$ \\
\hline 17. Farming and wildlife cannot survive in the same geographic area. & $\mathrm{T}$ & $\mathrm{F}$ & $\mathrm{S}$ & $\mathrm{U}$ \\
\hline 18. Biotechnology has increased the pest resistance of plants. & $\mathrm{T}$ & $\mathrm{F}$ & $\mathrm{S}$ & $\mathrm{U}$ \\
\hline 19. Animals eat foodstuffs that cannot be digested by humans. & $\mathrm{T}$ & $\mathrm{F}$ & $\mathrm{S}$ & $\mathrm{U}$ \\
\hline 20. New products have been developed using surplus grains. & $\mathrm{T}$ & $\mathrm{F}$ & $\mathrm{S}$ & $\mathrm{U}$ \\
\hline $\begin{array}{l}\text { 21. Grain exports are usually transported between continents by } \\
\text { airplane. }\end{array}$ & $\mathrm{T}$ & $\mathrm{F}$ & $\mathrm{S}$ & $\mathrm{U}$ \\
\hline 22. The average U.S. farm is larger than 500 acres. & $\mathrm{T}$ & $\mathrm{F}$ & $\mathrm{S}$ & $\mathrm{U}$ \\
\hline 23. U.S. agricultural policies influence food prices in other countries. & $\mathrm{T}$ & $\mathrm{F}$ & $\mathrm{S}$ & $\mathrm{U}$ \\
\hline 24. Animal wastes are used to increase soil fertility. & $\mathrm{T}$ & $\mathrm{F}$ & $\mathrm{S}$ & $\mathrm{U}$ \\
\hline 25. Profits increase as farmers strive for the maximum crop yields. & $\mathrm{T}$ & $\mathrm{F}$ & $\mathrm{S}$ & $\mathrm{U}$ \\
\hline 26. Biotechnology has increased animal production in the U.S. & $\mathrm{T}$ & $\mathrm{F}$ & $\mathrm{S}$ & $\mathrm{U}$ \\
\hline 27. Pasteurization kills bacteria in milk with heat. & $\mathrm{T}$ & $\mathrm{F}$ & $\mathrm{S}$ & $\mathrm{U}$ \\
\hline
\end{tabular}




\begin{tabular}{|l|c|c|c|c|}
\hline $\begin{array}{l}\text { 28. An efficient food distribution system is essential to the agriculture } \\
\text { industry. }\end{array}$ & $\mathrm{T}$ & $\mathrm{F}$ & $\mathrm{S}$ & $\mathrm{U}$ \\
\hline $\begin{array}{l}\text { 29. Several countries depend on U.S. agricultural exports for food and } \\
\text { fiber. }\end{array}$ & $\mathrm{T}$ & $\mathrm{F}$ & $\mathrm{S}$ & $\mathrm{U}$ \\
\hline $\begin{array}{l}\text { 30. Government subsidy payments to farmers are used to stabilize food } \\
\text { prices. }\end{array}$ & $\mathrm{T}$ & $\mathrm{F}$ & $\mathrm{S}$ & $\mathrm{U}$ \\
\hline $\begin{array}{l}\text { 31. Water, soil, and minerals are important in agriculture. } \\
\text { 32. Very little of the grain produced in the U.S. is exported. }\end{array}$ & $\mathrm{T}$ & $\mathrm{F}$ & $\mathrm{S}$ & $\mathrm{U}$ \\
\hline $\begin{array}{l}\text { 33. Hamburger is made from the meat of pigs. } \\
\begin{array}{l}\text { 34. Using grain alcohol for fuel reduces the U.S. dependence on foreign } \\
\text { oil. }\end{array}\end{array}$ & $\mathrm{T}$ & $\mathrm{F}$ & $\mathrm{S}$ & $\mathrm{S}$ \\
\hline $\begin{array}{l}\text { 35. Transportation and storage affects the supply of agricultural } \\
\text { products. }\end{array}$ & $\mathrm{T}$ & $\mathrm{F}$ & $\mathrm{S}$ & $\mathrm{U}$ \\
\hline
\end{tabular}

Instructions: Using the following Likert scale, rate your opinion on each of the following agriculture-related statements. Indicate your opinion by circling the letters that best correspond to your response: SA - Strongly Agree, A - Agree, N - Neutral, D - Disagree, SD - Strongly Disagree.

Example: Read the following statement in the grey box. Assume that you strongly disagree with the statement that 'All farmers live beyond their means.' Circle "SD" to indicate this opinion.

All farmers live beyond their means. 


\begin{tabular}{|c|c|c|c|c|c|}
\hline Statement & 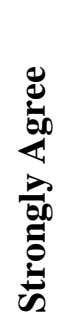 & & 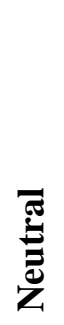 & 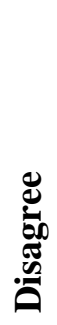 & 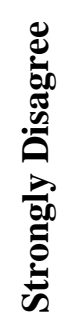 \\
\hline $\begin{array}{l}\text { 36. U.S. citizens spend a higher percent of their income on food } \\
\text { than in other countries. }\end{array}$ & SA & A & $\mathrm{N}$ & $\mathrm{D}$ & $\mathrm{SD}$ \\
\hline $\begin{array}{l}\text { 37. Agriculture employs a large number of people in this } \\
\text { country. }\end{array}$ & SA & A & $\mathrm{N}$ & $\mathrm{D}$ & $\mathrm{SD}$ \\
\hline 38. Pesticides can be used safely when producing food. & SA & A & $\mathrm{N}$ & $\mathrm{D}$ & $\mathrm{SD}$ \\
\hline $\begin{array}{l}\text { 39. Organic production methods are a realistic alternative to } \\
\text { using pesticides. }\end{array}$ & SA & A & $\mathrm{N}$ & $\mathrm{D}$ & $\mathrm{SD}$ \\
\hline $\begin{array}{l}\text { 40. Confinement is an acceptable practice when raising } \\
\text { livestock. }\end{array}$ & SA & A & $\mathrm{N}$ & $\mathrm{D}$ & $\mathrm{SD}$ \\
\hline 41. Consumers prefer processed foods to raw products. & SA & A & $\mathrm{N}$ & $\mathrm{D}$ & $\mathrm{SD}$ \\
\hline $\begin{array}{l}\text { 42. Developing countries need help to be able to store food } \\
\text { safely. }\end{array}$ & SA & A & $\mathrm{N}$ & $\mathrm{D}$ & $\mathrm{SD}$ \\
\hline $\begin{array}{l}\text { 43. People are moving away from rural areas due to changes in } \\
\text { agriculture. }\end{array}$ & SA & A & $\mathrm{N}$ & $\mathrm{D}$ & $\mathrm{SD}$ \\
\hline 44. Farmers earn too much money. & SA & $\mathrm{A}$ & $\mathrm{N}$ & $\mathrm{D}$ & SD \\
\hline 45. Not all land is suitable for farming. & SA & A & $\mathrm{N}$ & $\mathrm{D}$ & SD \\
\hline $\begin{array}{l}\text { 46. Biotechnology has increased the yield of crops in developing } \\
\text { countries. }\end{array}$ & SA & A & $\mathrm{N}$ & $\mathrm{D}$ & $\mathrm{SD}$ \\
\hline 47. Farmers take good care of their animals. & SA & A & $\mathrm{N}$ & $\mathrm{D}$ & SD \\
\hline 48. Processing adds value to farm products. & SA & A & $\mathrm{N}$ & $\mathrm{D}$ & $\mathrm{SD}$ \\
\hline $\begin{array}{l}\text { 49. Farmers should develop new and innovative marketing } \\
\text { strategies. }\end{array}$ & SA & A & $\mathrm{N}$ & $\mathrm{D}$ & $\mathrm{SD}$ \\
\hline $\begin{array}{l}\text { 50. A strong agricultural industry is more important than military } \\
\text { power. }\end{array}$ & SA & A & $\mathrm{N}$ & $\mathrm{D}$ & SD \\
\hline
\end{tabular}




\begin{tabular}{|c|c|c|c|c|c|}
\hline 51. Agricultural exports help to reduce the U.S. trade deficit. & SA & A & $\mathrm{N}$ & $\mathrm{D}$ & SD \\
\hline 52. Agricultural practices are harmful to the environment. & SA & A & $\mathrm{N}$ & $\mathrm{D}$ & SD \\
\hline 53. Raising hybrid plants results in higher yields. & SA & A & $\mathrm{N}$ & $\mathrm{D}$ & $\mathrm{SD}$ \\
\hline $\begin{array}{l}\text { 54. Farmers are concerned about the humane treatment of } \\
\text { animals. }\end{array}$ & SA & A & $\mathrm{N}$ & $\mathrm{D}$ & $\mathrm{SD}$ \\
\hline 55. Processing food products is a benefit to consumers. & SA & A & $\mathrm{N}$ & $\mathrm{D}$ & SD \\
\hline $\begin{array}{l}\text { 56. The U.S. should allow free trade with other countries for } \\
\text { food products. }\end{array}$ & SA & A & $\mathrm{N}$ & $\mathrm{D}$ & $\mathrm{SD}$ \\
\hline $\begin{array}{l}\text { 57. The world food supply has increased as a result of improved } \\
\text { technology. }\end{array}$ & SA & A & $\mathrm{N}$ & $\mathrm{D}$ & SD \\
\hline $\begin{array}{l}\text { 58. The U.S. needs a steady supply of food and fiber products to } \\
\text { remain strong. }\end{array}$ & SA & A & $\mathrm{N}$ & $\mathrm{D}$ & SD \\
\hline 59. Only organic methods should be used to produce food. & SA & A & $\mathrm{N}$ & $\mathrm{D}$ & SD \\
\hline 60. Farmers should NOT use chemicals in crop production. & SA & A & $\mathrm{N}$ & $\mathrm{D}$ & $\mathrm{SD}$ \\
\hline 61. Animals have the same rights as people. & SA & A & $\mathrm{N}$ & $\mathrm{D}$ & $\mathrm{SD}$ \\
\hline $\begin{array}{l}\text { 62. Processing adds more to the cost of food than the raw } \\
\text { product. }\end{array}$ & SA & A & $\mathrm{N}$ & $\mathrm{D}$ & $\mathrm{SD}$ \\
\hline 63. Farmers have no control over food prices. & SA & A & $\mathrm{N}$ & $\mathrm{D}$ & SD \\
\hline $\begin{array}{l}\text { 64. Developing countries lack the ability to produce enough } \\
\text { food. }\end{array}$ & SA & A & $\mathrm{N}$ & $\mathrm{D}$ & SD \\
\hline 65. The government should exert more control over farming. & SA & A & $\mathrm{N}$ & $\mathrm{D}$ & SD \\
\hline
\end{tabular}




\begin{tabular}{|l|c|c|c|c|c|}
\hline 66. Agriculture is the greatest polluter of our water supplies. & SA & A & N & D & SD \\
\hline 67. Agriculture has become too mechanized. & SA & A & N & D & SD \\
\hline 68. Animals should NOT be used for food. & SA & A & N & D & SD \\
\hline $\begin{array}{l}\text { 69. Farm grains are becoming an important energy source in the } \\
\text { U.S. }\end{array}$ & SA & A & N & D & SD \\
\hline $\begin{array}{l}\text { 70. Developing countries need help in distributing food among } \\
\text { needy people. }\end{array}$ & SA & A & N & D & SD \\
\hline
\end{tabular}

Instructions: Please read each question completely and place a check mark in front of the appropriate response or provide an answer where indicated.

71. What is your gender?
a. Male

b. Female

72. What is your age?
a. $<18$ years
b. $18-21$ years
c. $22-25$ years
d. $>26$ years 
73. How do you define your ethnic group:

a. American Indian or Alaskan Native

b. Asian or Pacific Islander

c. Black

d. Hispanic

e. White

f. Other (please specify)

74. What is your home state/country?

75. Are you a traditional college student (directly entering college after graduating from high school)?

a. Yes

b. No

76. What is your rank?

a. First Semester Freshman

b. Freshman

c. Sophomore

d. Junior

e. Senior

f. Graduate Student

g. Other (please specify)

77. What is your major?

78. Where did you grow up?

a. On a farm or ranch

b. In a city

c. In a suburb

d. In a rural area, not on a farm

79. Have you ever worked on a farm or ranch?

a. Yes (please specify type)

b. No

80. Have you ever worked in an agricultural business?

a. Yes (please specify type)

b. No 
81. Do you have relatives who live or work on a farm or ranch?

a. Yes

b. No

82. Do you have relatives who work in an agricultural business?
a. Yes

b. No

83. Did you take agricultural courses in high school?
a. Yes (Skip to question 85)

b. No (Proceed to question 84)

84. Did your high school offer courses in agricultural education?
a. Yes
b. No

85. Were you a member of FFA?

a. Yes

b. No

86. Were you a member of $4-\mathrm{H}$ ?
a. Yes
b. No

87. Were you a member of any other agricultural organization(s)?

a. Yes (please specify)

b. No

88. What types of agriculture-related organizations are available to you in your home community? (Check all that apply.)

a. 4-H

b. Ag Cooperative

c. Breed Associations

d. Farm Bureau

e. FFA

f. Grange

g. National Beef Council

h. National Rifle Association

i. None

j. Other (please specify):

k. Don't Know 
89. Since entering college at West Virginia University, have you become involved in any agricultural organization(s)?

a. Yes (please specify)

b. No

90. A Land Grant University is characterized by an institution whose mission is to provide instruction primarily in:

a. research and development of sustainable and environmentally-friendly bio-based energy alternatives.

b. agriculture, military tactics, the mechanic arts, and cooperative extension as well as classical studies.

c. urban affairs and public policy.

d. scientific research, education, training, and extension projects geared toward the conservation and practical use of U.S. coasts, the Great Lakes and other marine areas.

91. Are you aware that West Virginia University is a Land Grant University?

a. Yes (please specify how):

b. No

92. Are you aware that West Virginia University owns and operates several farms?

a. Yes (please specify how):

b. No

93. Are you aware that West Virginia University is not the only Land Grant University in West Virginia?

a. Yes [please name other(s)]:

b. No 


\section{Comments:}

\section{Thank you for taking the time to complete this questionnaire!}

If you have any questions regarding the questionnaire, please contact me at: lpfeifer@mix.wvu.edu. 
APPENDIX C

Cover Letter to Questionnaire 
October 29, 2007

Dear West Virginia University Student:

Agriculture is America's number one industry and is truly an essential element to your survival. Because the average citizen is further removed from the agricultural lifestyle than ever before, we often take for granted the impact that agriculture has on us. However, when it comes down to it, from the clothes you wear and the food you eat to your home and vehicle, the number of areas where agriculture reaches is virtually limitless. Because agriculture plays such an important role in everyone's day-to-day lives, it is essential that the average citizen have an understanding of the agricultural industry and appreciate the effects various agricultural practices and policies have on their daily lives.

The purpose of this research study is to determine the level of knowledge of agriculture possessed by incoming freshmen at West Virginia University. The results of this study will be used to prepare a thesis to partially fulfill the requirements for a Master of Science Degree in Agricultural and Extension Education. An awareness of how knowledgeable students are about agriculture will enhance the instruction of agriculture-related topics at the elementary, middle, and high school levels.

Your participation in this research study is completely voluntary and all information you provide will be held as confidential as possible. Your completion of the questionnaire is critical to the success of the study and should only take approximately ten minutes to complete. If you completed this questionnaire in another class, you do not need to fill it out it again. Please feel free to skip any questions you do not feel comfortable answering. The results from the questionnaire will be reported in a summary format and individual responses will not be identifiable.

We are considering a follow-up to our initial research efforts. Should you desire to participate in this follow-up study, please provide your name and contact information on the removable insert found at the back of the questionnaire. Please remove the insert and return it separately to maintain the confidentiality of your responses. Please place the questionnaire in the box provided and the insert in the envelope provided.

Thank you in advance for your assistance with this research effort. We sincerely appreciate your time and effort.

Sincerely,

Laura L. Pfeifer

Graduate Student
Harry N. Boone, Jr., Ph.D

Associate Professor 


\section{APPENDIX D}

\section{Follow-Up Study Page}


We are considering a follow-up to our initial research efforts. Should you desire to participate in this follow-up study, please provide your name and contact information in the space provided below. Please remove this insert and return it separately to maintain the confidentiality of your responses.

Name:

Permanent Address:

Primary Email Address:

Primary Phone Number:

Comments: 


\section{APPENDIX E}

“Other” Ethnicities of Respondents 
Other Ethnicities

\author{
Cape Verdian \\ Chilean \\ European \\ Middle Eastern, small amounts of Native Americans \\ Spanish, white? \\ Uzbek/Turkish
}


APPENDIX F

College Majors of Respondents 


\begin{tabular}{|c|c|c|}
\hline A\&VS & Animal and Nutritional & Biochemistry \\
\hline A\&VS & Sciences & Biochemistry \\
\hline Accounting & Animal and Nutritional & Biochemistry \\
\hline Accounting & Sciences & Biochemistry \\
\hline $\mathrm{ACE}$ & Animal and Nutritional & Biochemistry \\
\hline Advertising & Sciences & Biochemistry \\
\hline Advertising & Animal and Nutritional & Biochemistry \\
\hline Ag Business & Sciences & Biochemistry \\
\hline Ag. Business & Animal and Nutritional & Biochemistry \\
\hline Management & Sciences & Biochemistry \\
\hline Ag-Business & Animal and Nutritional & Biochemistry \\
\hline Agricultural and & Sciences & Biochemistry \\
\hline Extension Education & Animal and vet sciences & Biochemistry \\
\hline Agricultural and & Animal and vet sciences & Biochemistry \\
\hline Extension Education & Animal and Veterinary & Biochemistry \\
\hline Agricultural and & Science & Biochemistry \\
\hline Extension Education & Animal and Veterinary & Biochemistry \\
\hline Agricultural and & Science & Biochemistry \\
\hline Extension Education and & Animal Sci. & Biochemistry \\
\hline Horticulture & Animal Science & Biochemistry \\
\hline Agricultural Education & Animal Science & Biochemistry-Biology \\
\hline Agricultural Education & Animal Science & Biochmistry \\
\hline Agricultural Education & Animal Sciences & Biochmistry and Int. \\
\hline Agricultural Education & Animal Vet.Sciences & Studies \\
\hline Agricultural Education & Archeology & Biology \\
\hline Agricultural Education & Art & Biology \\
\hline Agricultural & Art Ed/Screenprinting & Biology \\
\hline Education/International & Athletic Training & Biology \\
\hline Studies Minor & Athletic Training & Biology \\
\hline Agricultural Extension & Athletic Training & Biology \\
\hline and Education & AVS & Biology \\
\hline Agriculture Education & Bachelor of Fine Arts & Biology \\
\hline Agriculture Education & BFA Acting & Biology \\
\hline Animal \& Nutritional & Performances & Biology \\
\hline Science & Biochemistry & Biology and \\
\hline Animal \& Nutritional & Biochemistry & Mathematics \\
\hline Science & Biochemistry & Biology/Chemistry \\
\hline Animal \& Nutritional & Biochemistry & $\mathrm{BM} \mathrm{w} / \mathrm{IR}$ \\
\hline Science & Biochemistry & Broadcast Journalism \\
\hline Animal \& Nutritional & Biochemistry & Business \\
\hline Science & Biochemistry & Business \\
\hline Animal \& Nutritional & Biochemistry & Business \\
\hline Science & Biochemistry & Business \\
\hline Animal \& Vet Science & Biochemistry & Business \\
\hline Animal \& Vet Science & Biochemistry & Business \\
\hline Animal \& Vet Sciences & Biochemistry & Business \\
\hline
\end{tabular}




Business
Business
Business
Business
Business
Business
Business
Business
Business
Business
Business
Business
Business
Business
Business - Marketing
Business and Economics
Business and Economics
Business and Economics
Business and Economics
Business and Finance
Business Management
Business Management
Business Management
Business Management
Business Management
Business/Economics
Business/MIS.
Chemistry
Chemistry
Child
Development/Family
Studies
Child
Development/Family
Studies
Communications
Communications
Computer Science
Criminal Justice
Criminology
Criminology
Criminology
Criminology
Criminology
Criminology
Criminology

Criminology

Criminology

Criminology and

Investigations

Criminology and

nvestigative Science

Criminology and

nvestigative Science

Criminology and

nvestigative Science

Dietetics

Economics

Economics

Education

Education

Education

Education

Elementary Ed.

Elementary Ed.

Elementary Ed.

Elementary Ed.

Elementary Ed.

Elementary Ed.

Elementary Ed.

Elementary Edu.

Engineering

Engineering

English

English

English

English

Exercise Physiology

Exercise Physiology

Exercise Physiology

Exercise Physiology

Exercise Physiology

Exercise Physiology

Exercise Physiology

Exercise Physiology

Exercise Physiology

Exercise

Physiology/Nutrition

Fashion Merchandising

Finance

Fincance

Foreign Languages
Forensic and

Investigative Science

Forensic Science

Forensic science

Forensic science

Forensic science

Forensic science

Forensic science

Forensics

Forensics

Forensics

Forensics

Forensics

Forensics

Forensics

Forensics

G.S.

Gen. Engineering

General

General Studies

General Studies

General Studies

General Studies

General Studies

General Studies

General Studies

Geography

Geology

Geology

Graphic Design

Graphic Design

Graphic Design

History

History

History

History

history

$\mathrm{HN} \& \mathrm{~F}$

HNF

human nutrition

Human Nutrition and

Foods

Human Nutrition and

Foods

Human Nutrition and Foods 


\begin{tabular}{|c|c|c|}
\hline Human Nutrition and & Music Education & Pre-Business and \\
\hline Foods & Non Declared & Economics \\
\hline Human Nutrition and & Nursing & Pre-Business \\
\hline Foods & Nursing & Management \\
\hline Human Nutrition and & Nursing & Pre-Business \\
\hline Foods & Nursing & Management \\
\hline Human Nutrition and & Nursing & Pre-Communications \\
\hline Foods & Nursing & Pre-Education \\
\hline Interior Design & Nutrition & Pre-education switching \\
\hline International Studies & Nutrition & to social work \\
\hline International Studies & Occupational Therapy & Pre-Elementary \\
\hline International Studies & Physical Education & Pre-English \\
\hline Journalism & Physical Education & Pre-finance \\
\hline Journalism & Physical Education & Pre-Forensic Science \\
\hline Landscape Architecture & Political Science & Pre-Forensics \\
\hline Landscape Architecture & Political Science & Pre-Forensics \\
\hline Landscape Architecture & Political Science & Pre-Forensics \\
\hline Landscape Architecture & Political Science & Pre-Forensics \\
\hline Landscape Architecture & Political Science & Pre-Journalism \\
\hline Landscape Architecture & Political Science & Pre-Marketing \\
\hline Landscape Architecture & Political Science & Pre-Nursing \\
\hline Landscape Architecture & Political Science & Pre-Pharmacy \\
\hline Landscape Architecture & Political Science & Pre-Pharmacy \\
\hline Landscape Architecture & Pre athletic training & Pre-Pharmacy \\
\hline Landscape Architecture & Pre Busa. & Pre-Pharmacy \\
\hline Management & Pre communications & Pre-Pharmacy \\
\hline Management Info & Pre Nursing & Pre-Pharmacy \\
\hline Systems & Pre OT & Pre-Pharmacy \\
\hline Marketing & Pre-Accounting & Pre-secondary \\
\hline Marketing & Pre-athletic training & educ/interdepartmental \\
\hline Marketing & Pre-athletic training & studies \\
\hline Marketing & Pre-athletic training & Pre-secondary \\
\hline Marketing & Pre-Bio & education/Foreign \\
\hline Marketing & Pre-Biochemistry & Language (French \& \\
\hline Marketing & Pre-Biochemistry & Spanish) \\
\hline MIS & Pre-Biochemistry & Pre-Social Work \\
\hline MIS & Pre-Biology & Pre-Sociology \& \\
\hline Music Ed & Pre-Biology & Anthropology \\
\hline Music Ed & Pre-Biology & Pre-Speech Pathology \\
\hline Music Ed & Pre-Biology & and Audiology \\
\hline Music Ed & Pre-Biology & Pre-Sport Management \\
\hline Music Ed & Pre-Biology & and Business \\
\hline Music Ed & Pre-Business & Pre-Vet \\
\hline Music Education & Pre-Business & Pre-Vet \\
\hline Music Education & Pre-Business & Pre-vet (animal science) \\
\hline Music Education & & Psych \\
\hline
\end{tabular}


Psychology

Psychology

Psychology

Psychology

Psychology and

Exercise Physiology

Public Relations

Public Relations

Public Relations

Public Relations

Secondary Education

Secondary Education

Secondary Education

Secondary Education

Social Studies

Secondary

Education/English

Secondary

Education/Math

Secondary Education-

English
Secondary Education-

English

Social Work

Sociology

Sociology and

Anthropology

Speech Pathology and

Audiology

Speech Pathology and

Audiology

Speech Pathology and

Audiology

Sport and Exercise

Psych

Sport Management

Sports Management

Sports Management

Sports Management

Sports Management

Sports Management

Sports Management
Sports Management Sports Management Textile, Apparel, and Merchandising Textile, Apparel, and Merchandising

Theater

Theater Tech, Design

Theater/Dance

Undecided

Undecided

Undecided

Undecided

Undecided

Undecided

Undecided

Underwater Basket

Weaving

Voice Performance

Wildlife and Fisheries 
APPENDIX G

Agriculture-Related Work Experience of Respondents 


\begin{tabular}{|c|c|c|}
\hline Angus farm & farm & livestock and \\
\hline Angus farm & Farm & agricultural \\
\hline Apple and feed corn and & Farm & Livestock Farm \\
\hline hay & Farm & local/small \\
\hline Beef & Farm & milked my grandparents \\
\hline Beef and dairy, horse & farm & cows \\
\hline Beef Cattle & farm & Mountain Farms \\
\hline Beef cattle operation & farm & (Angus) Pendalton, WV \\
\hline Beef operation, dairy & Farm in North Carolina & My farm \\
\hline farm, hog operation, & (food and lifestock) & My grandparents keep \\
\hline horses, chickens, ets. & farm, produce, animal & horses, chickens, and \\
\hline Beef, Sheep & products & pigs \\
\hline big farm & farm/garden nursary & my grandparents own a \\
\hline Cattle & Grain + Dairy farm & dairy farm \\
\hline Cattle & Grain wheat, christmas & Near my house for \\
\hline Cattle and tobbaco & tree farm & community service \\
\hline Cattle Farm & Greenhouse and farm & Next to b: (I did help a \\
\hline Cattle farm & (corn) & friend with hay several \\
\hline cattle, some crop & Hay and corn & times though) \\
\hline production & Hayfield & Nursery, Greenhouse, \\
\hline Christmas tree and horse & Helped roll hay & Vegetable Farm \\
\hline Corn, beans & Herding Cattle & Packing beef \\
\hline cotton, sobean, sweet & home & personal horse farm \\
\hline potatoes, that sort of & horse & Pig Farm \\
\hline farm & Horse & Plants/crops \\
\hline Cow Farm & horse & Produce farm \\
\hline Cows, home garden, & horse and livestock & Produce farm \\
\hline horses & horse farm & Produce growing \\
\hline Cows, horses, chickens, & Horse Farm & Pumpkin farm and \\
\hline pigs & Horse farm & family farm \\
\hline Dad's bef cow farm & Horse farm and cabage & Q79A \\
\hline Dairy & Horse Rance & raised beef cows \\
\hline Dairy & Horse ranch & recreationally \\
\hline Dairy & horses & Sheep and cattle (show \\
\hline Dairy farm & Horses & animals) \\
\hline Dairy farm & horses & show cattle, club lamb \\
\hline Dairy farm & I grew up on one, & operation \\
\hline Dairy farm & chores, feeding, bailing & Small Beef Farm \\
\hline Dairy WVU & hay & small farm \\
\hline family & I've help a friend feed & small truck farm \\
\hline Family Farm & the animals and do other & Stressful ones \\
\hline Family Farm & stuff & Tree Farm \\
\hline Family Farm & Kidwell farm, volunteer & Vineyard Beef \\
\hline Family Farm & Large farm - cattle, pigs, & Burger King \\
\hline Family Farm & chickens & Cedar Lakes - Landscape \\
\hline Family farm & & $\begin{array}{l}\text { Mang. } \\
\text { Christmas tree numnkin }\end{array}$ \\
\hline
\end{tabular}


Club lamb operation

Dairy

Delaware Dept. of Ag

Family Farm

Family Farm

family owned club lamb

flock

farm

Farm

Feed and Seed store

Feed Angus cows

for my grandfather

Fruit market

Garden nursary

garden/landscaping

company

grain

Greenhouse

Greenhouse

Greenhouse

Greenhouse and farm

(corn)

Hay and cabage

Landscaping

Market Place

My dad owns a meat

packing plant. They

don't slaughter or

butcher. They're more

like a middleman.

Nursery

on farm

Packing Plant, Dodge

City Kansas

Plant Nursery

Proudfoot Farm

Q80A

Raised Cattle

Restraunt

Selling produce, trees, pumpkins

Smaall Animal Practices

Tree farm

Tree Farm

Veterinary

Vineyard
WVDA

Young and Stout 


\section{APPENDIX H}

Agriculture-Related Organizations Available to Respondents in their Home Communities 
Ag Marketing

Boy Scouts

Fair Board, Extension Service

Probably all I'm from Lancaster 
APPENDIX I

Respondent's Membership in Agriculture-Related Organizations 
American Maine-Anjou Association

PA state Livestock Judging Team

PA Club Livestock Association,

Jr. Beef Producers

Appaloosa Horse Club

Youth Fair Board

Block \& Bridle

Block \& Bridle

Collegiate Farm Bureau, \& Dairy Science Club

Farm Bureau, NRA, Fairboard

Farm Bureau, Young Farmers, Ag-Expo

FFA, 4-H

Frederick Co. Young Farmers

Junior Livestock Association

National Rifle Association

PA farm bureau, Maine-Anjou Association

Q87A

Sigma Alpha

Young Farmers, Breed Associations

Young Farmers, Farm Bureau, Mardel Watermelon Association 


\title{
APPENDIX J
}

Respondent's Membership in Agriculture-Related Organizations at West Virginia

\author{
University
}


Block and Bridle

Block and Bridle and Sigma Alpha

Block and Bridle and Sigma Alpha

Block and Bridle Club

Block and Bridle, FFA, Farm Bureau

Collegiate 4-H

Collegiate 4-H

Collegiate FFA

Collegiate FFA

Collegiate FFA

Dairy Science, Block and Bridle

Farm Bureau, Dairy science club

Farm Bureau, Dairy Club, SA

FFA, Block and Bridle

FFA, Block and Bridle

FFA, Block and Bridle, 4-H

FFA, Sigma Alpha, and 4-H

I have joined more

If AGBI class counts than yes, if not, no.

Sigma Alpha Sorority

SSLA

Wildlife \& Fisheries \& Sigma Alpha 


\section{APPENDIX K}

Knowledge of West Virginia University's Status as a Land Grant University 
8th grade WV history

A book

A guy told me years ago

A teacher

A\&VS

Ag Extension Class

Ag teacher told me

AVS 105 class

AVS 105 papers

Class

Class

Class

Class

Class

Class

class

class

Classes, Scholarships

Common knowledge

Common knowledge

Common knowledge

Convocation

Ecampus link

Extension Program in class

Family

Family has talked about it

From A\&VS 105

from high school class

Gov gave WV money to start a

university

Guest speaker in class

heard it said several times

Hillar Klandorf told us

History class

History class

Honors 199

I found out in class.

I heard about it

I heard during orientation

I learned this in 4-H

I live by the school

I went to president inuagaration

It was established as WV agriculture

college

It's in he brocure

Jepardy
Learned in AVS 105

learned it

Lincoln

Mom

money is given to towards research

My parents went there

Orientation

Orientation

Orientation

parents

Political science class

prof told me

Professor once told the class

Professor told me so

professors

question 90

RA told me

read it in encyclopedia

says so in my university 101 textbook

School, WV Studies

Social Studies

Stacy Gartin

Teacher

this class

this class

through class

through my AVS class

Through this class

Told at orientation

univ 101

Univ. 101 It was given as an agricultural

school

University 101

University 101

University 101

university 101

University 101

University 101

University 101

University 101

University 101

University 101

University 101

University 101

University 101

University 101 class 
Via wikipedia/university 101 handbook

Was told when I came here

We had a speaker come to this class

Word of Mouth

WV studies in middle school 


\section{APPENDIX L}

Knowledge of West Virginia University's Status of Owning and Operating Several Farms 
A\&VS

A\&VS 251

Ag Bio 199

$\mathrm{Ag}$ Bio trip to one of WVU's farms

Been there

been to a couple

Been to a WVU farm.

Been to some of them

Biochem 199

Bonnie Fischer told me

Campus map/familiar with area

Class

Class

Class

Class

class

Classes, general

Common knowledge

Common knowledge

Common knowledge

Cousin worked on one

Dairy

Dairy club

Desire to work in them.

Drive by them

drove by them

Drove past some of them

Drove past them

Field Trip in Orientation Biochem

fieldtrip

flyers

forget how, just did

friend

Friend works @ one for her major

friends

Friends

Golden Horseshoe studying

grew up in WV. Just knew

Have a friend who is involved

Have a lab at animal and vet science

farm

have seen them

heading to 68 , apples for sale

I am from Morgantown, I just know

I am from Morgantown, I see them

I am now
I do not know how

I drive by them

I drive past one of them every day

I have a lab at the farm A\&VS 251

I have been there during SAE contests

I have been to the farm

I have driven by the WVU farm

I have had the pleasure of working on

them

I have seen the farms

I have seen them

I heard about it.

I live by them

I live in Morgantown

I live near one

I lived by one

I pass by it everyday

I saw them

I saw them driving around

I see the signs

I visited one in this class

I was at a farm on this campus

I work on one

I'm from Morgantown

It's for the animal/vet science program

along with any other farming/animal

care program

I've been there

I've been there

I've been to one

I've been to one with a friend

I've been to them

I've driven by them.

I've seen one. I didn't know about the others.

I've seen them

I've seen them

just a guess

just heard from a teacher

just knew

Just know/everybody does

labs

Live near one

Looking outside

My english class

My friend Blain Rice works there 
My friend is majoring in vet science

my friends got lost finding towers

my professors

My roommate

NA

one is in Reedsville, the county where I

live

orientation info

Out in Suncrest

Passed them by when driving

professor once told the class

Professor told us

Professors

relatives in Ag classes here

Saw on a map

saw them on the road

Seeing them around town

Seen them

Seen them

Signs

The animal farm and organic farm

There are many farms here.

This class

through this class

told at orientation

Trips to the farm

University 101

University 101

Visit them in Biochemistry class

Visited recently

Visited the farms

WVU Farm? 
APPENDIX M

Knowledge of Other Land Grant University in West Virginia 
can't remember

Don't know specifically

Don't remember

Fairmont, West Virginia State

I just assumed there were others.

Idk

No recollection of which ones

Potomac state, Biotech

Potomac State?

PSC

PSU, MD

There is one more in or near Charleston

West Virginia College in Charleston

West Virginia State

West Virginia State

West Virginia State

West Virginia State University

West Virginia State University

West Virginia State University 
APPENDIX N

Comments 


\section{DON'T EAT MEAT!}

I learned a lot.

I love plants!

Question 34 is highly ambiguous and no solid data supports claims one way or the other as current (and any foreseeable future) methods of production have negative Eroei (energy returned on energy invested), meaning it is a net loss of energy and far less viable than other biofuels (ie biodiesel).

This here's farm country.

This survey was pretty interesting, and I actually learned some things from it.

This was cool, but long

This was very unnecessary. 
VITA

November 24, 1983 Born: Pittsburgh, Pennsylvania

June, 2002

Graduated McGuffey High School, Claysville, Pennsylvania.

May, 2006

Bachelor of Science in Animal and Veterinary Sciences, West

Virginia University.

May, 2008

Master of Science in Agricultural and Extension Education, West

Virginia University. 